\title{
Estudo de atuação e promoção dos recursos culturais, naturais e paisagísticos na Cova do Vapor
}




\section{EQUIPA DE INVESTIGAÇÃO}

CEACT/UAL - Centro de Estudos de Arquitetura, Cidade e Território da Universidade Autónoma de Lisboa:

Filipa Ramalhete

Ricardo Lima

Sérgio Silva

\section{COLABORAÇÃO}

Patrícia Silva (Câmara Municipal de Almada-DIACS)

Francisco Silva (CAA - Centro de Arqueologia de Almada)

Daniela Rato (bolseira de investigação da FCUL - Faculdade de Ciências de Universidade de Lisboa e doutoranda no ICS - Instituto de Ciências Sociais)

Gonçalo Folgado (Locals)

Juan Brunetti (estagiário na EDA, no âmbito do Master of Science in landscape architecture na Technische Universität Dresden)

\section{Realização de inquéritos}

Lenildo Malenga

Ricardo Ramalho

Vladimir Ngala

\section{EQUIPA PROJETO TRANSFORMAR+}

Associação EDA - Ensaios e Diálogos

Amália Buisson

Dolores Papa

\section{PARCEIROS PROJETO TRANSFORMAR+}

Associação de Moradores da Cova do Vapor.

Associação Margem de Coragem

DOI

https://doi.org/10.26619/UAL-CEACT/WP012019 
ÍNDICE

1. Introdução 4

2. Caraterização da área de estudo 6

2.1 Enquadramento sociogeográfico 6

$\begin{array}{ll}2.2 \text { Enquadramento histórico } & 11\end{array}$

2.2.1 A Cova do Vapor na Imprensa 13

2.2.2 A ocupação urbana da Cova do Vapor 16

$\begin{array}{ll}\text { 2.2.3 A vocação balnear da Cova do Vapor } & 17\end{array}$

2.3 Enquadramento geomorfológico e dinâmica sedimentar 18

2.3.1 Enquadramento geomorfológico 18

2.3.2 A evolução da linha de costa no extremo NW do concelho de Almada $\quad 20$

$\begin{array}{ll}2.3 .3 \text { A tendência futura } & 23\end{array}$

2.4 Enquadramento ecológico e dinâmica dunar 25

2.4.1 Valores naturais 25

2.4.2 Os sistemas praia-duna e os serviços ambientais $\quad 27$

2.4.3 Flora e vegetação 28

$\begin{array}{ll}2.4 .4 \text { Riscos e vulnerabilidade } & 30\end{array}$

$\begin{array}{ll}2.5 \text { Enquadramento legislativo } & 33\end{array}$

2.5.1 Instrumentos de Gestão do Território em vigor 33

2.6 Enquadramento urbanístico 40

2.7 Estudos e projetos sobre a Cova do Vapor 49

2.7.1 Estudos realizados sobre a Cova do Vapor $\quad 49$

2.7.2 Projetos com a comunidade local para a proteção do litoral 50

3. Apresentação e análise de dados do trabalho de campo 52

3.1 Inquéritos aos utilizadores da praia 52

3.2 Sessão de sensibilização e participação $\quad 59$

4. Análise e discussão da situação de referência 61

5. Propostas 65

$\begin{array}{lr}\text { Bibliografia } & 69\end{array}$

$\begin{array}{ll}\text { Anexos } & 73\end{array}$ 


\section{ÍNDICE DE MAPAS}

$\begin{array}{ll}\text { Mapa } 1 \text { - Enquadramento da área de estudo } & 7\end{array}$

Mapa 2 - Área de estudo $\quad 8$

Mapa 3 - Faixa de salvaguarda ao galgamento e inundação costeira 36

Mapa 4 - Faixa de salvaguarda à erosão costeira 37

Mapa 5-Rede viária e estacionamento 41

Mapa 6-Mobilidade e acessibilidade $\quad 45$

Mapa 7 - Acesso à praia $\quad 46$

Mapa 8 - Áreas de exposição ao galgamento e erosão 62

Mapa 9-Cenário futuro $\quad 66$

\section{ÍNDICE DE FIGURAS}

Figura 1 - Panorâmica da Cova do Vapor 11

Figura 2 - Evolução do território da Cova do Vapor (1815-2019) 12

Figura 3 - Localização dos bancos arenosos no estuário do Tejo 20

Figura 4 - Evolução da linha de costa entre 1947 e 1980

Figura 5 - Evolução da linha de costa no intervalo temporal 1958-2010 23

Figura 6 - Divisão da zona costeira em tipos de litoral 24

Figura 7 - 0 borrelho-de-coleira-interrompida (Charadrius alexandrinus)

Figura 8 - Biodiversidade e cobertura relativa de cada espécie no sistema dunar da Praia da Cova do Vapor $\quad 29$

Figura 9 - Índice de Vulnerabilidade Costeira para as praias da Cova do Vapor $\quad 31$

Figura 10 - Vista da Avenida António Martins Correia 42

Figura 11 - Vista do estacionamento junto à praia 43

Figura 12 - Acesso à praia - local de intervenção do in situ/ 47

Figura 13-Acesso à praia após o in situ/ $\quad 47$

Figura 14 - Vista do pontão e Farol do Bugio 48

Figura 15 - Soma das avaliações (1 a 5) da Primeira Praia e

Figura 16 - Soma da predisposição para novos hábitos (1 a 5) na Primeira

Praia e Praia da Cova do Vapor, por categoria e por praia 57

\section{ÍNDICE DE TABELAS}

Tabela 1 - Síntese das principais caraterísticas geográficas da Cova do Vapor

Tabela 2 - Caraterização do Índice de Vulnerabilidade Costeira

e dos Índices de Evolução da Vulnerabilidade

Tabela 3 - Identificação dos objetivos, linhas estratégicas

e ações do POC ACE para a Cova do Vapor

Tabela 4 - Perfil do utilizador da praia da cova do vapor 


\section{Introdução}

\section{Âmbito do estudo}

O presente estudo resulta de uma encomenda da associação EDA - Ensaios e Diálogos Associação à CEU - Cooperativa de Ensino Universitário (entidade instituidora da Universidade Autónoma de Lisboa), no âmbito do projeto TransforMar+, apoiado pelo Mar 2020-GAL ADREPES COSTEIRO, tendo o estudo sido realizado pelo Centro de Estudos de Arquitetura, Cidade e Território da Universidade Autónoma de Lisboa (CEACT/UAL).

Este projeto surgiu na sequência de um conjunto de ações promovidas por esta associação, em conjunto com outras entidades e projetos locais (ex. Biblioteca do Vapor, Câmara Municipal de Almada), com vista à sensibilização ambiental e intervenção localizada na área dunar da Cova do Vapor (Almada).

O CEACT/UAL, em parceria com o projeto TransforMar, organizou (em julho de 2018) um workshop de projeto e construção em arquitetura (in situ/8), no qual procedeu ao desenho e construção de algumas estruturas de acesso à praia e de regularização dos caminhos pedonais. Na sequência deste workshop, que realizou uma análise do território, no que diz respeito à relação entre as dunas, a praia e o aglomerado urbano, surgiram questões que são desenvolvidas ao longo das páginas seguintes e que, em conjunto com as restantes fontes, resultaram nos cenários que são propostos no final.

O estudo tem como objetivo geral a identificação de possibilidades de atuação para a boa preservação e promoção dos recursos culturais, naturais e paisagísticos da zona das dunas, junto ao aglomerado urbano na Cova do Vapor, Almada. Tem como objetivos específicos:

- definir uma proposta de programa e localização de equipamentos que visem promover uma melhor utilização deste espaço;

- identificar possíveis correlações virtuosas entre a estrutura urbana existente e a estrutura dunar para a promoção do equilíbrio ambiental, social e territorial daquele espaço.

\section{Metodologia}

Do ponto de vista metodológico, o estudo assentou em três abordagens:

- levantamento de campo;

- análise da documentação e bibliografia existente sobre a Cova do Vapor e dos Instrumentos de Gestão do Território em vigor para a área de estudo;

- realização de entrevistas e uma sessão de dinamização de debate de problemas e discussão dos cenários com atores locais;

- realização de inquéritos aos utentes da praia da Cova do Vapor.

As quatro abordagens foram complementares e tiveram como pressuposto de partida a importância da mediação e conciliação de interesses, num território onde coexistem 


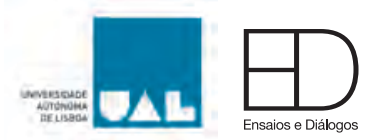

condicionantes diversas, do ponto de vista ambiental e social, marcado, ao longo de décadas, por intervenções potencialmente causadoras de conflitos de base territorial.

As propostas que resultam desta metodologia refletem duas preocupações distintas, que presidiram a todo o estudo: a) o foco da abordagem assenta na inevitabilidade de discutir e implementar estratégias para a proteção ambiental da zona de estudo, independentemente da discussão inerente ao núcleo urbano da Cova do Vapor; b) dada a natureza de todos os agentes locais envolvidos (instituições públicas, agentes privados, associações e cidadãos individuais) as estratégias a apresentar deverão ser apresentadas sob a forma de cenários e ter a capacidade de, futuramente, ser concertadas com todos os agentes locais, e a sua concretização aberta à flexibilidade necessária aos meios disponíveis. 


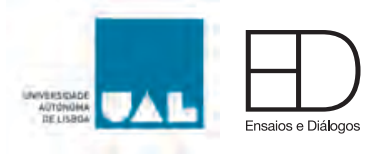

\section{Caraterização da área de estudo}

\subsection{Enquadramento sociogeográfico}

A Cova do Vapor situa-se na Península de Setúbal, no concelho de Almada, no território pertencente à Junta da União das Freguesias de Caparica e Trafaria, localizando-se na margem esquerda da foz do rio Tejo, na confluência deste com o Oceano Atlântico (Mapa 1). A área de estudo abrange a praia, a duna e o aglomerado urbano da Cova do Vapor (Mapa 2).

Do ponto de vista da ocupação urbana, trata-se de uma pequena localidade, de génese informal, com uma população residente, segundo os dados recolhidos nos Censos 2011 (Instituto Nacional de Estatística, 2011) de 183 pessoas, pertencendo a 78 famílias (maioritariamente famílias com um ou dois elementos), com a seguinte distribuição etária: 0-19 - 35 indivíduos; 20/64 - 106 indivíduos; +65 - 42 indivíduos. Segundo este recenseamento, o lugar da Cova do Vapor possui 267 edifícios clássicos, 130 dos quais são edifícios isolados, 265 exclusivamente residenciais, $257 \mathrm{com}$ um ou dois pisos. A estes edifícios correspondem 328 alojamentos clássicos, 78 dos quais são residência habitual, todos eles com água, banho, retrete e esgotos.

No que diz respeito à escolaridade dos residentes registam-se os seguintes dados: 7 indivíduos não sabem ler e escrever, 26 frequentam a escola, 74 completaram o primeiro ciclo do ensino básico, 36 o segundo, 32 o terceiro, 13 o secundário, 1 o póssecundário e 4 o ensino superior.

Em relação à situação face ao trabalho, 19 indivíduos encontravam-se desempregados, 46 empregados (33 dos quais no setor terciário), 53 eram pensionistas ou reformados e 92 não exerciam qualquer atividade económica. O facto de a soma de situações ser superior à do número de residentes poderá talvez justificar-se pela sobreposição de situações.

Estes dados, embora certamente algo desatualizados, permitem-nos concluir alguns aspetos importantes para conhecer melhor a Cova do Vapor. Em primeiro lugar, tratase de um aglomerado de baixa densidade, com edifícios quase exclusivamente residenciais, onde apenas $23,8 \%$ dos alojamentos são de residência permanente, nos quais reside uma pequena população, com $23 \%$ de indivíduos com 65 ou mais anos e $19,1 \%$ de jovens com menos de 20 anos. A escolaridade da população é relativamente diversificada, e a ocupação profissional daqueles que trabalham centra-se essencialmente no setor secundário, o que é caraterístico das áreas urbanas. Destacase o elevado número de residentes sem atividade económica.

Este aglomerado localiza-se numa área, do ponto de vista geográfico, relativamente recente, dado que as alterações da linha de costa, a construção de infraestruturas e a pressão urbana provocaram alterações territoriais significativas, desde a década de 30 do século $X X$, como veremos no ponto seguinte. 
MAPA 1 - ENQUADRAMENTO DA ÁREA DE ESTUDO

ESC. 1/200 000

Cabo da Roca

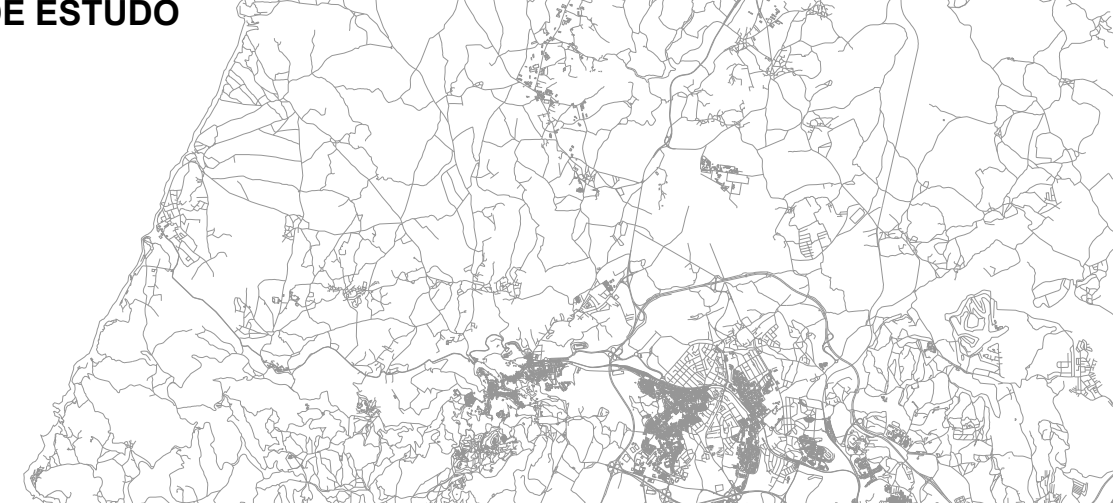

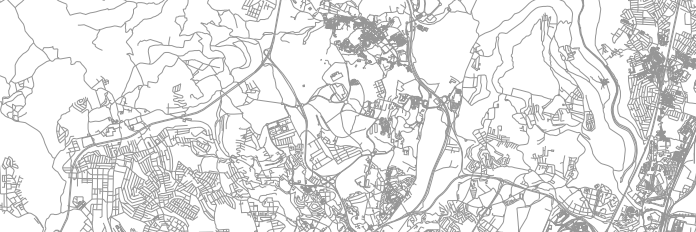

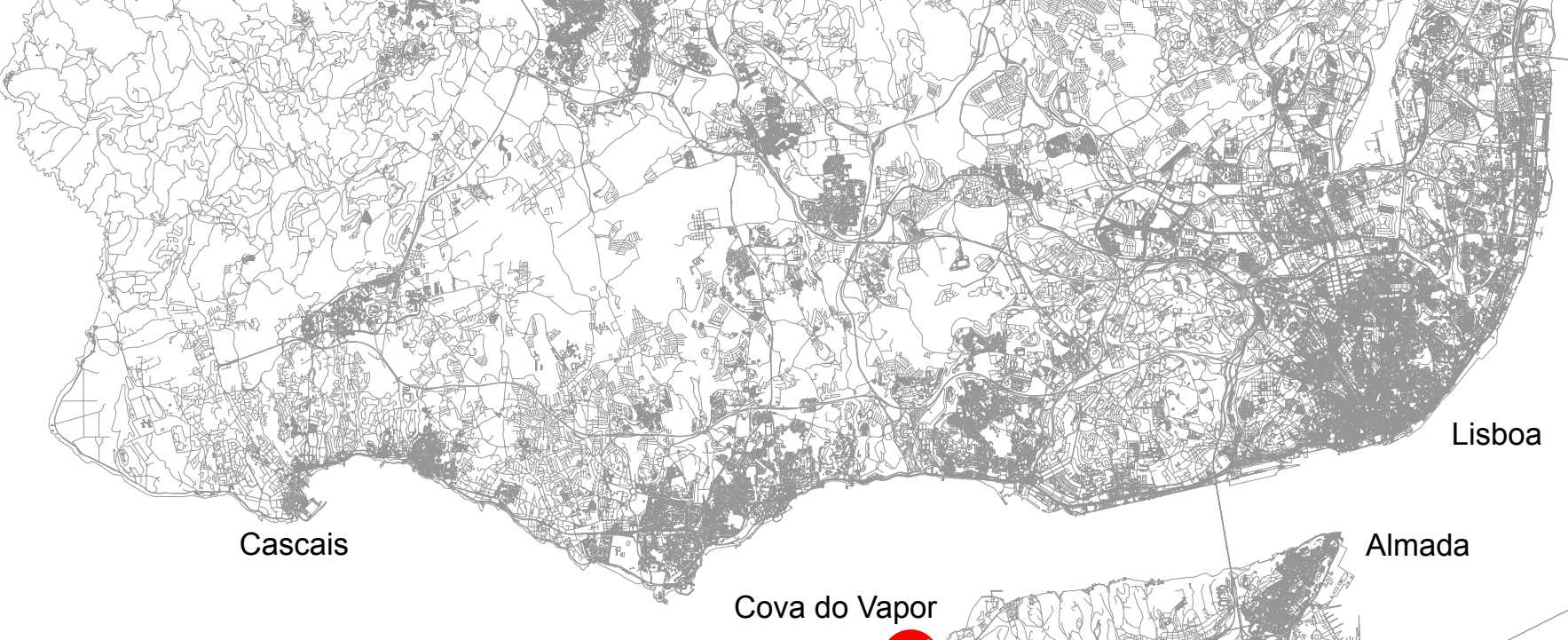

Rio Tejo

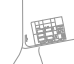

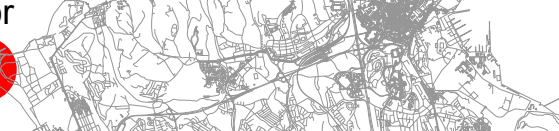

3.

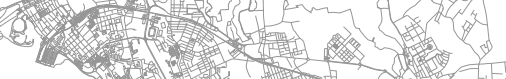

Oceano Atlântico 
MAPA 2 - ÁREA DE ESTUDO

ESC. $1 / 5000$

1. Avenida António Martins Correia

2. Rua Jorge Loureiro

3. Avenida João Dias Mourinha

Rio Tejo

4. Rua Fernando Gouveia

5. Rua Manuel Furtado Leite

6. Rua do Parque

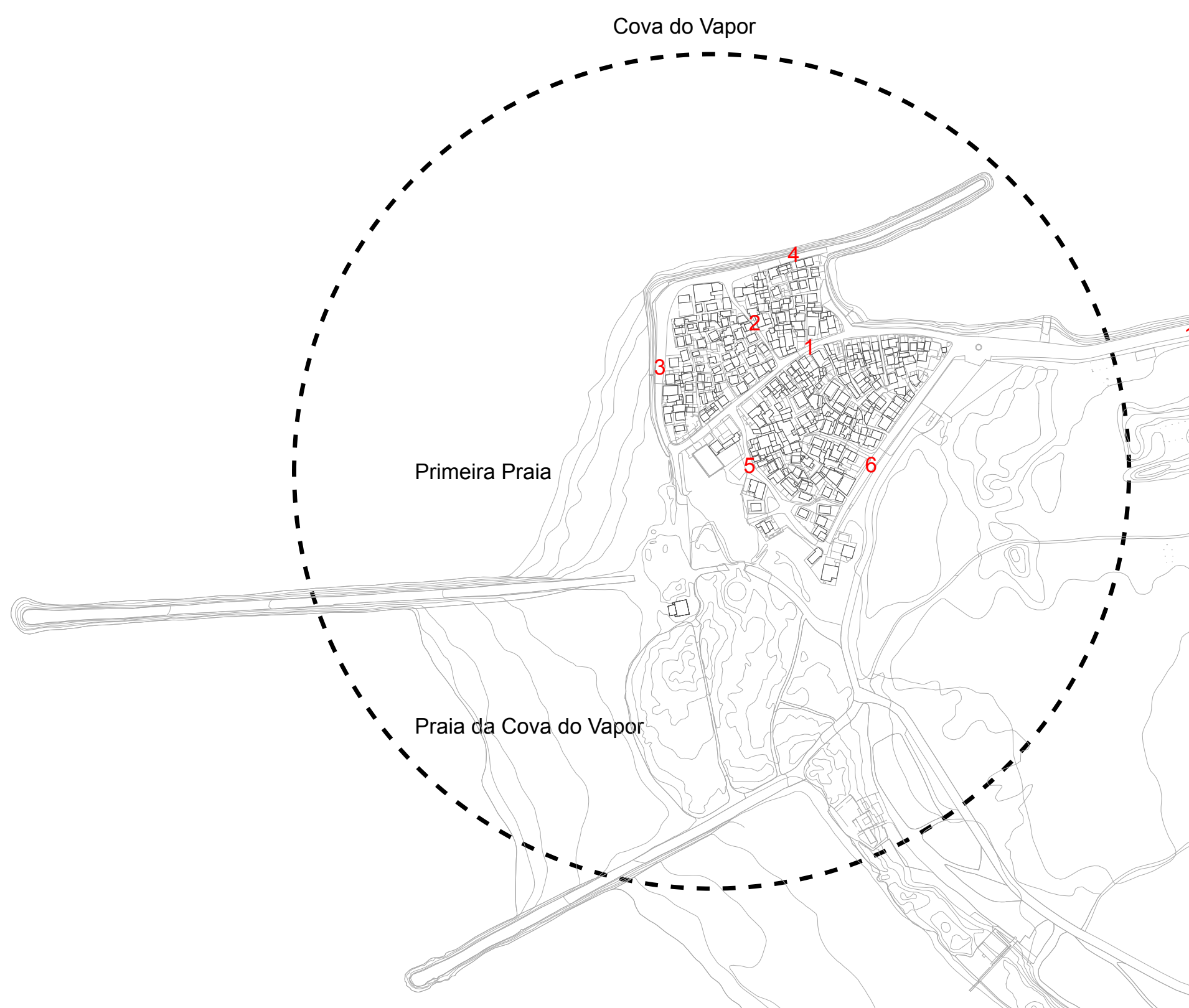

São João da Caparica 


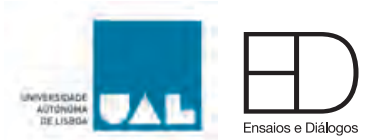

Importa aqui fazer uma breve introdução física e ambiental deste território, de modo a enquadrar os pontos seguintes. A análise apresentada em seguida tem como principal fonte os estudos de caraterização para a revisão do Plano Diretor Municipal (PDMA), realizados entre 2011 e 2016, e o Estudo de Enquadramento Estratégico (EEE) para a área que se designou Costa da Trafaria, realizado por uma vasta equipa de técnicos e especialistas, em 2004, no âmbito de um protocolo entre a Câmara Municipal de Almada e a Urbanizadora Praia do Sol, proprietária de parte significativa dos terrenos da área de estudo. Este estudo tinha em vista a "recuperação urbana e ambiental da zona poente da freguesia da Trafaria" (p. 1|2). Sendo a área de estudo mais abrangente do que a que aqui se debate, apresenta-se uma síntese dos aspetos mais relevantes, sem a pretensão de ser exaustivo na caraterização, mas antes de identificar os aspetos relevantes para os objetivos do estudo e para a discussão subjacente aos mesmos.

\begin{tabular}{|l|l|}
\hline Elementos geográficos & \multicolumn{1}{|c|}{ Aspetos mais relevantes para a Cova do Vapor } \\
\hline Clima & $\begin{array}{l}\text { Clima marítimo de transição (verões quentes - temperatura } \\
\text { máxima média entre } 29^{\circ} \text { e } 32^{\circ} \text { - e invernos suaves). }\end{array}$ \\
\hline Geomorfologia e geologia & $\begin{array}{l}\text { Planície litoral, areias constituídas por siltes e areias finas, com } \\
\text { a presença de um cordão dunar, que forma um "cotovelo" que } \\
\text { define o fim do estuário do Tejo e o início das praias oceânicas. }\end{array}$ \\
\hline Sismicidade & Registados valores de sismicidade elevados. \\
\hline Vegetação e flora & Ecossistema de duna primária. \\
\hline Solos & Área social, sem aptidão agrícola. \\
\hline Uso do solo & $\begin{array}{l}\text { Litoral arenoso, com área urbana consolidada degradada } \\
\text { adjacente. }\end{array}$ \\
\hline Permeabilidade & Área de infiltração máxima. \\
\hline Tipo de paisagem & $\begin{array}{l}\text { Paisagem fortemente humanizada, resultado de uma pressão } \\
\text { humana considerável sobre os recursos naturais. }\end{array}$ \\
\hline
\end{tabular}

Tabela 1 - Síntese das principais caraterísticas geográficas da Cova do Vapor (Fonte: AAVV, 2004).

A leitura da Tabela 1 permite identificar a área em estudo como localizada numa área ambientalmente sensível, pela fragilidade do sistema ecológico que a suporta. No que diz respeito ao clima, é ainda importante referir a existência de fenómenos climáticos extremos, sobretudo as tempestades marítimas, que ocorrem durante o inverno. Constata-se ainda uma desadequação entre a geomorfologia de dunas e solos constituídos basicamente por areias, e a ocupação do território com construções de alvenaria implantadas sem qualquer tipo de planeamento.

É importante referir que, embora a sua configuração seja historicamente recente, estamos na presença de um território já muito transformado, com uma dinâmica de precariedade permanente, quer devido às suas caraterísticas geográficas e geofísicas, quer sociais. É disso exemplo o recuo significativo, desde os anos 40 do século $X X$, da linha de costa na área entre a Cova do Vapor e a Costa da Caparica. 


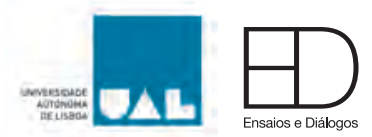

Desde 1964 que se iniciaram obras de proteção da povoação através da criação de barreiras em pedra, no sentido de quebrar a força das ondas e impedir a destruição das habitações. Durante as décadas seguintes, resultado de ações planeadas ou em resposta a acidentes particularmente violentos, como os ocorridos já durante o século XXI, foram sendo realizadas ações de reforço e consolidação das barreiras existentes. $O$ lado norte da Cova do Vapor encontra-se assim totalmente artificializado. A este do núcleo urbano resultando do desassoreamento da face interna do pontão existe um pequeno porto de abrigo, que é utilizado por alguns pescadores para atracagem de embarcações de pesca local.

É necessário referir também que a área em estudo se encontra na proximidade da Praia de São João da Caparica, da área de mata, e de outro núcleo urbano de génese clandestina, o 20 Torrão, e de estruturas pesadas, como é o caso dos esporões e do pontão de abastecimento e viaduto da Pol Nato. A pressão humana que resulta desta localização e destes fatores é de caráter permanente, mas agrava-se significativamente durante a época balnear. Os estudos para a elaboração do PDMA consideram que esta zona como "zona de relevo dunar degradado", integrada no Sistema Litoral, com uma elevada suscetibilidade à erosão, que é agravada pelo pisoteio desregrado, e pela pressão urbanística causada pela construção ilegal, mas também pela pesada infraestruturação. Acrescem a estes aspetos o cenário da subida do nível médio da água do mar e a probabilidade crescente de ocorrências de fenómenos climáticos extremos, como tempestades. Podemos, pois, afirmar que estamos na presença de um território com fortíssimas condicionantes, do ponto de vista geográfico, ambiental e sociocultural. A interação entre as componentes bióticas, abióticas e antrópicas é um fator comum a todo o território nacional, mas, em territórios frágeis como é o caso da Cova do Vapor, assume dimensões para as quais, muitas vezes, os instrumentos existentes não oferecem resposta.

A Cova do Vapor possui duas praias, uma junto ao núcleo urbano, designada por Primeira Praia, e outra junto à praia de São João da Caparica, designada nos Instrumentos de Gestão do Território por Praia da Cova do Vapor, mas também conhecida por Praia do Albatroz, o nome do apoio de praia aí existente. Neste documento adotam-se as designações Primeira Praia e Praia da Cova do Vapor, respetivamente (Mapa 2). 

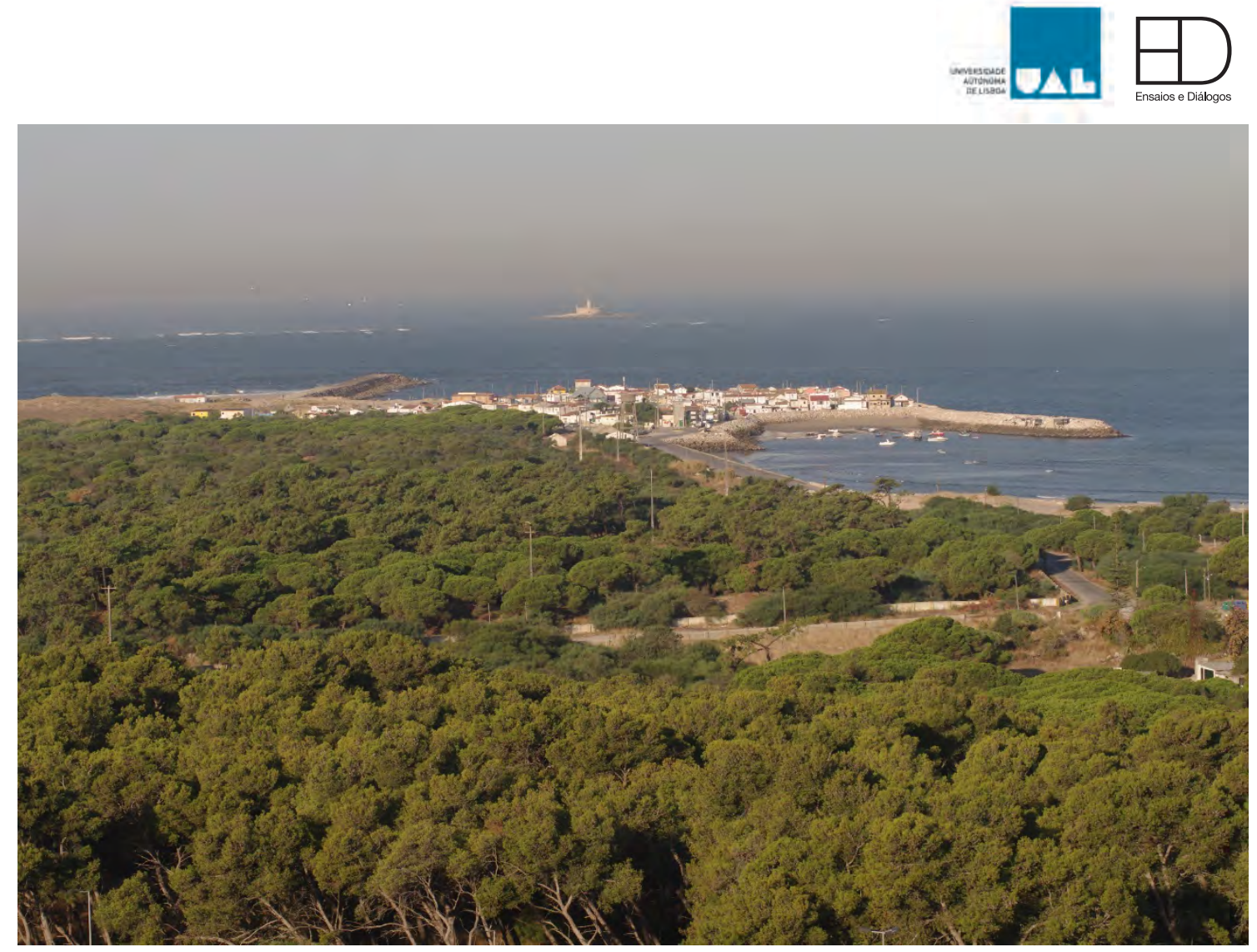

Figura 1 - Panorâmica da Cova do Vapor (foto: Francisco Silva, 2017).

\subsection{Enquadramento histórico}

A Cova do Vapor localiza-se numa área da foz do rio Tejo que sofreu constantes mutações no último século. As dinâmicas fluviais e marítimas transformaram o perfil da costa, constituída exclusivamente por areia e duna. As caraterísticas instáveis do local inibiram, até às primeiras décadas do século $X X$, qualquer tipo de ocupação ou fixação populacional. A origem dos primeiros assentamentos na Cova do Vapor encontra-se diretamente ligada à prática balnear. Não se encontra nenhuma referência a que no local tenha existido alguma aldeia de pescadores, sendo que os assentamentos das comunidades piscatórias locais se encontram a norte e a sul da Cova do Vapor, a Trafaria e a Costa da Caparica respetivamente. 

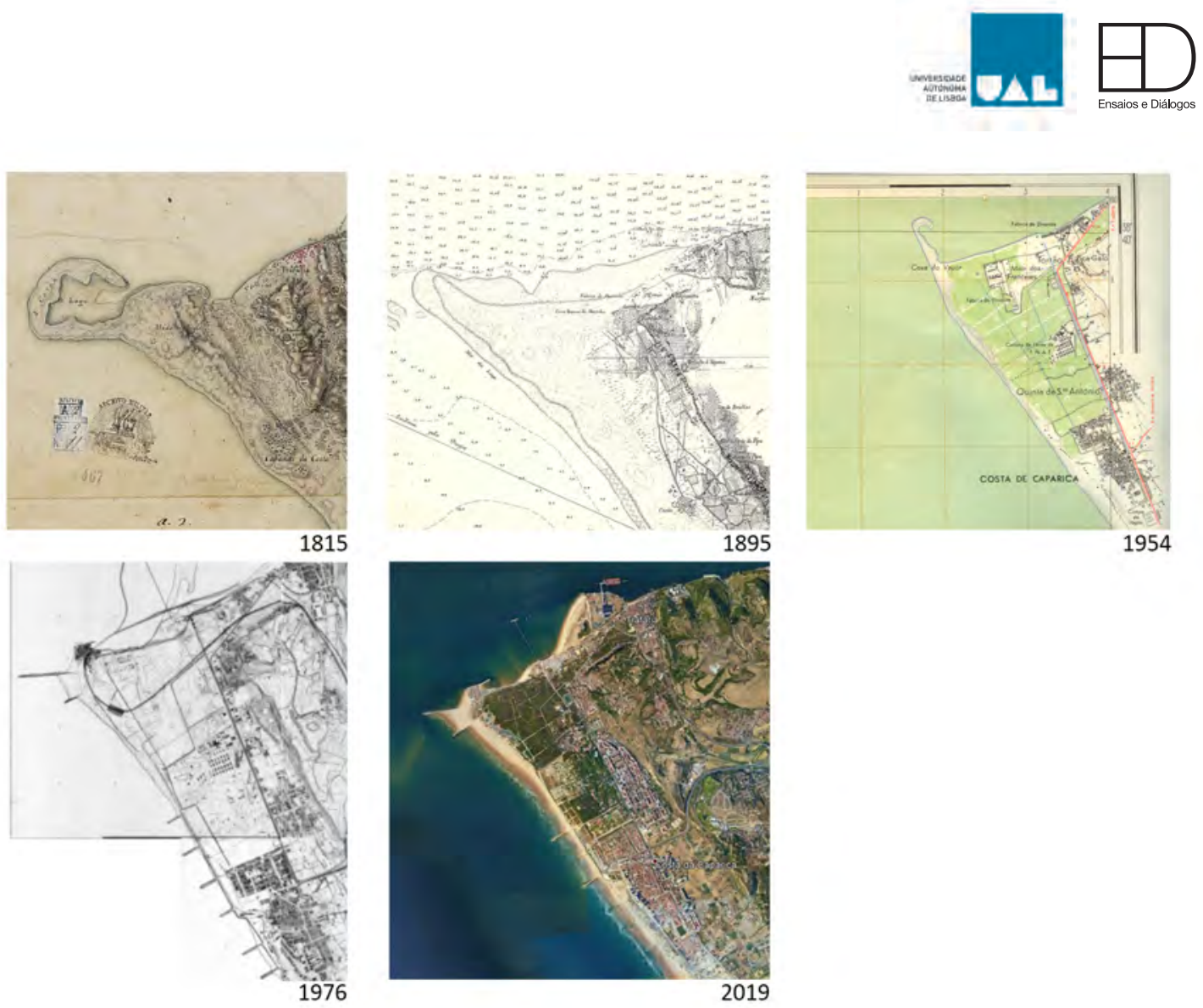

954

Figura 2 - Evolução do território da Cova do Vapor (1815-2019). Fonte: a) Carta Topográfica Militar do Terreno da Península de Setúbal (Excerto), COSTA, José Maria das Neves, 1815. b) Plano Hidrográfico da Barra do Porto de Lisboa, 1893. c) Carta Militar de Portugal, 1954. d) Levantamento aerofotogramétrico, CMA, 1976. e) Google Earth, 2019.

A fixação de populações na margem esquerda da foz do Tejo bem como da frente atlântica do concelho de Almada é relativamente tardia, em virtude da insalubridade, resultante da existência de grandes áreas pantanosas onde proliferavam mosquitos transmissores de paludismo, e ausência de terrenos aráveis ou vias de comunicação.

Na Trafaria os primeiros assentamentos datam do século XVII e, nas praias atlânticas da Costa (da Caparica), do século XVIII. Principalmente na frente atlântica, a influência das populações com origem na Beira Litoral e no Algarve manifesta-se na arquitetura habitacional, constituída, até ao início do século XX, maioritariamente por barracas de madeira com telhados de estorno, dada a ausência de outros materiais, inacessíveis financeiramente às comunidades locais.

A praia da Trafaria começa desde finais do século XIX a atrair durante a época balnear ${ }^{1}$, que decorria entre 1 de Setembro e 21 de outubro, os "banhistas" lisboetas de classe média e da burguesia: "Hoje a Trafaria Conta na quadra balnear uma numerosa e escolhida população d'este género, uma população não só escolhida mas distincta, entre a qual notabilidades literárias, como D. Guiomar Torrezão, Bulhão

\footnotetext{
${ }^{1}$ Postura municipal da Câmara Municipal de Almada datada de 1886 


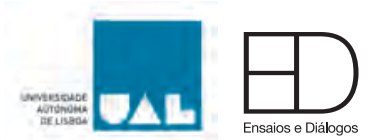

Pato, Ramalho Ortigão, etc., etc. ${ }^{2}$. Em 1909, o Real Instituto de Socorros a Náufragos inaugura na Trafaria o primeiro posto de apoio a banhistas. ${ }^{3} \mathrm{Em} 1911$, durante a época balnear, era assegurada a ligação regular de barco a vapor entre Belém e a Trafaria. Com a classificação da Costa da Caparica como estância balnear, em 1926, a praia da Trafaria vai perdendo importância em favor da Costa, onde se vai concentrar o investimento imobiliário vocacionado para as classes sociais com poder económico para aquisição de "casas de praia".

O lugar onde surgiram os aglomerados de barracas que tomaram a designação de Cova do Vapor e Lisboa Praia situa-se no extremo oeste do concelho de Almada, numa zona onde a dinâmica fluvial e marítima criou condições para a instalação de habitações de apoio aos banhistas, sobre as areias então emersas, encontrando aqui, no domínio público marítimo, um espaço que podiam ocupar mediante o pagamento de uma licença anual.

Respondendo ao fluxo cada vez maior de banhistas às praias da margem sul, oriundos de Lisboa, a praia da Trafaria, onde se chegava facilmente por barco, encontra-se inserida num núcleo urbano consolidado sem possibilidades de crescimento; por outro lado, a Costa da Caparica encontra-se a mais de quatro quilómetros de distância da Trafaria, e a oferta de alojamento balnear é menos acessível. Estão assim criadas as condições para o surgimento de uma zona balnear popular, acessível através da ligação fluvial com partida de Belém e onde é possível encontrar alojamento económico, a chamada "praia dos tesos".

Parece ter havido, durante as primeiras décadas, uma adequação da ocupação sazonal ao avanço e recuo do cordão dunar, através da relocalização das construções existentes. Esta situação inverteu-se com a progressiva consolidação do edificado, a partir da década de 70 , como se verificará no ponto seguinte.

\subsubsection{A Cova do Vapor na Imprensa}

A documentação histórica sobre a Cova do Vapor é escassa e pouco precisa. Com alguma frequência, são referidos em estudos recentes sobre esta área informações que carecem ainda de confirmação com fontes históricas. Na ausência de referências bibliográficas, é através de um conjunto de recortes de imprensa alusivos à Cova do Vapor que se procura aqui enquadrar a origem e evolução da localidade. Não tendo a preocupação de ser exaustiva, esta abordagem permite sobretudo balizar algumas datas, que permitem fixar um esboço de cronologia.

A primeira notícia sobre a Cova do Vapor encontra-se no Século llustrado de 14 de agosto de 1946, tendo como título "Cova do Vapor praia popular da margem sul deve á Parceria dos Vapores Lisbonenses o seu cómodo e fácil acesso", o texto permite

\footnotetext{
${ }^{2}$ Duarte Joaquim Vieira Junior, Villa e Termo de Almada, apontamentos antigos e modernos para a história do Concelho, Vol. I, Lisboa, Imprensa Lucas, 1897, p. 202.

${ }^{3}$ Carlos Barradas Leal, Outrafaria, CAA, JUFCT, Trafaria, 2014, p. 132.
} 


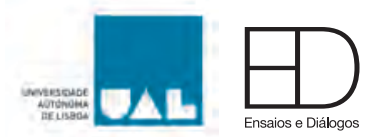

identificar o período em que a praia começa a ser frequentada "Quem adivinhava há trinta anos a praia da Cova do Vapor? O areal, desde as últimas casas da Trafaria até o Bico da Coroa, era uma planície extensíssima que as águas da enchente cobriam e a vazante punha a seco. Não tinha portanto, condições para se tornar uma zona balnear".

O surgimento da praia acessível deve-se, segundo a mesma notícia, à extração de areias para aterros com vista à construção do Porto de Lisboa; estas dragagens alteraram a morfologia dos fundos e criaram uma área de areia permanentemente emersa propícia ao uso balnear: "No ponto onde fizeram a dragagem ficou uma cova onde as águas eram profundas e portanto possuidoras de todas as condições que recomendam uma praia de banhos: fundo de areia sem pedra, transparência cristalina, corrente não impetuosa tranquilidade das marés."

As condições descritas permitiram a instalação de dois núcleos de barracas de madeira, ocupadas sazonalmente por banhistas: Lisboa-Praia e Cova do Vapor; esta última deverá a sua designação à Cova feita pela draga a Vapor. Foi esta mesma draga que, transportando areia extraída da Cova do Vapor, colidiu com o cacilheiro Tonecas que fazia a carreira Cais das Colunas - Cacilhas, no dia 19 de novembro de 1938, provocando o seu afundamento.

A segunda notícia, datada de 14 de novembro de 1950, publicada no Diário da Manhã, com o título "A Cova do Vapor está ameaçada pelas águas que invadem os areais $e$ destroem as casas" descreve o crescimento dos dois aglomerados populacionais então existentes: "Hoje a Cova do Vapor, virada ao Tejo, e Lisboa Praia, com face para o Oceano, constitui já um aglomerado da população que alcança, sobretudo no Verão, certa importância, devido às condições favoráveis do aluguer do terreno pago a $2 \$ 00$, por ano o metro quadrado - sem mais formalidades do que uma licença relativamente fácil de obter na Capitania ou na Administração Geral do Porto de Lisboa, conforme a casa. (...) mas entre as quatro centenas de casas que se erguem no vasto areal, destacam-se já algumas casitas mais cuidadas, dalgum novo veraneante mais endinheirado".

Descreve ainda o efeito das alterações na dinâmica fluvial, resultante da extração de areia: "Recentemente, as necessidades de areia para obras de grande vulto, em que a Administração do Porto de Lisboa está empenhada, obrigaram a novas extraç̧ões de areia no local, considerado o mais propício para o efeito. Os trabalhos, que se verificaram principalmente do lado do Tejo, provocaram um desgaste demasiado que prejudicou a estabilidade dos areais, de tal modo que as águas encontrando menor resistência, começaram a sua perigosa invasão."

Nos anos seguintes, as notícias de imprensa denotam o agravamento da situação de avanço do mar ameaçando as construções erigidas sobre a areia, conforme se depreende dos títulos jornalísticos: É conveniente acudir depressa à Cova do Vapor 


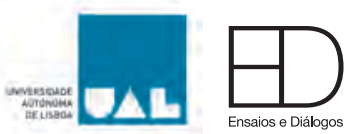

(Diário da Manhã, 16/11/1950); Vai desaparecer a Cova do Vapor onde muitos lisboetas se refugiam durante os meses de Verão? (Diário Popular, 17/01/1951); O mar avança sobre a terra (Século Ilustrado, 13/12/1958). O Diário Popular, de 14 de dezembro de 1958, notícia a total destruição de Lisboa-Praia.

Em janeiro de 1962, o mar volta a destruir habitações na Cova do Vapor, e as notícias referem ainda a continuação da construção de um quebra-mar, iniciada em 1958; paralelamente, algumas das casas em madeira da Cova do Vapor são transportadas para o interior afastando-se a frente ribeirinha. Na sequência da destruição causada pelo mar nas habitações da Cova do Vapor, a Junta Central da Casa dos Pescadores, dirigida pelo almirante Henrique Tenreiro, vai suportar os custos da construção de seis barracas de madeira para alojar moradores cujas habitações ficaram destruídas, embora apenas um dos beneficiários fosse efetivamente pescador. Associada a esta iniciativa de reconstrução ficou a participação de um grupo de estudantes universitários conforme notícia o jornal O Século de 8 de fevereiro de 1962: "Algumas dezenas de estudantes universitários das Faculdades de Direito e do Instituto Superior de Agronomia compareceram ontem na Cova do Vapor, e num simpático gesto de solidariedade trabalharam durante o dia na beneficiação de outras barracas que tiveram importantes danos."

Em março de 1964, o mar volta a ameaçar a Cova do Vapor, sendo noticiado o avanço das obras de proteção da praia, apesar da "dificuldade de acesso de camionagem com material à Cova do Vapor, por ter sido inutilizada a pequena estrada que levava ao esporão meio destruído".

Em 15 de novembro de 1968, o Diário de Notícias notícia "As obras da Costa de Caparica estão já devidamente planeadas", neste artigo resume-se o projeto de proteção da costa nos seguintes termos: "Uma barreira continua (uma muralha com cerca de quatro quilómetros e meio), capaz de suportar a acção direta da ondulação. Este dique no seu projecto definitivo estender-se-á desde o limite Sul da zona urbanística da Costa de Caparica até à parte Norte da Cova do Vapor, já na margem do estuário."

A Cova do Vapor surge de novo na imprensa em 1972, no Diário Popular de 13 de outubro, a propósito de um empreendimento imobiliário que estava projetado para o local. Nessa reportagem é referida a existência de uma "espécie de aldeamento clandestino, emparceira com um parque de campismo» do mesmo estilo, constituindo presentemente, a única "zona residencial» instalada no extremo do terreno da urbanizadora da Praia do Sol..."

Já no século XXI, a Cova do Vapor é tema de um artigo publicado no jornal Público (28/04/2002). O Artigo com o título "Uma Relíquia Chamada Cova do Vapor" invoca memórias de alguns residentes sobre a história da povoação, salientando os seus aspetos pitorescos e comparando-a ao "Portugal dos Pequeninos". Por outro valoriza- 


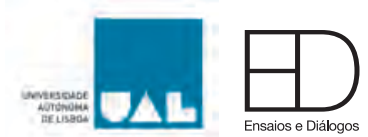

se a participação popular: "Na Cova do Vapor, o poder popular, visto como uma emanação activa e participada da comunidade local, perdura de uma forma pujante e surpreendente." O mesmo jornal volta a publicar, em 24 de julho de 2011, uma reportagem intitulada $A$ Cova do Vapor não é um bairro da lata, é "um tesouro fantástico", aqui destaca-se o projeto desenvolvido pelos arquitetos Filipe Balestra e Sara Goransson, através do projeto TISA - The Informal School of Architecture, no âmbito do qual um grupo de estudantes voluntários construiu uma maqueta da Cova do Vapor.

Em outubro de 2013 (Público 15/10/2013) o arquiteto Manuel Graça Dias retoma o tema de um artigo publicado em 1987 na revista Arquitectura Portuguesa, "Cova do Vapor, qualquer coisa que suponho certa", no qual reflete sobre o interesse das criações arquitetónicas de cariz popular, que, sem serem tradicionais, refletem uma forma de estar e construir, e dos espaços informais resultantes da ausência de planeamento e das vontades individuais e coletivas. Em 2013, o arquiteto regressa, vinte anos mais tarde, com um olhar que reflete sobre mudança e permanência numa aldeia hoje "talvez um pouco menos espontânea, mais endurecida pelo tempo, com menos juventude nas dobras de janelas, no desbotado colorido normativo das paredes mais velhas, com menos memória das leves barracas de praia; com mais carros, com mais 'ordenamento' de empréstimo (lombas dissuasoras, sinais de trânsito, estacionamento marcado). Ainda assim, o excesso de fios de electricidade que, pendurados dos postes de betão, correm o céu das ruas mais largas, dão ao todo um quase perfil denso de arredores de Quioto ou Bombaim, e muitas casas ainda acumulam a história do povoado em acrescentos complexos".

\subsubsection{A ocupação urbana da Cova do Vapor}

Aquando da origem, os assentamentos Lisboa-Praia e Cova do Vapor ocupariam uma área abrangida pelo Domínio Público Marítimo, sendo que os terrenos contíguos pertenciam à Fábrica de Explosivos da Trafaria, a qual terminou a sua atividade em 1966. Com o avanço do mar e o recuo da linha de costa, a administração da fábrica cedeu terreno para recolocar as barracas. A construção de barracas de madeira desmontáveis era autorizada pela Administração Geral do Porto de Lisboa, mediante o pagamento de uma licença renovada anualmente. A partir de 1972, a concessão das referidas licenças é transferida para a Direção-Geral dos Serviços Hidráulicos.

Para enquadrar o tipo de licenças concedidas, destacamos a 3a condição da licença n.o 161/1967, emitida pela Direção-Geral dos Serviços Hidráulicos: "3q - Esta licença é concedida a título precário e com a condição expressa de que se para benefício ou melhoramento público ou da navegação e flutuação for necessário desfazer, inutilizar ou modificar as obras a que se refere esta licença, o seu titular não terá direito a 


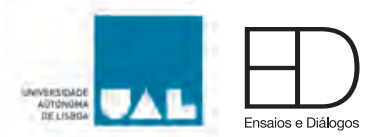

indeminização alguma, nos termos do artigo $263^{\circ}$ do Regulamento para os Serviços Hidráulicos, aprovado por Decreto de 19 de Dezembro de 1892;"

A reportagem do Diário Popular de 13/10/1972 refere que o acesso à Cova do Vapor só é possível através da estrada particular, sujeita a portagem para os não moradores, propriedade da Urbanizadora Praia do Sol. A Cova do Vapor era então composta por 114 casas e duzentos moradores permanentes, não dispunha de eletricidade ou saneamento e o abastecimento de água era garantido por um único chafariz, cuja canalização foi construída por subscrição pública dos moradores.

Apesar de não ser clara a posse efetiva do terreno onde estão construídas as habitações da Cova do Vapor, existem contratos de compra e venda de casas, o que enquadra uma situação que carece de clarificação futura. Na documentação a que se teve acesso, a resposta ao pedido de licença de ocupação mais recente data de 27 de outubro de 1975, quando é constituído por um inquérito sobre as condições de habitabilidade, salubridade, e higiene das construções existentes na faixa do Domínio Público Marítimo.

Tal como se verificou no ponto anterior, este lugar continua, essencialmente, a manter caraterísticas de ocupação sazonal, embora, nas últimas décadas alguns dos residentes tenham transformado habitações secundárias em permanentes, nomeadamente após a sua reforma. Em 2004, uma larga maioria (71\%) dos inquiridos no âmbito do Estudo de Enquadramento Estratégico (p. 3|58) tinha intenção de tornar a sua residência secundária em permanente. Um outro aspeto interessante é o facto de a proveniência dos indivíduos proprietários se estar a diversificar. Embora não existam dados oficiais, os contactos informais realizados durante a preparação e construção do laboratório in situ/ e durante o trabalho de campo realizado para este estudo, revelaram uma presença na Cova do Vapor de diversos residentes oriundos de outros países da Europa (nomeadamente Espanha e França). São residentes normalmente com mais escolaridade, que procuram a Cova do Vapor para habitar e não apenas como espaço de veraneio.

\subsubsection{A vocação balnear da Cova do Vapor}

No litoral português, a atividade balnear teve início nas primeiras décadas do século XX. Esta atividade está relacionada com a presença de segunda habitação, mas também de atividades sociais e económicas (por vezes em regime de economia paralela), como o aluguer e empréstimo de casas durante o verão. A génese balnear, referida anteriormente, da Cova do Vapor tem-se mantido como atividade principal ao longo das últimas décadas. O comércio existente é também bastante vocacionado para o uso balnear (café, padaria, restaurante, loja de roupa, mercearia), e tem como alvo não apenas aqueles que permanecem na Cova do Vapor, mas também os que utilizam a praia vindos de fora, à semelhança do que se passa em todas as outras praias de Almada, que imprimem às ruas um movimento considerável nos dias de verão. 


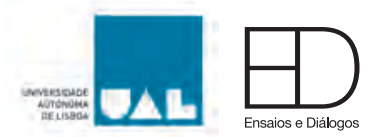

A pesca é uma atividade presente, quer na frente norte quer na praia (em especial nos pontões), mas não a nível profissional e comercial, tratando-se sobretudo de uma atividade de lazer.

Esta situação de forte sazonalidade provoca, tal como acontece junto às praias do país nos meses de verão, situações de congestionamento e mesmo sobrecarga, agravadas neste caso pela quase inexistência de transportes coletivos, pela morfologia urbana e pela ausência de estacionamento ordenado. Estes fatores, como veremos em seguida, constituem uma pressão antrópica, assente na ocupação histórica deste local, que se tem vindo a agravar, face à progressiva degradação da situação natural.

\subsection{Enquadramento geomorfológico e dinâmica sedimentar}

\subsubsection{Enquadramento geomorfológico}

O troço costeiro da Cova do Vapor, localizada no arco litoral da Península de Setúbal, é limitado a norte pelo estuário do Tejo e a sul pelo Cabo Espichel. A Península comporta duas unidades morfológicas principais: o sinclinal de Albufeira e a cadeia da Arrábida.

A cadeia da Arrábida, desenvolvida essencialmente em materiais calcários e detríticos jurássicos e cretácicos, situa-se na extremidade meridional da Península de Setúbal, possui uma orientação de WSW-ENE e corresponde a uma estrutura orogénica que resulta de um episódio de inversão tectónia da Bacia Lusitaniana (Kulberg et al, 2000).

O sinclinal de Albufeira é assimétrico, com inclinações no flanco norte que podem variar entre $5^{\circ}$ a $10^{\circ}$. O eixo coincide com o alinhamento da Lagoa de Albufeira e o seu flanco norte é cortado pela falha do Gargalo do Tejo.

A morfologia do concelho de Almada é caraterizada por quatro tipos fundamentais de relevo: Plataforma Litoral, Vales e Vertentes associadas, Planície Litoral e Arriba Fóssil (Freire, 1989).

No troço costeiro do concelho de Almada, estão presentes três tipos de relevo: plataforma litoral, arriba fóssil e planície litoral. 


\section{Plataforma Litoral}

A plataforma litoral possui uma orientação N/S sendo limitada a oeste pela Arriba Fóssil da Costa da Caparica. Corresponde a uma antiga superfície aluvionar do sistema fluvial de um pré Tejo, com cotas que se apresentam mais elevadas a norte, na ordem dos 90 a 100 m e cotas mais baixas a sul, na ordem dos 50 a 80m (Freire, 1989), sendo a aldeia dos Capuchos um dos pontos mais altos.

\section{Arriba Fóssil}

A Arriba Fóssil da Costa da Caparica materializa o limite leste da planície litoral e oeste da plataforma litoral, sendo a interseção das duas aplanações assinalada por uma vertente muito inclinada. Desde a Trafaria até à Fonte da Telha esta vertente, originalmente talhada por ação marinha, encontra-se separada do mar pela planície litoral e por isso constitui uma arriba fóssil; a sul desta praia passa a sofrer a ação do mar e, por isso, é classificada como arriba viva.

\section{Planície Litoral}

A planície litoral, na qual se localiza a Cova do Vapor, representa uma faixa com orientação aproximadamente N/S, encaixada entre a escarpa da arriba fóssil (a leste) e o oceano Atlântico (a oeste) e carateriza-se por uma extensão lateral que diminui continuamente para sul. A planície litoral possui três elementos morfológicos principais: uma praia, um cordão dunar exterior longitudinal e um campo de dunas interiores que se estendem desde a Trafaria até à Fonte da Telha e são formados essencialmente por areias.

O estudo que Freire (1989) realizou na sua tese sobre a evolução histórica da planície litoral permitiu inferir que desde meados dos séculos XVI e XVIII já existiam representações e referências à presença de bancos arenosos, de canais e de restingas na foz do rio Tejo. A análise histórica de cartas, mapas e até de registos orais permitiu constatar a existência de uma alternância entre o estado de (i)emersão dos bancos de areia, da formação, migração e posterior soldadura de restingas e a presença de canais estreitos e pouco profundos que por vezes isolavam os bancos de areia da planície litoral.

A desembocadura do Tejo é atualmente caraterizada pela presença dos bancos arenosos designados por: Cachopo do Norte (Cachopo do Bico do Pato), Cachopo do Sul (Alpeidão) e Banco da Torre do Bugio. Existe também de um canal principal de vazante - a Barra Grande, e dois canais de enchente - a Barra Norte e a Golada (Figura 3). 

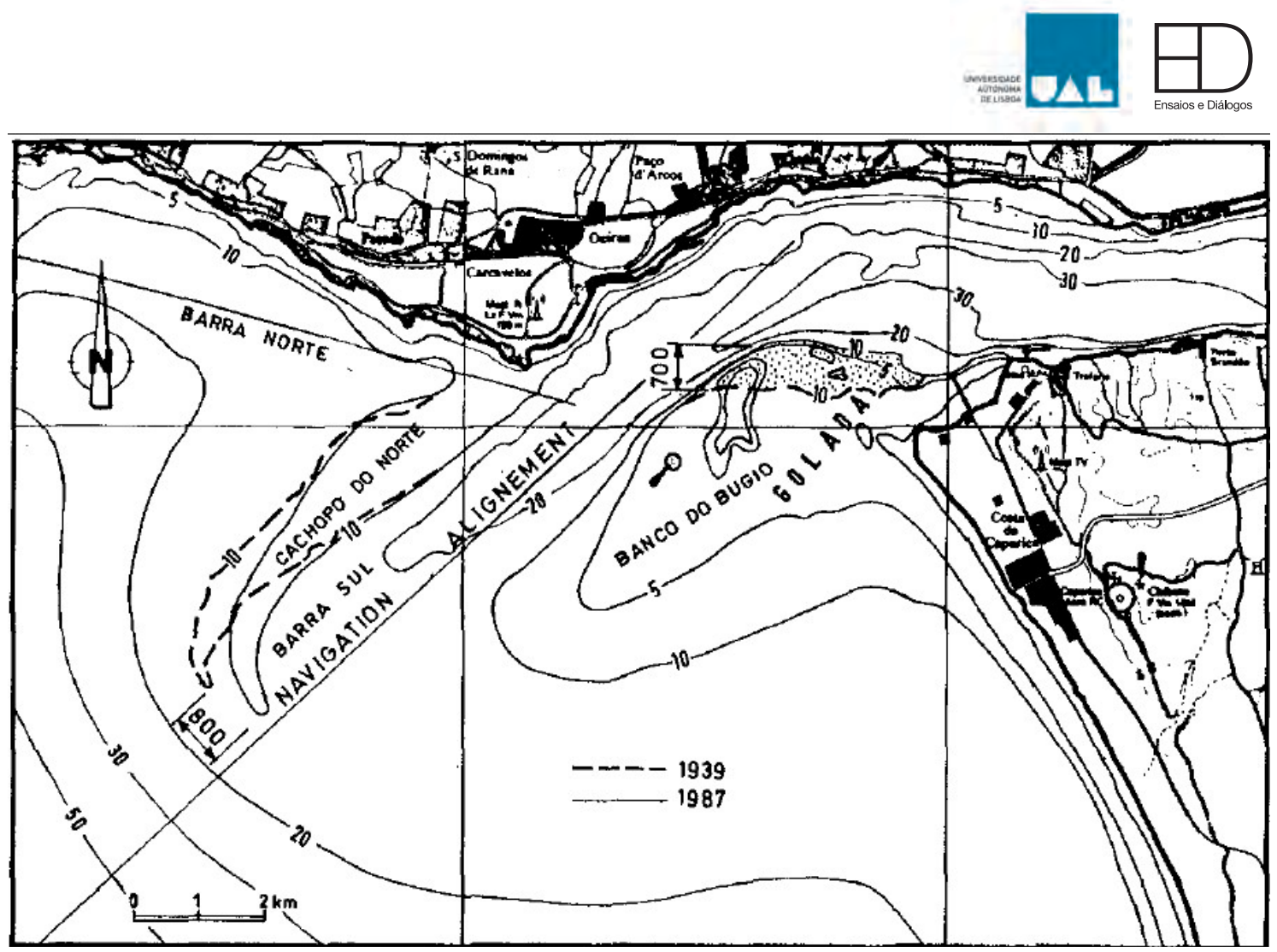

Figura 3 - Localização dos bancos arenosos no estuário do Tejo (Fonte: Oliveira, 1992).

\subsubsection{A evolução da linha de costa no extremo NW do concelho de Almada}

O recuo da linha de costa regista-se em quase toda a costa portuguesa desde meados do séc. XIX, mas ganhou maior expressão ao longo do séc. XX.

As causas principais associadas a este evento prendem-se maioritariamente com ações tomadas no passado e que estão a fazer-se sentir com maior impacto, entre elas o aumento do número de barragens, que aprisionam o sedimento e não o deixam chegar até às zonas costeiras, e as extrações de areia.

O desequilíbrio sedimentar provoca um desequilíbrio na dinâmica das praias, e assistese, assim, a um recuo sucessivo da linha de costa em quase todo o litoral português, contribuindo para a fragilidade do litoral no que diz respeito aos episódios de erosão e galgamento durante os eventos extremos.

O exemplo de um troço costeiro onde se tem verificado um gradual recuo da linha de costa é precisamente o troço da Cova do Vapor, que se situa no arco litoral TrafariaEspichel. Desde a segunda metade do séc. XIX, existem registos das alterações na linha costa do extremo norte do arco Caparica-Espichel, sendo que os primeiros relatos sobre erosões ocorridas na Cova do Vapor remontam ao ano de 1947 (Pinto, Taborda, Andrade, 2007).

A Figura 4 apresenta de forma esquemática a evolução da linha de costa ao longo da segunda metade do séc. XX, observando-se também a migração e soldadura de uma restinga (Freire, 1989). 


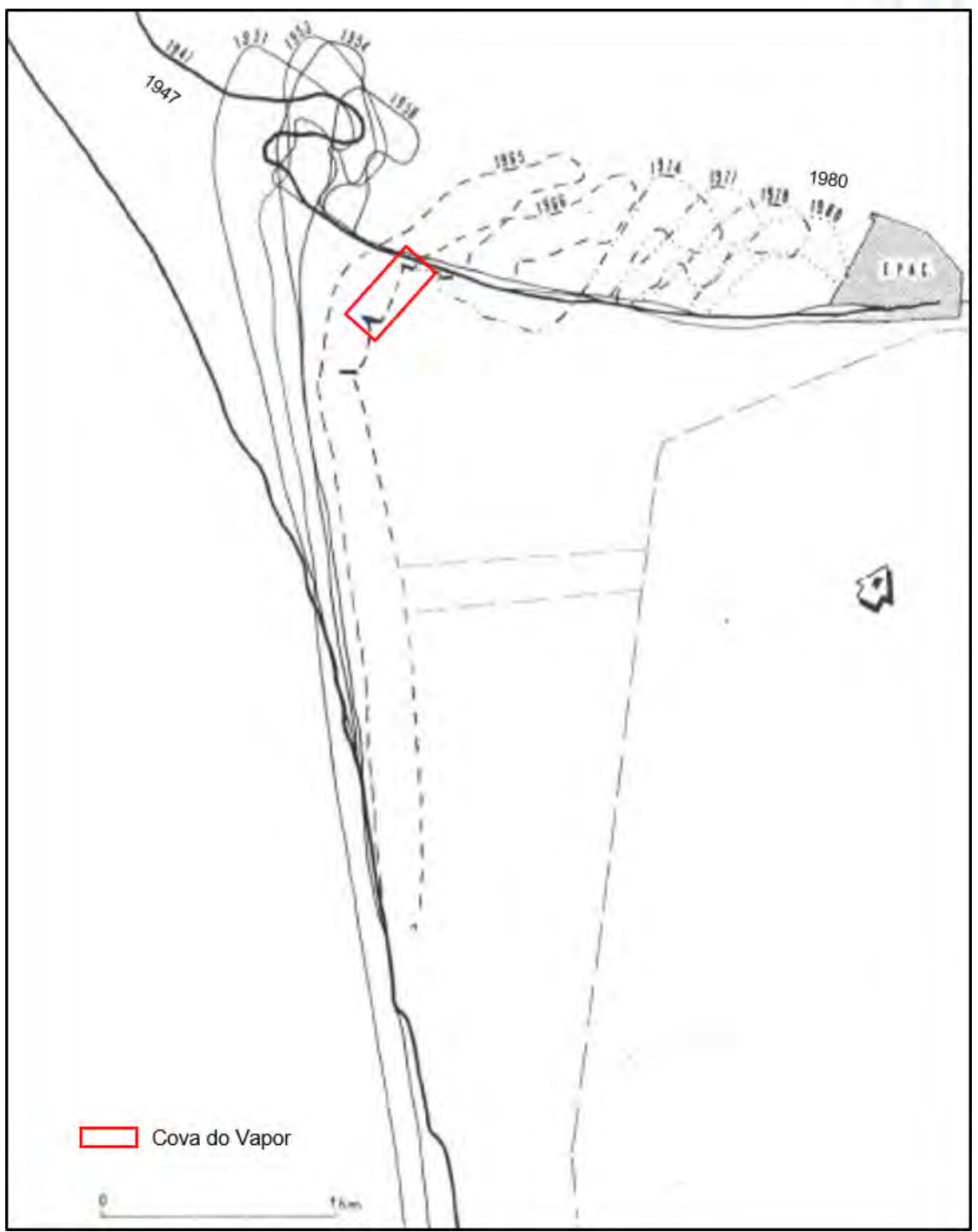

Figura 4 - Evolução da linha de costa entre 1947 e 1980 (Fonte: adaptado de Freire, 1989).

Pinto, Taborda e Andrade (2007) enumeram e resumem as alterações que ocorreram na linha de costa no troço costeiro da Cova do Vapor entre os anos de 1845 e 2007, assim como outros eventos, como a construção dos esporões ao longo do troço costeira da Costa da Caparica, e eventos extremos acompanhados de episódios de erosão:

-1845/1879: recuo de 750m da ponta livre da restinga da Cova do Vapor; -1879/1893: recuo de 400m da ponta livre da restinga da Cova do Vapor;

-1929/1939: avanço de 750m da extremidade livre da restinga da Cova do Vapor na direção da Fortaleza do Bugio e recuo de $200 \mathrm{~m}$ na margem fluvial a oeste da Trafaria. Ligação da restinga da Cova do Vapor ao Bugio (travessia a pé possível em baixa mar de águas vivas);

-1947/1953: redução considerável da restinga da Cova do Vapor;

-1957/1963: erosão intensa da praia e dunas na Cova do Vapor e Costa da Caparica (recuo da zona dunar de $100 \mathrm{~m}$ e diminuição das suas cotas de $14 \mathrm{~m}$ ZH [zero hidrográfico] para 8m ZH); 


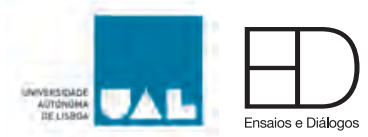

-1971/1995: situação relativamente estabilizada nos segmentos intervencionados, mas com perda progressiva da largura e volumetria da praia;

-Inverno de 1995/1996: erosão da praia e duna frontal com geração de escarpamento e galgamento localizado dos principais acessos à praia;

-Inverno de 1998/1999: erosão da praia e duna frontal com geração de escarpamento e destruição parcial dos apoios de praia na zona de São João da Caparica;

-2000/2001: erosão considerável das praias e duna frontal na Cova do Vapor, São João da Caparica e Costa da Caparica.

-Inverno de 2002/2003: destruição da crista da duna frontal na praia de São João da Caparica, colocando em risco os parques de campismo e outras construções;

-Inverno de 2006/2007: erosão intensa no sector Cova do Vapor/São João da Caparica, recuo da duna frontal e perda de largura da praia emersa. Rotura iminente do cordão dunar e risco de galgamento. Destruição de um apoio de praia localizado na duna frontal.

Para além de observar a variação temporal e espacial da linha de costa no troço costeiro em estudo, Silva et al (2014) e Pinto, Taborda e Andrade (2007) dedicaram-se à quantificação do recuo e não só estimaram o recuo total da linha de costa num determinado intervalo temporal, como também quantificaram a taxa de recuo anual.

A quantificação do recuo da linha de costa realizado por Silva et al (2014), corresponde a um período de 52 anos (entre 1958 e 2010). Os resultados revelaram que o recuo foi em média de $215 \mathrm{~m}$, tendo-se registado, num momento em particular, um recuo máximo de $265 \mathrm{~m}$. As maiores variações na linha de costa decorreram entre 1958 e 1980, tendo menor expressão entre 1980 e 2005; nos últimos 5 anos (até 2010), a tendência do recuo da linha de costa desvanece-se.

A taxa de recuo da linha de costa encontra-se na ordem dos $-4 \mathrm{~m} / a n o$ (valor médio); parte desta contribuição adveio do intervalo temporal entre 1958 e 1980, em que a taxa de recuo rondou os $-8 \mathrm{~m} / \mathrm{ano}$. De 1980 a 2005 os valores de recuo foram mais reduzidos (na ordem dos $1 \mathrm{~m} / \mathrm{ano}$ ), chegando mesmo a verificar-se um momento em que a evolução da linha de costa foi positiva, mas de magnitude muito reduzida (Figura 5). 


\section{$=0 \mathrm{D}$}

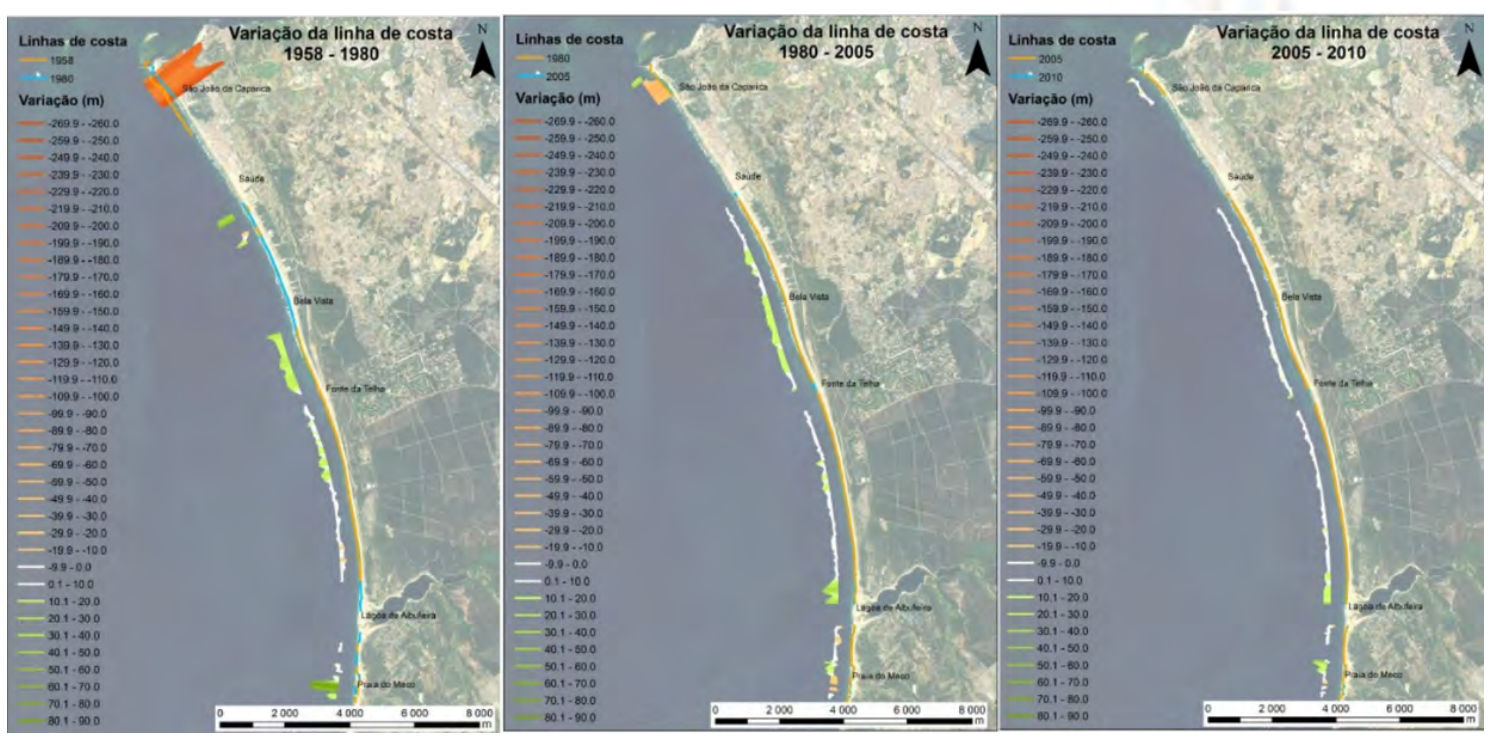

Figura 5 - Evolução da linha de costa no intervalo temporal 1958-2010 (Silva et al, 2014).

A quantificação da variação da linha de costa segundo Pinto, Taborda, Andrade (2007) decorreu entre os anos de 1999 e 2007 no troço Cova do Vapor/São João da Caparica. A estimativa deu um recuo total na ordem dos $26 \mathrm{~m}$ a uma taxa de $3,3 \mathrm{~m} /$ ano. No intervalo $1999 / 2002$ o recuo total foi de $15 \mathrm{~m}$ a uma taxa de $5 \mathrm{~m} / \mathrm{ano}$, enquanto no intervalo $2002 / 2007$ o recuo médio total foi de $12 \mathrm{~m}$ a uma taxa de $2 \mathrm{~m} / \mathrm{ano}$.

Ambos os estudos demonstraram que a linha de costa no extremo NW do arco litoral Trafaria/Espichel está em constante evolução, mais precisamente em constante recuo. Esta evolução configura algumas fragilidades a toda a costa nomeadamente a este troço costeiro em especial; quanto maior o recuo da linha de costa, menor é a largura da praia, mais significativas serão as erosões, galgamentos, inundações e também os impactos no sistema dunar que marginaliza este troço.

Apesar de não se ter o conhecimento exato da magnitude do volume de areia que foi dragado ao longo do século XX dos bancos de areia a norte da Cova do Vapor, sabe-se que, nas décadas de 40 e 50, grandes quantidades de areia foram dragadas. Estas eram maioritariamente destinadas às obras que se encontravam a decorrer no Porto de Lisboa e também ao enchimento das Praias do Sol que já evidenciavam perda de areal devido à erosão marinha (Freire, 1989). No presente, são ainda feitas dragagens nesta área, destinadas sobretudo à manutenção dos canais de navegação do Porto de Lisboa.

\subsubsection{A tendência futura}

As zonas costeiras são regiões muito dinâmicas e sujeitas a uma grande diversidade de agentes naturais e pressões antrópicas tornando por vezes difícil identificar a origem das mudanças nelas observadas (GTL, 2014). Por vezes é também difícil diferenciar entre os impactos resultantes da pressão antrópica, como é o caso da extração de areias, e os impactos associados às alterações climáticas, como a subida do nível do $\operatorname{mar}(G T L, 2014)$. 


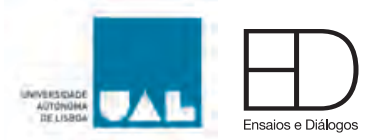

As zonas costeiras apresentam atualmente uma forte pressão antrópica, redução do seu budget sedimentar, alterações na posição da linha de costa e destruição de dunas. As alterações climáticas potencializam todos estes fenómenos e são ainda responsáveis pela ocorrência de novos fenómenos: subida do nível médio do mar e alterações no regime dos temporais e das ondas no litoral. Estes fenómenos são responsáveis por erosões no perfil de praia e nas dunas costeiras, galgamentos e inundações costeiras, alteração na direção do transporte sólido, entre outros.

O troço costeiro da Cova do Vapor encontra-se inserido nos tipos de litoral baixo e arenoso (Figura 6) com uma dinâmica ativa e antiga, relativamente à posição da linha de costa e à ocorrência de episódios de erosão - tanto na praia como na duna -, e com elevada pressão antrópica. A Cova do Vapor, assim como outros troços costeiros, apresenta-se vulnerável relativamente aos problemas de erosão e, por isso, as previsões da evolução futura são que, com o emagrecimento sedimentar das praias e a subida do nível do mar, se continue a verificar um recuo da linha de costa em direção a terra, os fenómenos de erosão continuem a ocorrer, e os sistemas dunares sejam continuamente colocados em risco (Veloso-Gomes, 2002).

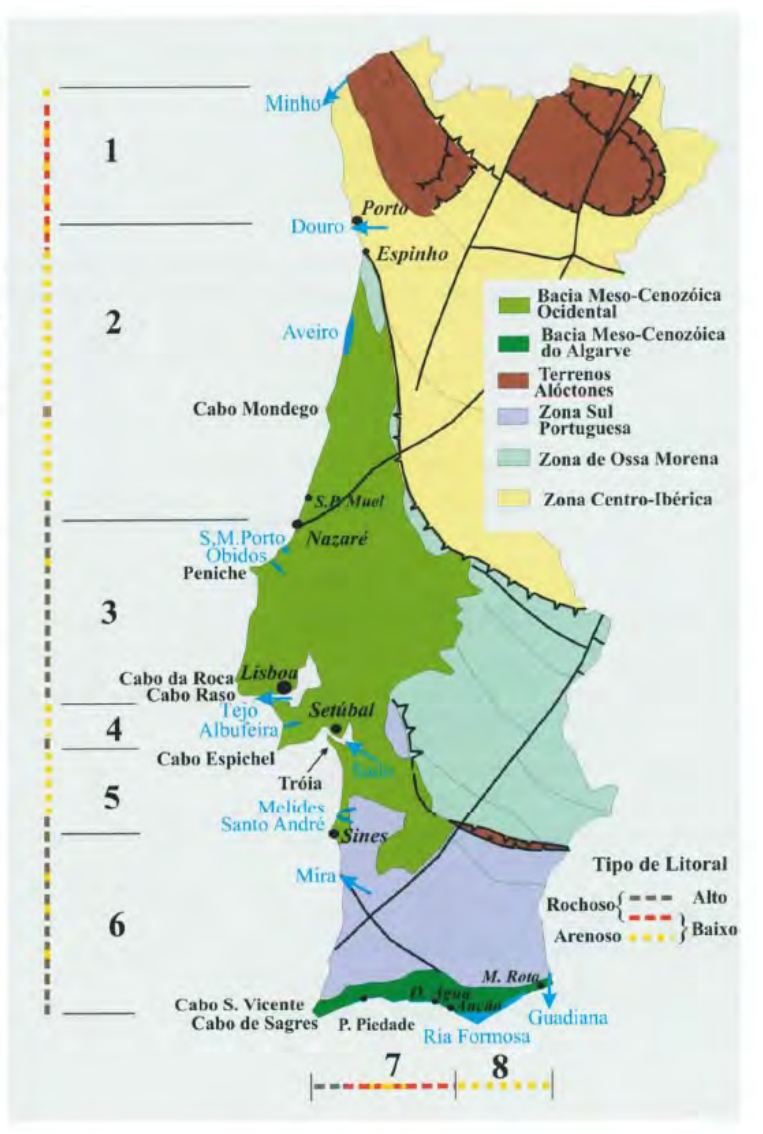

Figura 6 - Divisão da zona costeira em tipos de litoral (Fonte: Santos, 2006).

Atualmente, de forma a tentar mitigar os impactos enumerados anteriormente, tomam-se medidas de ordenamento do território, entre outras, ao nível da proibição da existência de construções em zonas de elevado risco e/ou vulnerabilidade, procurando evitar a degradação presente e futura dos ambientes. Recorre-se também 


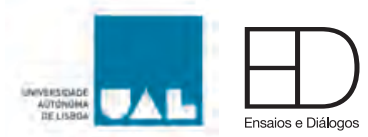

a intervenções leves, como as alimentações artificiais das praias para robustecer o perfil de praia, tentando atenuar o recuo da linha de costa e fornecer ao sistema costeiro condições de dissipação da energia das ondas e tempestades, que se prevê que venha a ser cada vez mais elevada, e que são responsáveis pelas erosões registadas.

\subsection{Enquadramento ecológico e dinâmica dunar}

\subsubsection{Valores naturais}

O território da Cova do Vapor está localizado no extremo NW do concelho de Almada, fazendo a interface entre o estuário e a frente atlântica, pelo que apresenta um elevado valor de conservação, incluindo inúmeros elementos que merecem destaque.

A modelação geográfica dos indicadores de biodiversidade para o concelho de Almada identifica para este território, que faz a transição entre o meio estuarino e costeiro no concelho de Almada, uma importante função como corredor ecológico. Os seus valores naturais e potencial ecológico colocam-no em destaque para a potenciação e manutenção dos elevados níveis de biodiversidade existentes.

Do lado marinho, destaca-se imediatamente o facto de todas as comunidades dunares constituírem habitats classificados da Diretiva Habitats (habitats 1210, 2110, 2120, 2130pt1*, 2230 e 2250pt1*), com especial atenção para o habitat 2110 - Dunas móveis embrionárias, praticamente ausente no restante território do concelho de Almada e presente na Praia da cova do Vapor, que, por ter uma praia alta larga, permite que a limpeza do areal não precise de chegar à base da duna.

São ainda encontrados nestes habitats espécies de importante interesse comunitário como o tomilho-carnudo (Thymus carnosus) e a herniaria (Herniaria marítima), classificadas no anexo B-II da Diretiva Habitats. Acrescem ainda alguns endemismos como a perpétua-das-areias (Helichrysum picardii) ou o Rosmaninho (Lavandula luisieri).

Os sistemas dunares albergam neste território a nidificação de borrelho-de-coleirainterrompida (Charadrius alexandrinus), migrador estival e reprodutor nas nossas costas. O estatuto de conservação de borrelho-de-coleira-interrompida no continente é LC (não preocupante), embora, em termos de estatuto de ameaça a nível da Europa, a espécie seja considerada "Em declínio", e classificada para Espanha como "Vulnerável". A sua tendência populacional é de declínio pela degradação e diminuição da área de habitat adequado, espacialmente, para a nidificação. Encontra-se protegido pela Convenção de Bona (Anexo II), Convenção de Berna (Anexo II) e pela Diretiva Aves (Anexo I). 

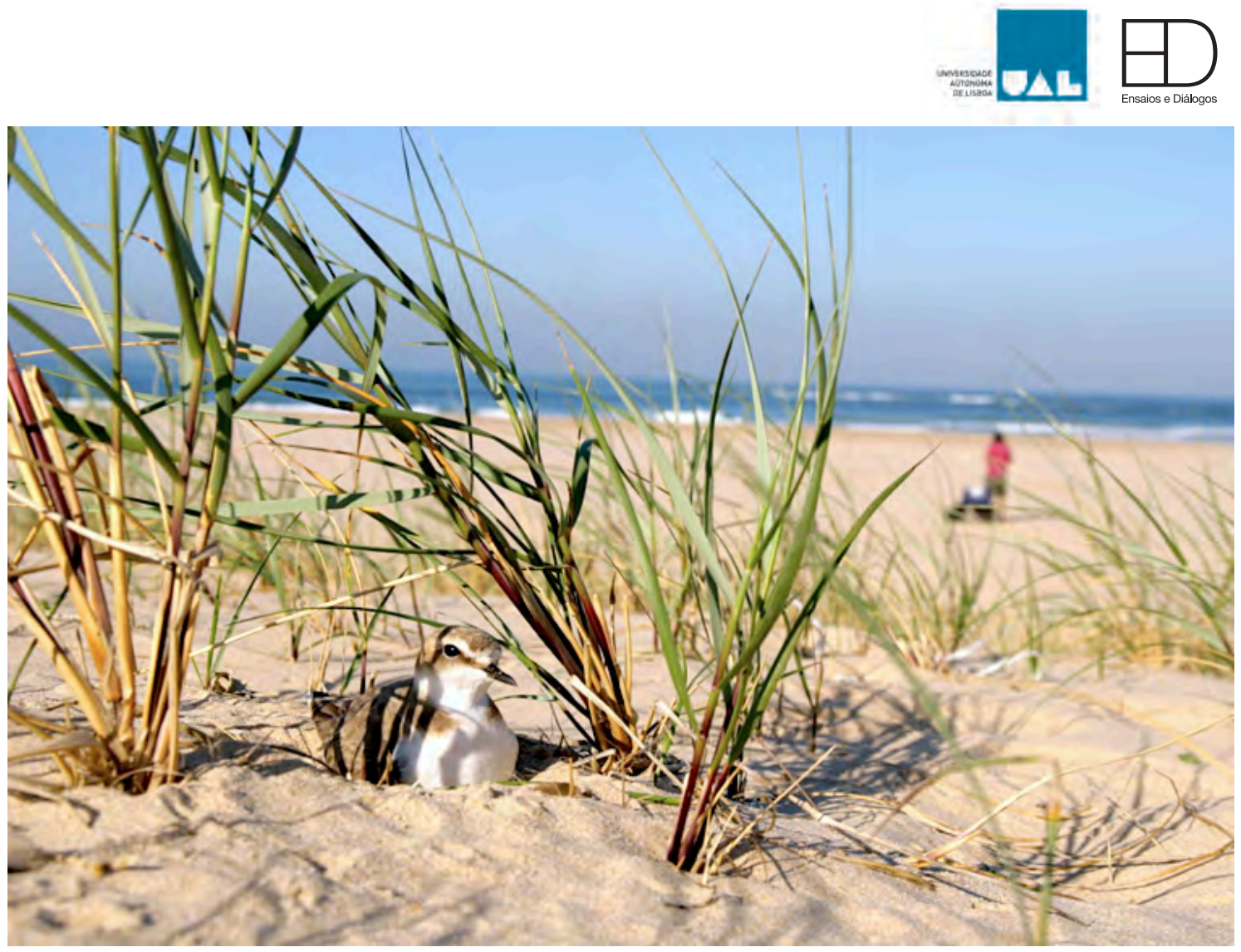

Figura 7 - O borrelho-de-coleira-interrompida (Charadrius alexandrinus) nidifica nas dunas da Cova do Vapor (Fonte: Banco de Imagens do património Natural de Almada CMA/DEGAS, 2011).

Na frente ribeirinha, é comum serem observadas espécies limícolas, como é o caso do ostraceiro (Haematopus ostralegus), espécie invernante classificada na categoria de Quase Ameaçada, ou o Maçarico-galego (Numenius phaeopus), espécie invernante Vulnerável. Destaca-se a ocorrência de falcão-peregrino (Falco peregrinus) no sistema dunar da Praia do 2 o Torrão.

Pela sua proximidade com a área da Mata de São João, que constitui a 2a maior área de pinhais litorais no concelho de Almada, esta área vê ainda ser acrescentada à sua lista de espécies frequentes, rapinas como as águias-de-asa-redonda (Buteo), as Corujas-do-Mato (Strix aluco) e Corujas-das-torres (Tyto alba).

No caso dos mamíferos, são frequentes os coelhos-bravos (Oryctolagus cuniculus) e existem registos de Saca-rabos (Herpestes ichneumon), o que indica que a dimensão e recursos existentes é suficiente para albergar espécies mais exigentes em termos ecológicos. 


\subsubsection{Os sistemas praia-duna e os serviços ambientais}

Por serem zonas de transição entre o meio terrestre e o meio aquático, estes territórios funcionam, de forma dinâmica, entre vários habitats e, por isso, quando se estuda ou trabalha nestes territórios, trabalha-se sobre o sistema praia-duna que inclui:

-o sistema dunar;

-a praia emersa;

-a praia submersa.

Estas 3 áreas funcionam como uma grande unidade sedimentar entre as quais as areias se movem, em função das pressões e dos fatores incidentes:

-climáticos e oceanográficos (ondas, correntes, marés, vento, chuva, tempestades, sobrelevação marinha);

-biológicos e ambientais (espécies nativas, espécies exóticas, poluição, incêndios):

-antrópicos (construções, pisoteio, dragagens).

É essencial que os sistemas praia-duna apresentem boa resiliência face às perturbações incidentes, que são caraterísticas deste território. Se, por um lado, têm de ter capacidade para absorver a perturbação sem perder totalmente a sua estrutura e função (ex. em situações mais intensas, os efeitos erosivos de uma tempestade podem causar a rutura ou destruição de um sistema dunar), por outro lado, têm de ser capazes de recuperar a seguir a essa perturbação.

Quando os sistemas praia-duna estão muito degradados por causas naturais e/ou antrópicas, a sua resiliência face a eventos climáticos é menor e é mais difícil voltarem a adquirir as condições de funcionamento e estrutura capazes de fornecer serviços ambientais tão importantes como:

-proteção costeira e dos territórios interiores;

-recarga do aquífero costeiro e manutenção do nível freático na planície costeira entre a Trafaria e a Fonte da Telha;

-conservação da biodiversidade de suporte aos ecossistemas marinhos e terrestres;

-atratividade balnear;

-passeio, recreio e lazer;

-suporte de atividades económicas como restauração e empresas de turismo;

-pesca;

-etc.

Por atualmente se verificar uma menor qualidade do fornecimento destes serviços, como, por exemplo, rebaixamento do aquífero, haver menos biodiversidade, o sistema de vistas e os caminhos não serem tão interessantes ou atrativos, corre-se o risco de ser ultrapassado o limiar de capacidade de recuperação e de estes serviços deixarem mesmo de ser prestados, destacando-se naturalmente a proteção costeira. 


\subsubsection{Flora e vegetação}

Nas zonas costeiras arenosas, os ecossistemas têm como variáveis ambientais um conjunto de fatores ambientais limitantes para a vida terrestre, e as espécies que conseguem habitar nestas zonas limite apresentam adaptações a estes fatores edafoclimáticos e à sua dinâmica que as tornam muito específicas e fortemente associadas aos habitats costeiros.

A vegetação que se instala nos cordões dunares afeta, de forma determinante, a morfologia das dunas costeiras, não só pela sua capacidade de fixar as areias, mas também por alterar os fluxos de vento e das areias que esse vento transporta (Seoane, Fernández, Pascual, 2007).

A vegetação que coloniza as dunas costeiras distribui-se primordialmente em função das condições ambientais locais, determinadas pelas variações das caraterísticas geomorfológicas e edáficas, da influência marinha e da salsugem transportada pelos ventos e, portanto, dependendo das adaptações morfológicas e fisiológicas que possuem relativamente a estes gradientes ambientais, definindo uma zonação, desde as comunidades que se estabelecem próximo do mar, até às que colonizam as dunas interiores.

O processo de colonização e construção das dunas costeiras inicia-se assim na altapraia através de germinação ou desenvolvimento de frações vegetativas de plantas trazidas pelo mar e vento, como rizomas ou estolhos que, à medida que se vão desenvolvendo, vão intersetando os grãos de areia, começando a formar-se montículos que crescem à medida que crescem também as plantas, formando uma pré-duna baixa já com capacidade de fixação de areia e de novas plantas (Seoane, Fernández, Pascual, 2007).

As espécies capazes de estruturar as dunas frontais são as gramíneas Elymus farctus (feno-das-areias) e Ammophila arenaria (estorno), cujo crescimento é estimulado pelo soterramento (Seoane, Fernández, Pascual, 2007), formando sequencialmente, da praia para o interior, as dunas embrionárias e as dunas primárias. Estas constituem por isso as principais espécies para introdução ou reforço das dunas degradadas.

Para além destas espécies, encontram-se no elenco de espécies dunares, um conjunto de espécies coadjuvantes da retenção sedimentar, por intersetarem e reduzirem a velocidade do vento, produzir elevadas quantidades de matéria orgânica e alterar localmente as condições edáficas e microclimáticas que favorecem a instalação de outras plantas. Destacam-se Crucianella maritima, Artemisia campestris subsp. maritima, Armeria pungens, Lotus creticus, Euphorbia paralias, Helichrysum italicum, entre outras espécies caraterísticas da duna primária, vale interdunar e duna secundária.

Para caraterização da vegetação e zonação da biodiversidade vegetal na Cova do Vapor foram realizados 2 transetos transversais à linha de Costa na Praia da Cova do Vapor, onde o sistema dunar apresenta uma extensão de $183 \mathrm{~m}$, e uma cobertura média do solo pela vegetação de cerca de $90 \%$, estando representadas 16 espécies. 


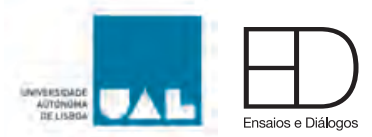

Este troço costeiro apresenta boa equitabilidade de distribuição das espécies, o que significa que a sua distribuição responde essencialmente aos fatores ambientais.

Devido aos fortes ventos incidentes e à constante entrada de sedimentos para o sistema dunar, este mantém ainda uma duna com características jovens e em crescimento, com uma extensa duna embrionária com elevada cobertura de Elymus farctus, sem que se tenha ainda formado uma duna primária estável que já seria dominada pela Ammophila arenaria. Encontram-se algumas pequenas áreas onde a estabilidade sedimentar já permitiu a instalação da Ammophila arenária, mas a frente dunar mantém-se com declive suave e dominada pelo Elymus farctus. A zona interior é mais pressionada que a duna frontal, apresentando espécies introduzidas como Arundo donax, Aloe arborescens, Acacia melanoxilon e Carpobrotus edulis, este último com elevada cobertura.

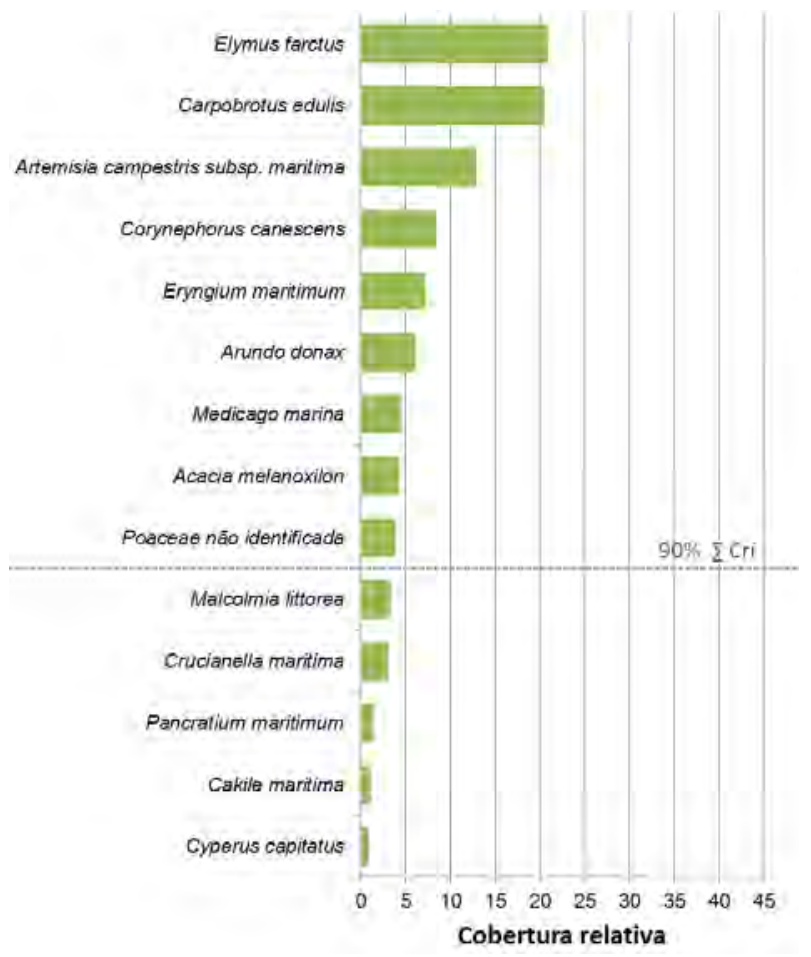

Figura 8 - Biodiversidade e cobertura relativa de cada espécie no sistema dunar da Praia da Cova do Vapor.

Na Primeira Praia, o Sistema dunar encontra-se muito degradado, estando as dunas primárias apenas constituídas por alguns indivíduos de Ammophila arenaria dispersos, cuja área tem diminuído em função da evolução do pisoteio e degradação da duna e por primocolonizadores anuais como Cakile marítima e Elymus farctus que vão aparecendo nas áreas em que a pressão antrópica é menor durante o inverno. 


\subsubsection{Riscos e vulnerabilidades}

No concelho de Almada, especialmente no troço mais a norte, onde se inserem as praias oceânicas da Cova do Vapor e de São João da Caparica, existe uma grande célula sedimentar que se encontra com carência de sedimentos, razão pela qual tem havido a necessidade nos últimos anos de realizar momentos de alimentação artificial das praias.

Para a conservação ou reforço da resiliência dos sistemas naturais e aumento de a capacidade destes sistemas fornecerem o serviço ambiental de proteção costeira, é necessário apoiar a capacidade do sistema natural lidar com a dinâmica natural e sazonal deste sistema praia - duna.

Assim, para que se possa definir quais são as áreas em que é possível atuar a curto, médio e longo prazo, é importante conhecer: 1) a vulnerabilidade atual do sistema praia - duna - "a causa"; 2) as pressões ambientais (climáticas e oceanográficas, biológicos e ambientais e antrópicas) - "os agentes perturbadores"; 3) os fatores que definem a dinâmica deste território - "as ferramentas disponíveis".

\section{Análise dos agentes forçadores e da vulnerabilidade do sistema praia-duna}

No caso das praias da Cova do Vapor, existem 2 zonas: Praia da Cova do Vapor, onde o sistema dunar é extenso e a duna se encontra em crescimento e tem uma biodiversidade muito interessante; e o sistema dunar no extremo norte, associado à Primeira Praia, muito degradado, com vulnerabilidade muito elevada aos fatores climáticos (tempestades), ambientais (exóticas) e antrópicos (pisoteio). A sua resiliência às perturbações é muito baixa e, portanto, presta poucos serviços ambientais, designadamente proteção costeira. A incapacidade de reter sedimentos transportados pelo vento conduz a que esses sedimentos sejam perdidos do sistema e transportados para a zona urbana e criem situações de conflito com os moradores e visitantes.

A vulnerabilidade atual do sistema praia-duna na Cova do Vapor foi calculada através da aplicação de uma checklist proposta por Pinto da Silva (2015) para avaliação do Índice de Vulnerabilidade Costeira (IVC): 
Primeira Praia

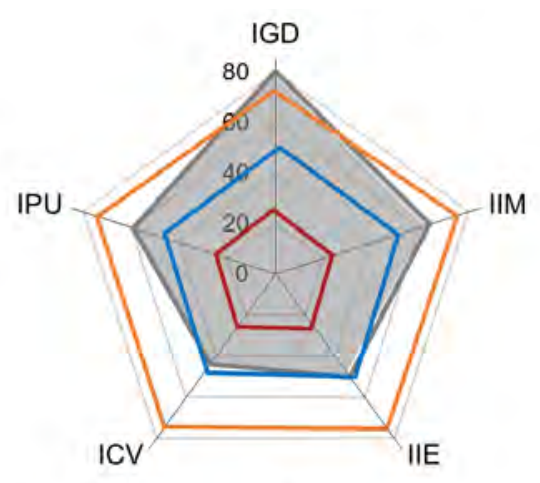

IVC $=60 \%$
Praia da Cova do Vapor

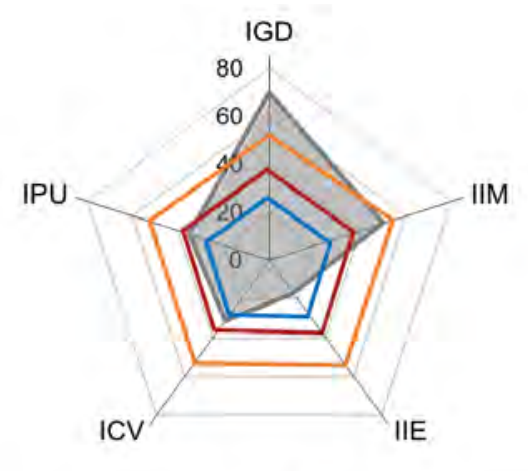

$\operatorname{IVC}=\mathbf{4 1 \%}$

Indice de Vulnerabilidade

Ordenamento e Gestāo

Obstáculos à Livre Dinâmica Transgressiva da Duna

Atratividade Recreativa e Turistica

Figura 9 - Índice de Vulnerabilidade Costeira para as praias da Cova do Vapor.

A Praia da Cova do Vapor tem um Índice de Vulnerabilidade Costeira de 41\% (Baixo a Médio). O sistema dunar está em bom estado, apresenta boa biodiversidade e cobertura vegetal. Apresenta já alguma pressão de uso com o aumento do número e da profundidade dos caminhos causando erosão, crescimento de chorão (Carpobrotus edulis) e outras espécies invasoras e afastando a biodiversidade de vertebrados e invertebrados. $O$ agente principal da erosão é a pressão antrópica. $O$ sistema dunar secundário não apresenta edificações, reduzindo o conflito com a movimentação do sistema dunar para tardoz associado ao previsível recuo da linha de costa. Permite assim acomodar uma translação para o interior desta proteção costeira natural. Por ser uma praia com fácil acesso e parqueamento e com concessão de apoio de praia poderá esperar-se um aumento da perturbação de uso, pelo que são necessárias medidas de gestão e de ordenamento para prevenir evolução da perturbação.

No gráfico pode ver-se que os arcos dos "Obstáculos à Livre Dinâmica Transgressiva da Duna" e a "Atratividade Recreativa e Turística" são maiores que o polígono do Índice de Vulnerabilidade Costeira. Espera-se, assim, que estes fatores possam vir a aumentar o Índice de Vulnerabilidade Costeira neste troço a médio prazo.

O principal desafio que levanta é permitir visitação sem degradação.

A Primeira Praia tem um Índice de Vulnerabilidade Costeira de 60\% (Elevado). 0 sistema dunar está degradado, quase ausente, pela artificialização e atravessamento pedonal intenso, assim como pela circulação de veículos, eliminando o cordão dunar em mais de $50 \%$ da largura da praia. A vegetação é esparsa. 


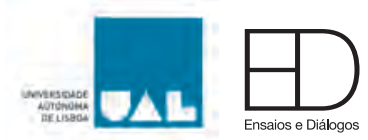

Este sistema praia-duna é muito vulnerável aos efeitos climáticos (tempestades), marinhos (ondulação, correntes e erosão), ambientais (espécies invasoras) e antrópicos (pisoteio). A incapacidade do sistema reter sedimentos transportados pelo vento conduz a que esses sedimentos sejam perdidos e transportados para a zona urbana, criando situações de conflito com os moradores e visitantes.

No gráfico pode ver-se que o arco do "Ordenamento e Gestão" é maior que todos os outros polígonos, mostrando a urgência e necessidade de serem efetuadas medidas de ordenamento e gestão deste território. Estas ações devem focar-se principalmente na recuperação do sistema geomorfológico e sedimentar e na redução da pressão de uso.

O maior desafio atual é conciliar o uso balnear e pesca com recuperação da integridade do cordão dunar.

\begin{tabular}{|c|c|c|}
\hline & Praia da Cova do Vapor & Primeira Praia \\
\hline $\begin{array}{l}\text { Índice } \\
\text { Geomorfológico } \\
\text { e Sedimentar do } \\
\text { sistema dunar } \\
\text { (IGD) }\end{array}$ & $\begin{array}{l}\text { IGD }=70 \% \\
\text { O sistema dunar é extenso com } \\
\text { cordão dunar frontal forte e em } \\
\text { crescimento. }\end{array}$ & $\begin{array}{l}\text { IGD }=80 \% \\
\text { O sistema dunar é estreito e } \\
\text { encontra-se muito degradado. } 0 \\
\text { cordão dunar frontal está } \\
\text { eliminado em mais de } 50 \% \text { da } \\
\text { largura da praia. }\end{array}$ \\
\hline $\begin{array}{l}\text { Índice de } \\
\text { Incidência } \\
\text { Marinha (IIM) }\end{array}$ & $\begin{array}{l}\mathrm{IIM}=50 \% \\
\text { Efeitos da ação marinha } \\
\text { minorados pela praia muito } \\
\text { comprida }\end{array}$ & $\begin{array}{l}\text { IIM }=64 \% \\
\text { Efeitos marinhos erosivos fortes } \\
\text { associados aos fundos profundos } \\
\text { imediatamente adjacentes à área } \\
\text { de praia intertidal. }\end{array}$ \\
\hline $\begin{array}{l}\text { Índice de } \\
\text { Incidência Eólica } \\
\text { (IIE) }\end{array}$ & $\begin{array}{l}\text { IIE = } 17 \% \\
\text { Não existem sinais de erosão } \\
\text { eólica significativos }\end{array}$ & $\begin{array}{l}\text { IIE }=50 \% \\
\text { Erosão eólica muito significativa } \\
\text { por ausência de plantas que } \\
\text { retenham as areias transportadas } \\
\text { pelo vento }\end{array}$ \\
\hline $\begin{array}{l}\text { Índice das } \\
\text { Características da } \\
\text { Vegetação (ICV) }\end{array}$ & $\begin{array}{l}\text { ICV }=31 \% \\
\text { Boa biodiversidade e zonação. } \\
\text { Cobertura vegetal densa. }\end{array}$ & $\begin{array}{l}\mathrm{ICV}=44 \% \\
\text { Existem apenas espécies que } \\
\text { resistem à perturbação e aos } \\
\text { fatores climáticos e de dinâmica } \\
\text { sedimentar mais extremos }\end{array}$ \\
\hline $\begin{array}{l}\text { Índice de Pressão } \\
\text { de Uso (IPU) }\end{array}$ & $\begin{array}{l}\text { IPU = } 35 \% \\
\text { Pressão de uso média, rede de } \\
\text { caminhos pouco significativa }\end{array}$ & $\begin{array}{l}\text { IPU = 59\% } \\
\text { Pressão de uso elevada por } \\
\text { pisoteio e veículos atravessam o } \\
\text { sistema dunar }\end{array}$ \\
\hline $\begin{array}{l}\text { Índice de } \\
\text { Vulnerabilidade } \\
\text { Costeira (IVC) } \\
\text { Média das } \\
\text { vulnerabilidades } \\
\text { a cada um dos } \\
\text { fatores }\end{array}$ & $\begin{array}{l}\text { IVC }=41 \% \\
\text { Índice de Vulnerabilidade } \\
\text { Costeira Baixo a Médio. } \\
\text { Sistema dunar em bom estado, } \\
\text { boa biodiversidade e cobertura } \\
\text { vegetal. Pressão antrópica e de } \\
\text { uso média. }\end{array}$ & $\begin{array}{l}\text { IVC }=60 \% \\
\text { Índice de Vulnerabilidade } \\
\text { Costeira Elevado. } \\
\text { Sistema dunar degradado, } \\
\text { pisoteio e veículos atravessam a } \\
\text { duna eliminando o cordão dunar } \\
\text { em mais de } 50 \% \text { da largura da } \\
\text { praia. Vegetação esparsa. }\end{array}$ \\
\hline
\end{tabular}




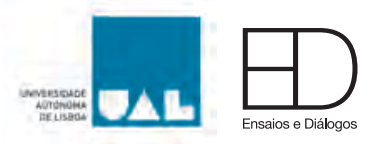

\begin{tabular}{|l|l|l|}
\hline $\begin{array}{l}\text { Obstáculos à } \\
\text { Livre Dinâmica } \\
\text { Transgressiva da } \\
\text { Duna (OTD) }\end{array}$ & $\begin{array}{l}\text { OTD = 25\% } \\
\text { O sistema dunar secundário não } \\
\text { apresenta edificações, reduzindo } \\
\text { o conflito com a movimentação } \\
\text { do sistema dunar para tardoz } \\
\text { associado ao previsível recuo da } \\
\text { linha de costa. }\end{array}$ & $\begin{array}{l}\text { OTD = 50\% } \\
\text { A incapacidade do sistema reter } \\
\text { sedimentos transportados pelo } \\
\text { vento conduz a que esses } \\
\text { sedimentos sejam transportados } \\
\text { para a zona urbana e criem } \\
\text { situações de conflito com os } \\
\text { moradores e visitantes. }\end{array}$ \\
\hline $\begin{array}{l}\text { Atratividade } \\
\text { Recreativa e } \\
\text { Turística (AT) }\end{array}$ & $\begin{array}{l}\text { AT = 38 \% } \\
\text { Por ser uma praia com fácil } \\
\text { acesso e parqueamento e com } \\
\text { concessão de apoio de praia } \\
\text { poderá esperar-se um aumento } \\
\text { da perturbação de uso. }\end{array}$ & $\begin{array}{l}\text { AT =38\% } \\
\text { Embora sem vigilância, a } \\
\text { proximidade à zona urbana } \\
\text { fornece um conjunto de serviços } \\
\text { que a tornam atrativa. }\end{array}$ \\
\hline $\begin{array}{l}\text { Índice de } \\
\text { Ordenamento e } \\
\text { Gestão (IOG) }\end{array}$ & $\begin{array}{l}\text { IOG = 55\% } \\
\text { São necessárias medidas de } \\
\text { gestão e de ordenamento para } \\
\text { prevenir evolução da perturbação }\end{array}$ & $\begin{array}{l}\text { IOG = 75\% } \\
\text { são urgentes mão e recuperação dos } \\
\text { ecossistemas para reduzir a } \\
\text { vulnerabilidade. }\end{array}$ \\
\hline
\end{tabular}

Tabela 2 - Caraterização do Índice de Vulnerabilidade Costeira e dos Índices de Evolução da Vulnerabilidade.

\subsection{Enquadramento teórico e legislativo}

\subsubsection{Instrumentos de Gestão do Território em vigor}

A localização da Cova do Vapor obriga a que, segundo o RJIGT - Regime Jurídico dos Instrumentos de Gestão do Território (Decreto-Lei n.ㅇ 80/2015, de 14 de maio), este território esteja abrangido por dois instrumentos de gestão do território com incidência local, um de natureza municipal e vinculativo para os particulares, o PDMA Plano Diretor Municipal de Almada, e um de natureza especial, o POC ACE, Programa da Orla Costeira Alcobaça - Cabo Espichel, vinculativo para as entidade públicas, que têm de o integrar nos seus instrumentos. Este último foi recentemente aprovado (Resolução do Conselho de Ministros n. 66/2019, de 11 de abril), vindo substituindo o anterior POOC Sintra - Sado - Plano de Ordenamento da Orla Costeira Sintra - Sado (Resolução do Conselho de Ministros n. 86/2003, de 25 de junho). Trata-se de um programa que abrange uma extensão de $224 \mathrm{~km}$ da orla costeira, em 12 concelhos. Segundo o RJIGT, "As normas dos programas territoriais que, em função da sua incidência territorial urbanística, condicionem a ocupação, uso e transformação do solo são obrigatoriamente integradas nos planos territoriais" (n. 5 do Art.o 3으), pelo que o PDMA terá de integrar as diretrizes programáticas agora definidas.

O PDMA em vigor data de 1997 (Resolução do Conselho de Ministros n.o 5/97, de 14 de janeiro); não obstante terem sido já realizados os estudos para a sua revisão, que são tidos aqui como referência, o novo plano não está ainda aprovado. 


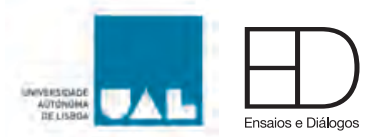

Em ambos os documentos, a Cova do Vapor é classificada como uma área de risco muito elevado, com diretrizes de ordenamento conducentes à sua renaturalização. Assim, o PDM em vigor classificava esta área (inserida na UNOP 7 - Trafaria-Costa da Caparica) dentro da categoria "Espaços culturais e naturais", com a indicação de que "A área abrangida pelo núcleo clandestino da Cova do Vapor deve ser objecto de estudo com vista à sua renaturalização" (Art.o 51으).

O POOC anterior classificava a Cova do Vapor como uma praia não urbana de uso intensivo, correspondendo a praia afastada de núcleos urbanos, mas sujeita a forte procura, não a diferenciando, neste aspeto, da vizinha praia de São João. Neste plano apenas era classificada como praia (e sujeita a plano de praia) e a área a sul do núcleo urbano, contígua à praia de São João da Caparica. O areal a norte, entre os dois pontões da Cova do Vapor, correspondendo ao que temos vindo a designar por Primeira Praia, era designado por Baía da Cova do Vapor.

Os estudos para a elaboração do PDMA consideram a Cova do Vapor um "espaço urbano precário", enfatizam a vulnerabilidade desta área à erosão e à suscetibilidade de galgamento pelo mar e o Quadro Prévio ao Ordenamento (novembro 2015) identifica-a como "Área problema".

Neste documento, é proposto "Potenciar e promover o corredor verde que se inicia no vale que acompanha a vertente norte do IC20, passa pela área do ex-Onda Parque, segue pelo Forte de Alpenas, Bateria da Raposeira, faz a ligação às Abas da Raposeira e se desenvolve tanto na direção da Mata dos Franceses como da ribeira da Enxurrada. E criar o corredor verde ribeirinho Trafaria - Cova do Vapor, em articulação com o corredor atlântico associado à área PPAFCC e Matas de Sesimbra" (p. 98) e a "Renaturalização de determinadas áreas ocupadas de génese ilegal, designadamente as que pela sua localização, especificidades e vulnerabilidades deverão ser naturalizadas de forma a preservar e mitigar riscos naturais. Exemplo disso é a Cova do Vapor, a frente ribeirinha junto ao 10 e 20 Torrão, a área ocupada do Pica Galo com sobreposição à Reserva Ecológica Nacional (REN) e a área da Fonte da Telha" (p. 99). No entanto, é referida a necessidade de estudar este território para enquadrar estas estratégias. É ainda relevante que, do processo de participação pública desenvolvido, tenha sido enunciado como um dos principais problemas a necessidade de "desenvolvimento de estratégias de inclusão social e territorial, bem como de requalificação e reconversão urbana" para esta área (p. 180).

Esta linha de análise, argumentação e regulamentação é seguida pelo POC ACE. Na Introdução da publicação refere-se o seguinte:

"Por sua vez, os troços de litoral arenoso encontram-se sujeitos a um elevado risco de galgamento, inundação e erosão costeira. Por um lado, o regime de agitação marítima induz um transporte sedimentar litoral muito significativo e, por outro, a diminuição do fornecimento de sedimentos ao litoral provocado pelas atividades humanas nas bacias hidrográficas e na zona costeira, conduziu a um elevado défice sedimentar, a que se associam problemas de erosão muito significativos. Neste contexto, a perigosidade é extrema em troços como o setor costeiro a sul do aglomerado da 


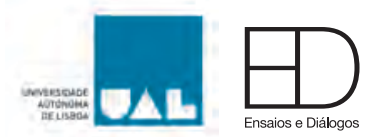

Nazaré, nos troços de costa baixa e arenosa do concelho de Peniche, na Praia da Areia Branca e, especialmente, no arco da Cova do Vapor à Fonte da Telha." (RCM n.o 66/2019)

O Relatório Ambiental elaborado durante a execução do POC ACE reafirma da localização de "perigosidade extrema" e "grande vulnerabilidade com uma evolução regressiva com perda contínua de sedimentos" (p. 39). Refere ainda a sua relevância para a avifauna marinha, nomeadamente com a ocorrência de espécies consideradas raridades em Portugal. Considera este um aglomerado urbano em situação de risco extremo, identificando a sua situação crítica ao nível da proteção costeira e considera que "deverá ser ponderada a necessidade de relocalização ou realojamento da população e renaturalização desses territórios, através de estudo a realizar, conforme preconizado em sede de PDM" (p. 128).

Para a Cova do Vapor, são definidas faixas de salvaguarda, quer para o galgamento, inundação e erosão costeira (Mapas 3 e 4), que confirmam esta vulnerabilidade. No entanto, esta constatação do risco e perigosidade é apresentada como um problema, mas também como um desafio, cuja resolução não está ainda completamente estudada e definida: "O sector entre a Cova do Vapor e a Costa da Caparica constitui um dos maiores desafios de proteção da orla costeira nacional e o principal ponto crítico de proteção da área de intervenção. A necessidade de intervir regularmente neste território faz com que esta frente de atlântica tenha absorvido $18,4 \%$ do total de investimentos em defesa costeira realizados em Portugal, entre 1995 e 2014.

Acresce que, a longo prazo (mais de 50 anos), com a sobrelevação do nível das águas do mar, é expectável que a dinâmica regressiva recrudesça, obrigando à ponderação de outras alternativas na estratégia de adaptação. Neste quadro, independentemente da estratégia de intervenção se focar na alimentação artificial das praias, importa iniciar um processo de estudo que conduza, em caso de necessidade, no médio-longo prazo, à criação de novas estruturas de defesa nos locais em situação mais gravosa. 0 estudo de avaliação deverá centrar-se em zonas piloto, em áreas críticas (nacionais e/ou internacionais), onde estejam ou venham a ser testadas soluções inovadoras. 0 estudo a desenvolver relevará o desempenho dos casos piloto permitindo avaliar da adequabilidade da utilização da solução, em caso de necessidade, na Praia de São João." (p. 169)

Passando do diagnóstico à programação e proposta de linhas estratégicas e de ação, o POC ACE, no documento Classificação e programação de praias, define a praia da Cova do Vapor como pertencente à tipologia periurbana, com uma área útil balnear de $11895 \mathrm{~m} 2$, e uma capacidade de carga de 1200 pessoas (p. 121). 
MAPA 3 - FAIXA DE SALVAGUARDA AO GALGAMENTO E INUNDAÇÃo COSTEIRA*

ESC. 1/5000

Nível I

Nível II

*Programa da Orla Costeira Alcobaça - Cabo Espichel

Planta de Modelo Territorial (adaptado)

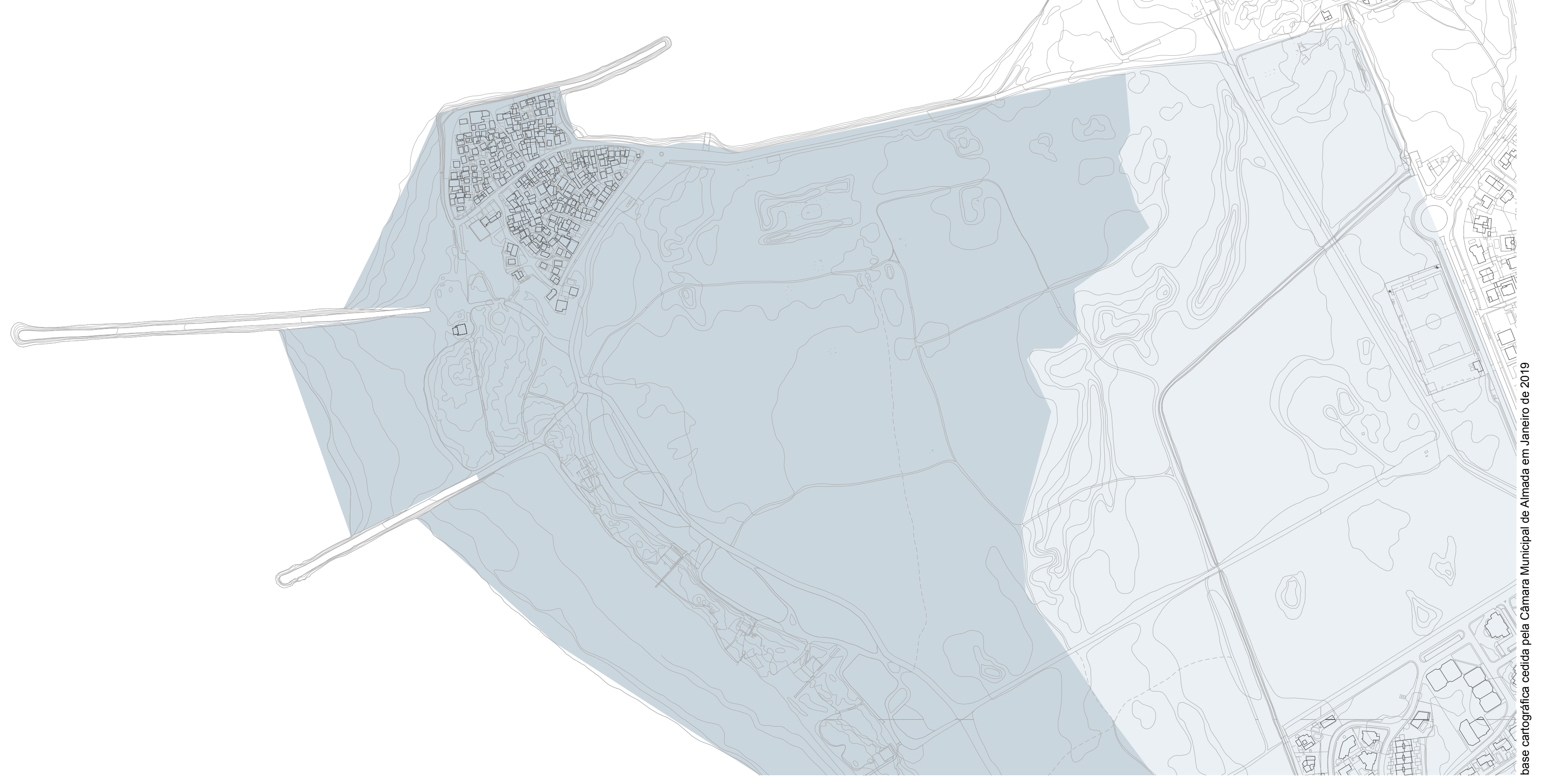


MAPA 4 - FAIXA DE SALVAGUARDA À EROSÃO COSTEIRA*

ESC. $1 / 5000$

Nível I

Nível II

*Programa da Orla Costeira Alcobaça - Cabo Espichel

Planta de Modelo Territorial (adaptado) 


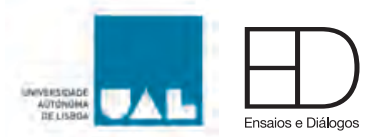

No Programa de Execução e Plano de Financiamento são definidos objetivos e linhas estratégicas e apresentadas um conjunto de medidas para o cumprimento dos objetivos. A tabela seguinte sistematiza a informação relativa à Cova do Vapor. É importante referir que as ações que dizem respeito à praia são direcionadas para a Praia da Cova do Vapor, sem referir a Primeira Praia, enquanto as restantes são destinadas a toda a área.

\begin{tabular}{|c|c|c|}
\hline Objetivo & Linha estratégica & Ação (nível de prioridade) \\
\hline \multirow[t]{2}{*}{$\begin{array}{l}\text { Objetivo Estratégico } \\
\text { Setorial } 1 \text { Riscos } \\
\text { Costeiros - Prevenir } \\
\text { e reduzir os riscos } \\
\text { costeiros e a } \\
\text { vulnerabilidade às } \\
\text { alterações climáticas }\end{array}$} & $\begin{array}{l}\text { Linha Estratégica } 3 \\
\text { "Promover a Investigação e } \\
\text { Desenvolvimento de Novas } \\
\text { Abordagens de Proteção } \\
\text { Costeira e de Gestão } \\
\text { Integrada da Orla Costeira" }\end{array}$ & $\begin{array}{l}\text { Ação } 10 \text { - Demolição e remoção de } \\
\text { estruturas localizadas em Faixa de } \\
\text { Salvaguarda - Nível I e II no } \\
\text { aglomerado da Cova do Vapor e } \\
\text { renaturalização da área (incluindo } \\
\text { Implementação de ações de retirada } \\
\text { planeada) - 2021/2028 (prioridade } \\
\text { baixa [3]) }\end{array}$ \\
\hline & $\begin{array}{l}\text { Linha Estratégica } 4 \\
\text { "Assegurar a Fruição } \\
\text { Pública em Segurança do } \\
\text { Domínio Público Marítimo" }\end{array}$ & $\begin{array}{l}\text { Ação } 46 \text { - Intervenção de manutenção } \\
\text { e reforço do cordão dunar entre a } \\
\text { Cova do Vapor e a Costa de Caparica e } \\
\text { entre a Praia da Saúde e a Praia do } \\
\text { Infante (prioridade elevada [1]) }\end{array}$ \\
\hline \multirow{3}{*}{$\begin{array}{l}\text { Objetivo Estratégico } \\
\text { Transversal } 1 \text { Praias } \\
\text { - Valorizar e } \\
\text { qualificar as praias } \\
\text { marítimas enquanto } \\
\text { recurso natural, } \\
\text { social e económico }\end{array}$} & \multirow{2}{*}{$\begin{array}{l}\text { Linha Estratégica } 1 \text { - } \\
\text { Assegurar a Preservação } \\
\text { das Praias, dos Sistemas } \\
\text { Dunares e das Arribas } \\
\text { associadas, bem como dos } \\
\text { Espaços Naturais e da } \\
\text { Identidade da Paisagem } \\
\text { Costeira }\end{array}$} & $\begin{array}{l}\text { A218 - Intervenções de requalificação } \\
\text { / valorização (PIP da Cova do Vapor) } \\
\text { (prioridade elevada [1]) }\end{array}$ \\
\hline & & $\begin{array}{l}\text { A300 - Intervenção de requalificação } \\
\text { de estacionamento (PIP da Cova do } \\
\text { Vapor) (prioridade elevada [1]) }\end{array}$ \\
\hline & $\begin{array}{l}\text { Linha Estratégica } 3 \text { - } \\
\text { Melhorar a Qualidade de } \\
\text { Acessos e Receção de } \\
\text { Utilizadores, } \\
\text { designadamente da } \\
\text { População Deficiente }\end{array}$ & $\begin{array}{l}\text { A332 - Criação de acessos pedonais } \\
\text { (PIP da Cova do Vapor (prioridade } \\
\text { elevada [1]) }\end{array}$ \\
\hline
\end{tabular}

Tabela 3 - Identificação dos objetivos, linhas estratégicas e ações do POC ACE para a Cova do Vapor.

Na caraterização das ações a realizar, o projeto "Realojar população em Faixa de Salvaguarda (Nível I e II) em situação de elevada perigosidade", é justificado da seguinte forma:

"A Cova do Vapor desenvolveu-se no extremo noroeste do concelho de Almada, mantendo atualmente características piscatórias e balneares e potencial turístico e recreativo relevantes. Em diversos momentos históricos a vila foi recuada em função do avanço do mar, sendo novamente necessária à sua relocalização para fora das ZAM. A relocalização deve ser estudada de forma a qualificar as infraestruturas e serviços num contexto de valorização social e turística apoiada nas características piscatórias e balneares informais deste aglomerado. Devido ao contínuo e generalizado défice 


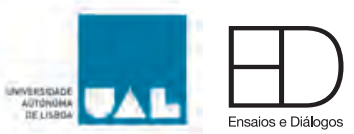

sedimentar, a tendência evolutiva na zona da Cova do Vapor corresponde à diminuição progressiva da dimensão do areal. Apesar da alimentação artificial prevista para este trecho costeiro, o risco muito elevado e o contexto de progressivo agravamento da frequência de ocorrência de galgamentos e inundações e do potencial de danos, fundamenta a necessidade de ponderar a relocalização para um local recuado." (p. 77)

O aspeto mais interessante desta contextualização reside no facto de, pela primeira vez, se mencionar a possibilidade de relocalização do aglomerado urbano para fora das ZAM (Zonas Ameaçadas pelo Mar), assumindo este como resultado de um processo dinâmico, com potencial de resolução.

Da análise, é de referir que o POC ACE considera como prioridade elevada as ações com o objetivo de manutenção e requalificação do cordão dunar (ações 46, 218, 300 e 332), ações estas que podem ser levadas a cabo com maior rapidez, atribuindo prioridade baixa à renaturalização, realojamento e retirada do local (ação 10).

De uma forma geral são definitivamente abandonadas as estratégias de intervenção de engenharia pesada, como as que foram feitas no passado, e todas as ações se encaminham para soluções de proteção e renaturalização como forma de proteção dos territórios face aos riscos, incluindo alimentação artificial para manutenção da carga sedimentar e a proteção dos terrenos interiores.

É também de referir que a exposição ao risco é superior durante o inverno, com a ocorrência de tempestades marítimas, e que a pressão antrópica se sente, sobretudo no verão, com o uso balnear, pelo que as ações previstas têm de precaver quer a pressão natural, quer a pressão antrópica.

Um aspeto que importa salientar é que, dada a natureza destes instrumentos (PDMA e $\mathrm{POC})$, destinados à gestão e ordenamento do território, assumida como uma competência do Estado central ou das autarquias, nunca é tida em consideração a capacidade de os cidadãos poderem ser agentes de transformação positiva do seu território.

Por fim, importa ainda fazer uma menção à Reserva Ecológica Nacional. Estabelecida em 1983 como instrumento de proteção dos recursos naturais de gestão do território

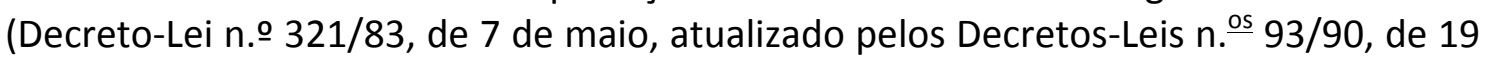
de março, 213/92, de 12 de outubro, e 180/2006, de 6 de setembro), é parte integrante das condicionantes e propostas dos planos e programas cujas áreas são por ela abrangidas e assume o estatuto de restrição de utilidade pública. 0 regime em vigor, definido em 2008 (Decreto-Lei n.o 166/2008, de 22 de agosto), foi recentemente alterado (Decreto-Lei n. 124/2019, de 28 de agosto), reforçando as preocupações com as áreas de risco e com os impactes das alterações climáticas. Neste contexto, as dunas costeiras (divididas entre litorais e interiores) merecem algum destaque (Anexo I) e é especificada, para as dunas costeiras, a importância das funções de barreira contra fenómenos de erosão e galgamento oceânico, associados a tempestades ou tsunami, e de erosão eólica, armazenamento natural de areia para compensação da perda de sedimento provocada pela erosão e garantia dos processos de dinâmica costeira e da diversidade dos sistemas naturais, designadamente das características 


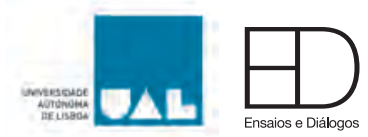

morfológicas, dos habitats naturais e das espécies da flora e da fauna (Anexo I, secção I, ponto 6). No âmbito destas funções, o decreto apenas permite que sejam realizados usos e ações que não coloquem em causa, cumulativamente, estas funções. É ainda referido que os usos e ações a existir têm de ter em conta "A deslocação expectável da linha de costa, no período de 100 anos, tendo em conta as condições geológicas locais" e "A Prevenção e redução do risco, garantindo a segurança de pessoas e bens".

\subsection{Enquadramento urbanístico}

A ocupação urbana da Cova do Vapor hoje observável data sobretudo nas décadas de 60 e 70 do século XX, tendo mantido, desde aí, alguma contenção espacial (apesar de alguma densificação interior). A macha urbana atual ocupa cerca de $35700 \mathrm{~m} 2$.

De assentamento disperso e informal junto à praia a aglomerado urbano denso de malha irregular (ver Mapa 2 - Área de estudo), a ocupação e urbanização da Cova do Vapor é uma história que, com atributos e especificidades próprias, decorre dos sucessivos avanços do mar em relação à terra e da progressiva artificialização da costa que, de forma mais evidente, ocorre durante a segunda metade do séc. XX nas duas margens da foz do Rio Tejo.

As vias de acesso à Cova do Vapor são escassas e, apesar da sinalização existente na Avenida Afonso de Albuquerque, pouco evidentes. Essa circunstância que, à partida, pode ser entendida com uma desvantagem para moradores e visitantes é, do ponto de vista da pressão balnear, uma mais-valia. Alguma dificuldade e desconhecimento em relação aos acessos, sobretudo quando comparada com a facilidade com que se acede a outras praias da Costa da Caparica, tem garantido um equilíbrio da carga durante a época balnear que, apesar da intensificação dos últimos anos, seria porventura mais crítica se o acesso automóvel fosse facilitado (Mapa 5 - Rede viária e estacionamento).

O acesso principal à localidade é feito por estrada asfaltada que, a partir da Avenida Afonso de Albuquerque, contorna o recinto das praias de São João da Caparica. Na maioria das vezes, o troço paralelo ao Rio Tejo é parcialmente ocupado por areia que galga da concentração de areia que se forma junto do enrocamento que delimita os depósitos da Pol Nato.

Ao chegar à Cova do Vapor, o prolongamento desta via de acesso estrutura a malha urbana do aglomerado e divide-o em dois. É nessa rua, designada Avenida António Martins Correia, com duas frentes de casas, que encontramos os negócios em funcionamento - cafés, padaria, mercearia e banca de roupa. A partir dessa rua principal temos acesso a uma via secundária, designada Rua Jorge Loureiro, a partir da qual acedemos à via que circunda a zona norte e noroeste do aglomerado urbano, designada Avenida João Dias Mourinha. 
MAPA 5 - REDE VIÁRIA E ESTACIONAMENTO

ESC. $1 / 5000$

Via principal

Via secundária

Via privada

Estacionamento

Estacionamento pago

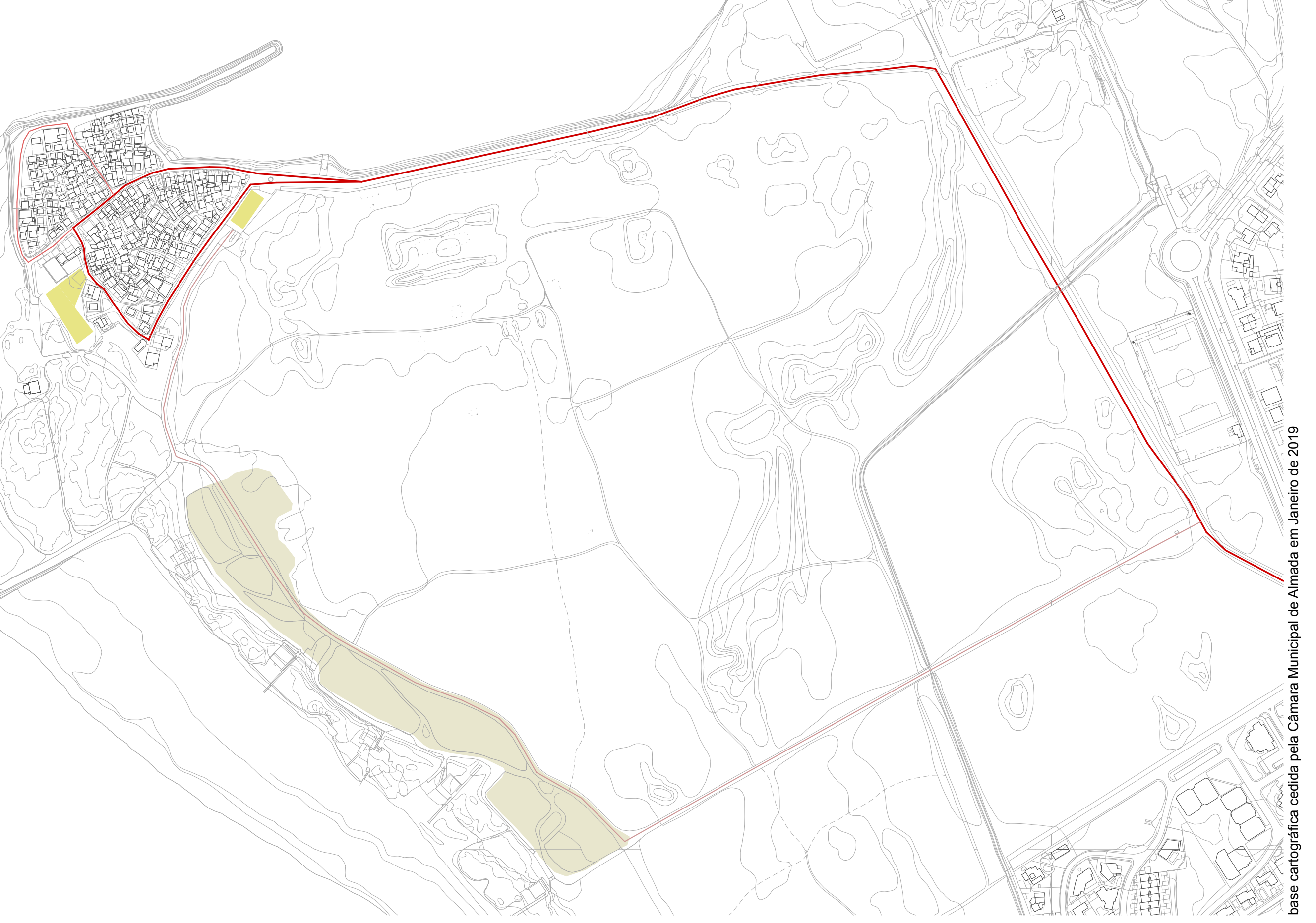




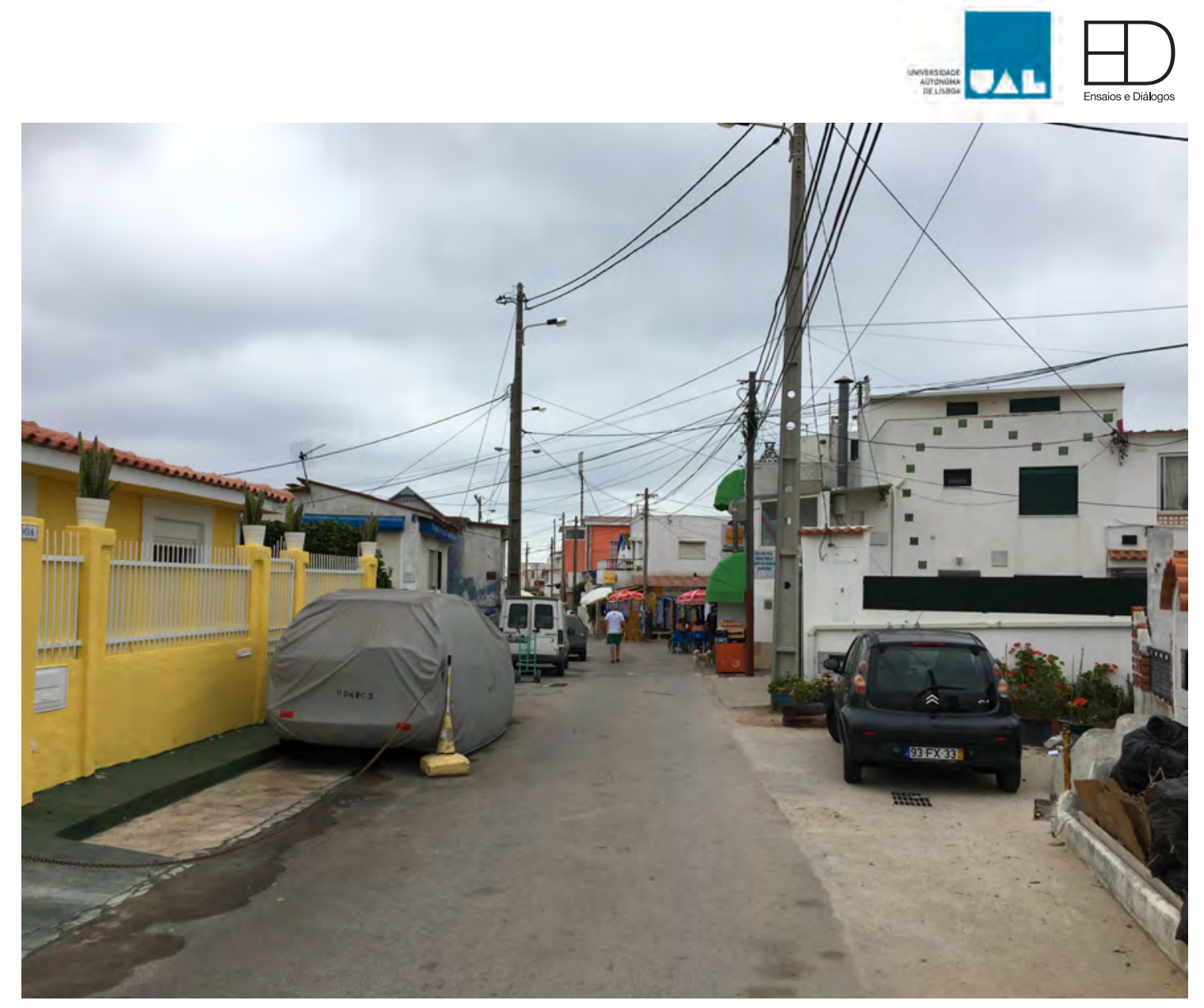

Figura 10 - Vista da Avenida António Martins Correia (julho, 2019).

Do cruzamento entre as duas avenidas, desenvolve-se a Rua Manuel Furtado Leite, a partir da qual se acede ao estacionamento junto às praias e à Rua do Parque que, a sul, delimita a malha urbana. Seguindo por essa via, regressamos à entrada do aglomerado urbano da Cova do Vapor.

Existe um segundo acesso viário, embora privado, a partir do recinto afeto às praias de São João da Caparica que, por se encontrar interrompido por portão, não é utilizado pelo trânsito automóvel.

O estacionamento automóvel no interior da Cova do Vapor, regra geral, é informal e ocupa parte da via.

Nos limites do aglomerado urbano existem duas zonas de estacionamento consolidadas. Uma junto à entrada da localidade e outra junto às praias. Durante a época balnear, estas duas áreas de estacionamento são ocupadas de forma pouco organizada e revelam-se insuficientes para suprir a pressão causada pelos visitantes.

Nas imediações da Cova do Vapor existe ainda a possibilidade de utilizar o estacionamento pago que serve as praias de São João da Caparica. 

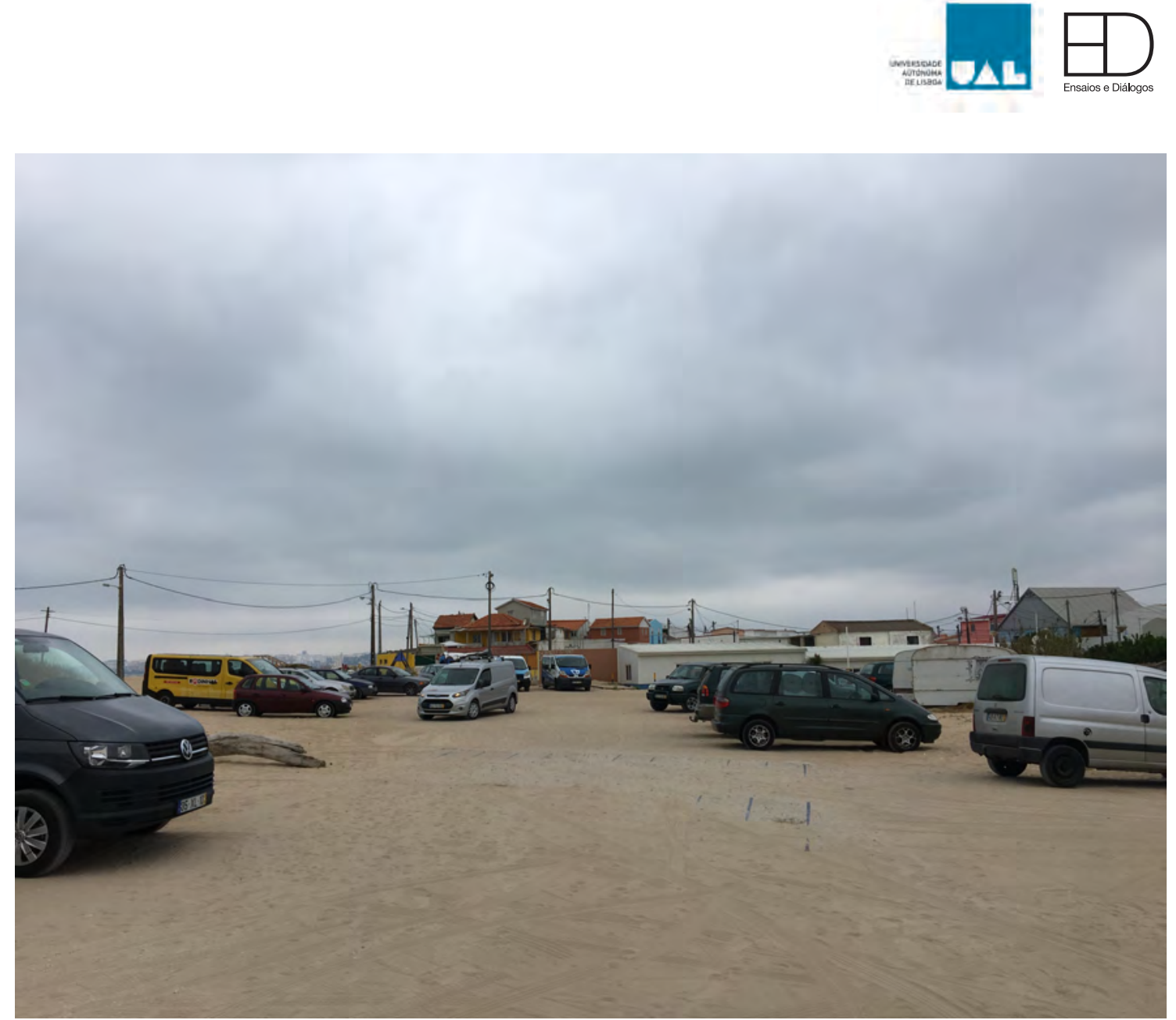

Figura 11 - Vista da área de estacionamento junto à praia (julho, 2019).

A mobilidade no interior da Cova do Vapor é definida pela permanente partilha da via entre o peão e o automóvel (Mapa 6). O estacionamento informal dentro do aglomerado urbano, mais intenso durante a época balnear, contribui de forma significativa para as dificuldades de mobilidade identificadas, pondo em causa, inclusive, a circulação e acesso de viaturas de emergência e socorro ao interior da localidade e às praias.

A via principal e secundária - Avenida António Martins Correia e Rua Jorge Loureiro que estruturam e dividem o aglomerado urbano são as mais exíguas e condicionadas.

Apesar de sujeitas às mesmas circunstâncias, identificaram-se algumas possibilidades de organização e hierarquização suave nas vias que definem os limites do aglomerado urbano - Avenida João Dias Mourinha, Rua Manuel Furtado Leite e Rua do Parque.

O acesso à praia é, na maioria dos casos, determinado pelo local de estacionamento do automóvel privado (Mapa 7).

Existem dois acessos, através de duas escadas, a partir do aglomerado urbano à designada Primeira Praia. Ambos os acessos são utilizados por moradores e por visitantes. A escada mais a norte, construída em estrutura de cimento sobre o 


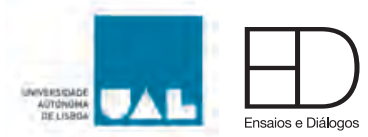

enrocamento, é uma estrutura com alguns anos, que foi recentemente melhorada com a instalação de corrimão metálico.

Durante o inverno de 2017/2018, a entrada para a praia foi tapada com madeiras, para evitar a afluência de sedimentos vindos do mar, obstruindo parcialmente o acesso pela rua principal. Em junho de 2018, no âmbito do laboratório in situ/, foi construída uma escada, em estrutura de madeira, de modo a permitir o acesso sem o pisoteio. 


\section{MAPA 6 - MOBILIDADE E ACESSIBILIDADE}

\section{ESC. $1 / 2000$}

Acesso pedonal público partilhado com via e estacionamento informal

Acesso pedonal público partilhado com via e estacionamento informal com capacidade de hierarquizaça

Acesso pedonal público com via parcialmente ocupada

Acesso pedonal privado partilhado com via e estacionamento informa

Acesso pedonal privado partilhado com via e estacionamento formal

Acesso pedonal através de vedação

Bolsas de estacionamento existente (formal e informal)

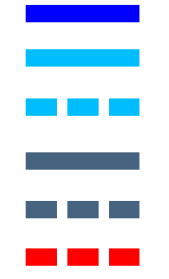

$\operatorname{ma}$

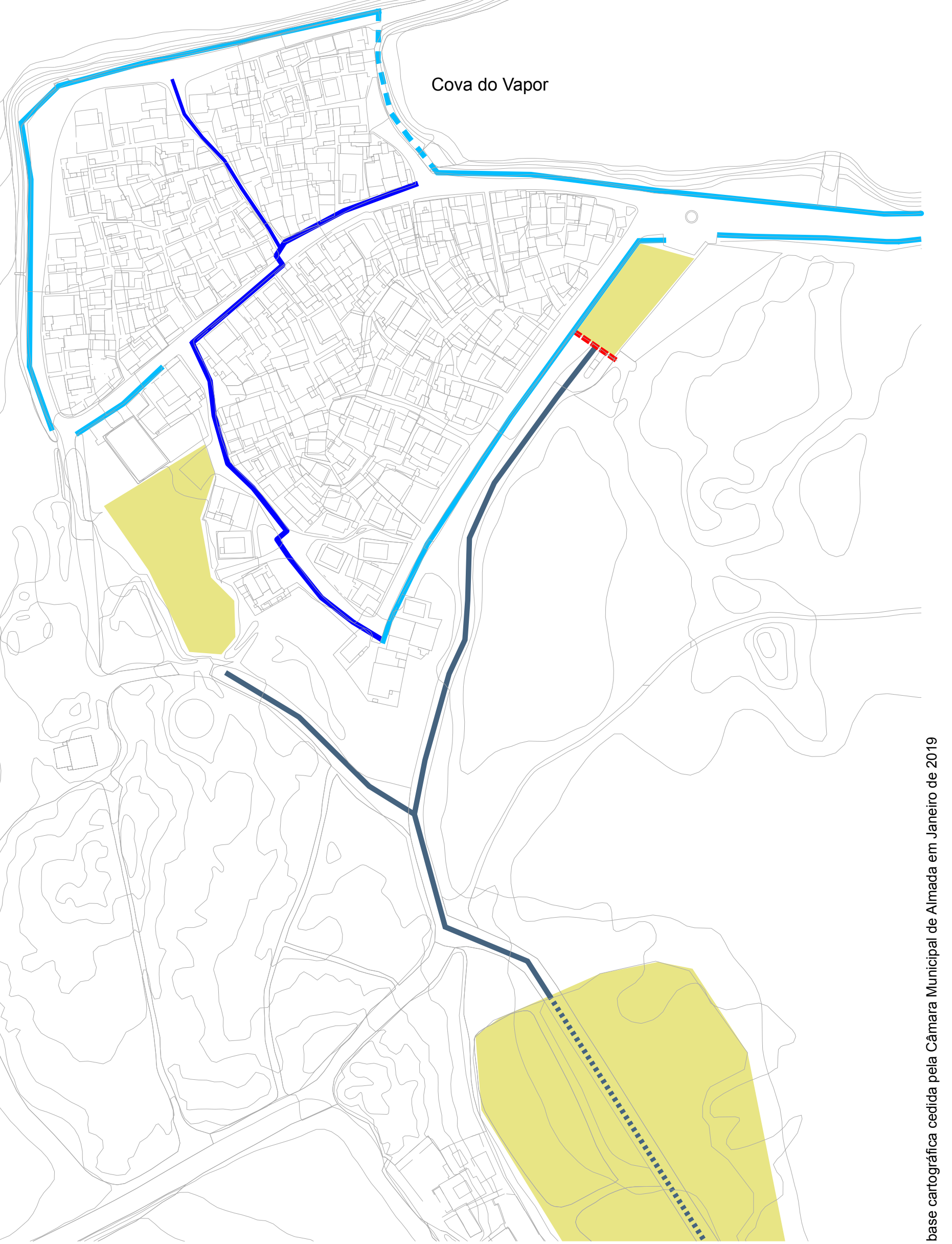


MAPA 7 - ACESSO À PRAIA

ESC. 1/2000

Escada

Passadiço

$+$

Informal

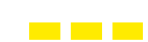

Praia da Cova do Vapor

Primeira Praia
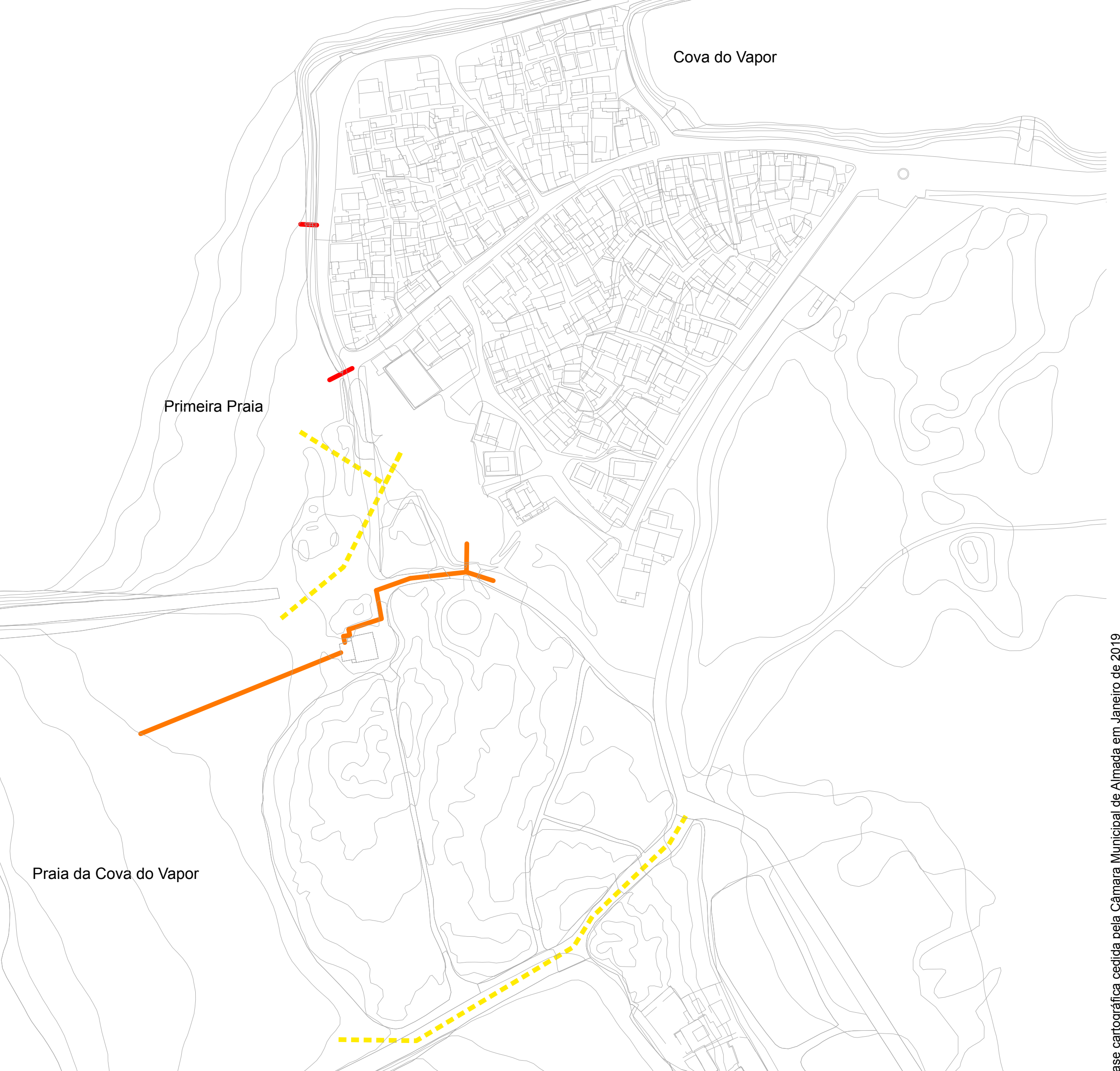

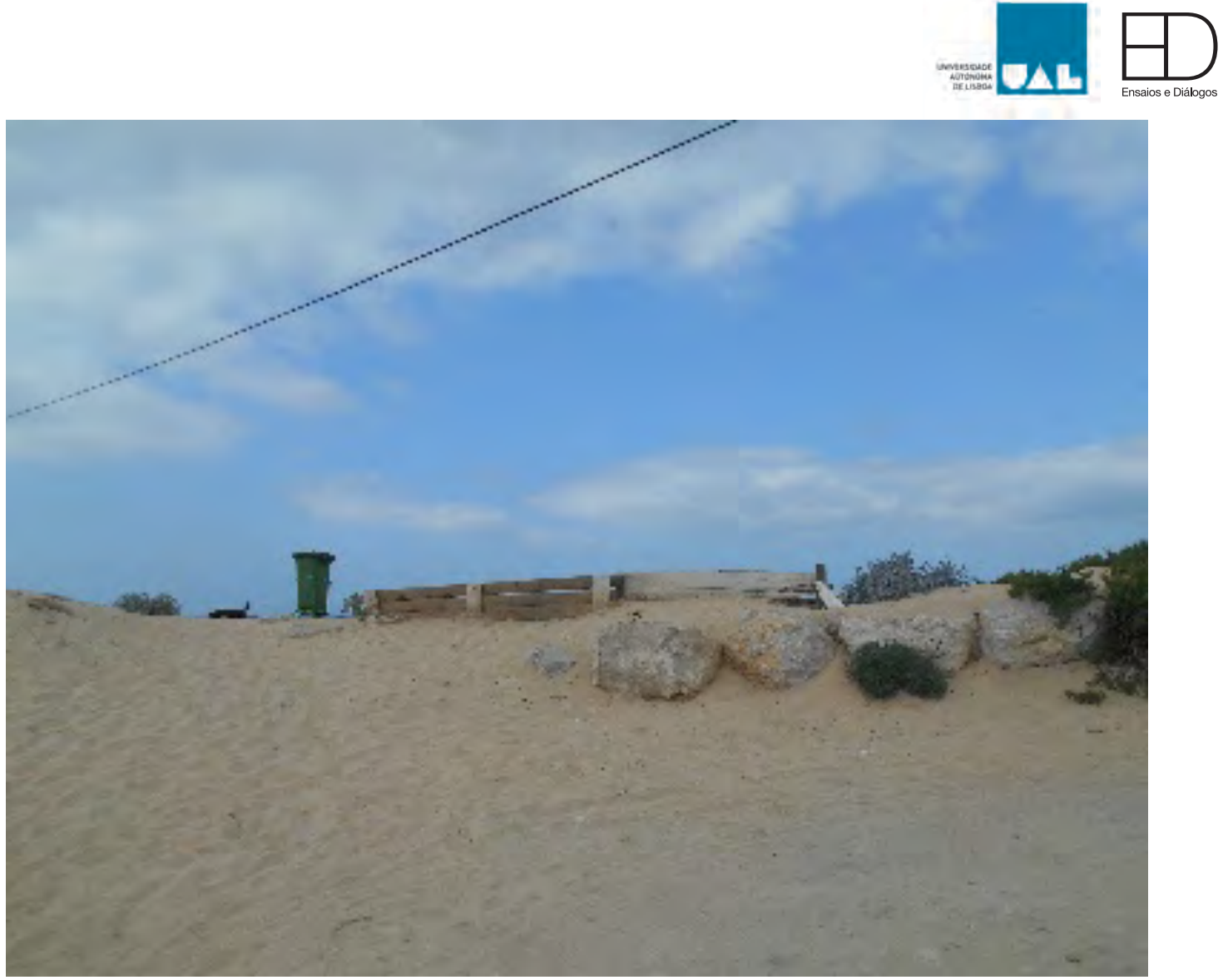

Figura 12 - Acesso à praia - local de intervenção do in situ/(junho, 2018).

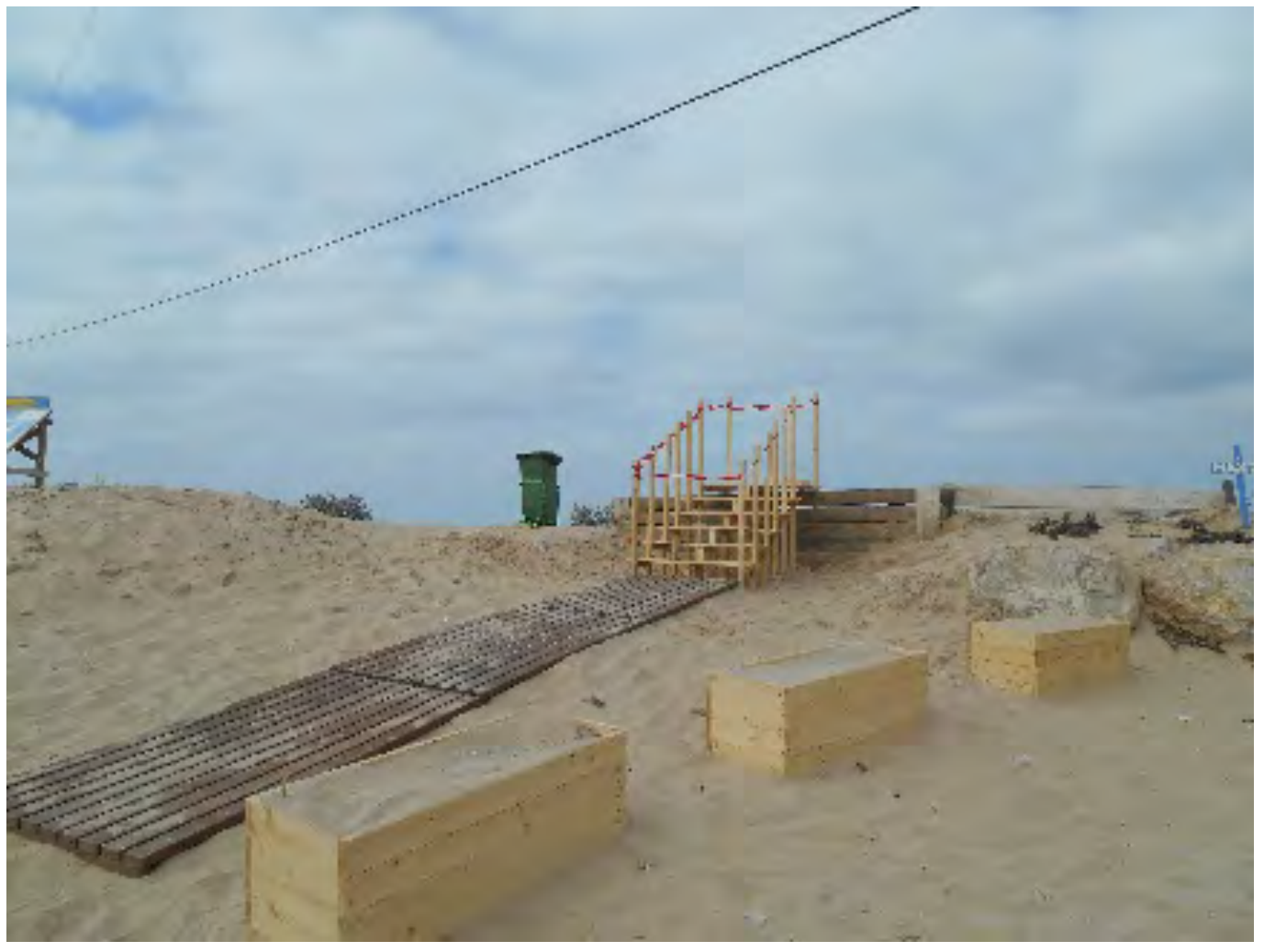

Figura 13 - Acesso à praia após a intervenção do in situ/(julho, 2018).

Cofinanciado por: 


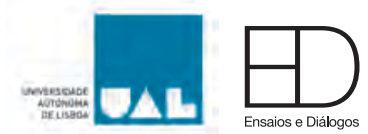

A partir da zona de estacionamento junto às praias podem ser feitos dois percursos de acesso ao areal. O primeiro, sobre a duna em formação, sendo o percurso mais curto para quem pretende aceder ao pontão que se estende no eixo visual do Farol do Bugio, serve as duas praias. Neste percurso, ainda visível no alinhamento dos postes de eletricidade, existiu até há cerca de dez anos um caminho, ladeado por pedras, onde havia inclusive circulação automóvel.

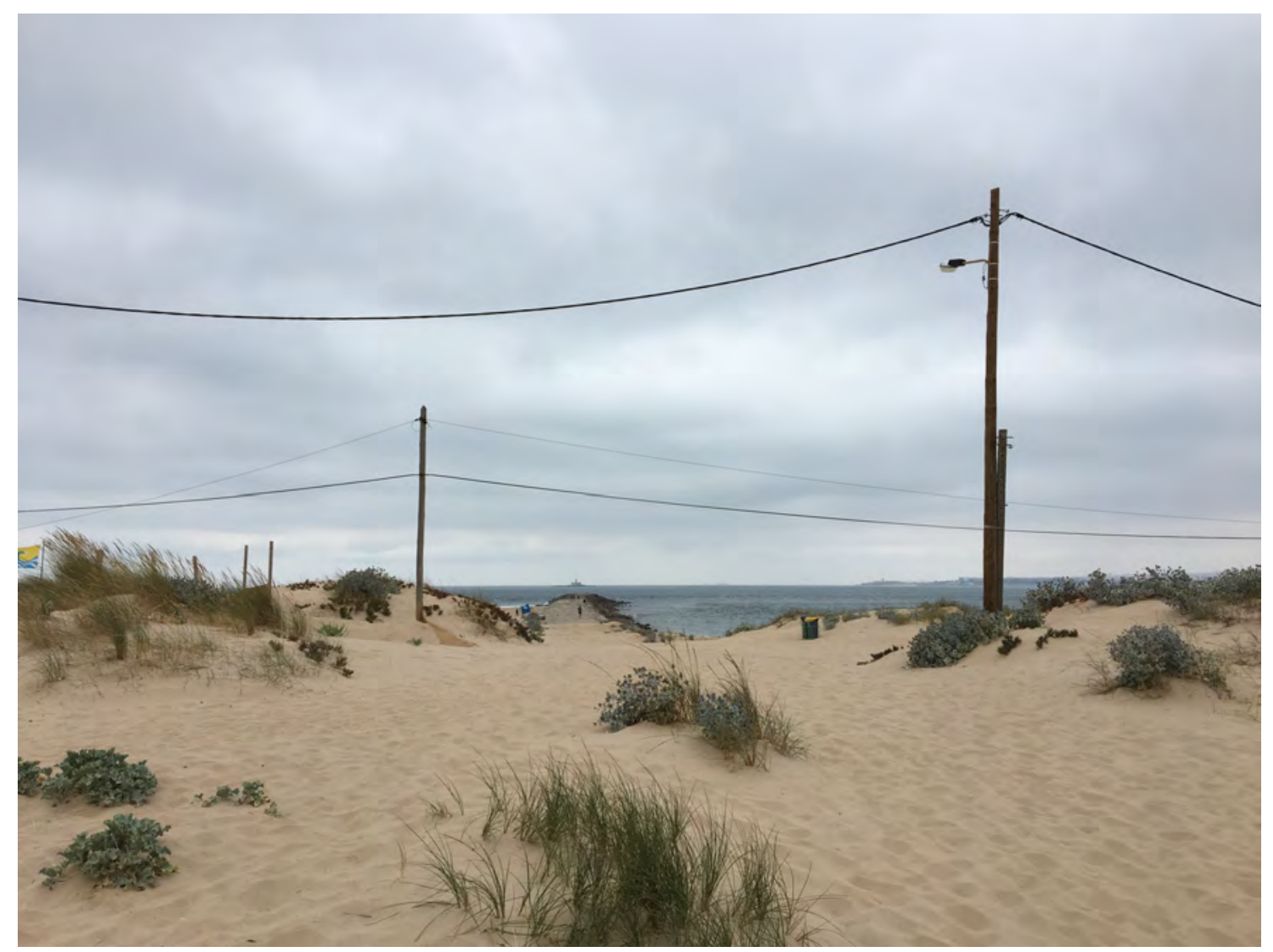

Figura 14 - Vista do pontão e Farol do Bugio (julho, 2019).

O segundo, sob passadiço de madeira, permite, através do apoio de praia existente, o acesso à praia da Cova do Vapor. Este passadiço pode ainda ser utilizado por quem chegue através do parque de estacionamento da Praia de São João da Caparica ou por alguém que, tendo estacionado o automóvel à entrada do aglomerado urbano da Cova do Vapor, faça o percurso a pé, através do caminho existente dentro da propriedade privada.

Mais a sul, um quinto acesso informal através do pontão que divide a Praia da Cova do Vapor da Praia de São João da Caparica, é também utilizado pelos tratores que fazem a limpeza da praia. 


\subsection{Estudos e projetos sobre a Cova do Vapor}

\subsubsection{Estudos realizados sobre a Cova do Vapor}

A Cova do Vapor tem sido objeto de diversos estudos nas últimas décadas, quer como parte do território de Almada onde se insere, quer como alvo direto. Foi já referido o Estudo de Enquadramento Estratégico Costa da Trafaria (2004), que teve um objetivo muito específico, dado que foi promovido por um consórcio público-privado, tendo como propósito uma ocupação urbanística que não se concretizou. A equipa que desenvolveu as várias componentes do estudo realizou uma vasta análise, essencialmente académica, e compilou, embora de forma algo setorial, informação que se encontrava dispersa. O estudo realizou ainda a recolha de dados junto da população, compreendendo sessões de participação nos vários aglomerados urbanos, incluindo a Cova do Vapor, para o diagnóstico dos problemas e sensibilidade para a sua solução.

Os estudos de índole académica possuem, necessariamente, uma natureza diferente, dado que têm como objetivo a investigação e a produção de novo conhecimento. A análise permitiu observar que se destacam, sobretudo duas temáticas: áreas costeiras e produção de espaços urbanos informais. Na primeira, a mais abundante em referências, inserem-se estudos de levantamento e pesquisa sobre aspetos da geologia, dinâmicas oceânicas, intervenções na costa, e análise a avaliação de risco (ex. Abreu, 2010; Veloso-Gomes et al; Veloso-Gomes; Taveira-Pinto, 2003; Veloso-Gomes et al, 200 e 2007; Pinto Taborda, Andrade, 2007; Silva, 2013; Kahn et al, 2013; Lira et al, 2016; Oliveira, 2015; Gomes, 2018; Gutierres et al, 2018). Na segunda, estudos sobre arquitetura informal e sobre as intervenções realizadas na Cova do Vapor, por vários autores e coletivos, com o apoio de associações, grupos locais, moradores e voluntários nacionais e internacionais (Mateus, 2010; Ferreira, 2014; Ribeiro, 2015; Braga, 2015). Na realidade, estes projetos suscitaram interesse por parte da comunidade académica, que os estuda no âmbito da discussão, muito desenvolvida nas últimas décadas, sobre intervenções em territórios de precariedade, ou até mesmo de exclusão. Estas abordagens analisam territórios onde imperam redes informais, que constroem dinâmicas capazes de dar resposta a problemas que o ordenamento formal não consegue resolver. Para tal, contribui a escolaridade cada vez maior das populações envolvidas nos projetos (residentes ou não nos locais) e a partilha de experiências e o trabalho em rede proporcionados pelas ferramentas digitais e pelas novas tecnologias de comunicação.

Por último, regista-se uma comunicação numa conferência (Vasconcelos, 2015), que apresenta uma preocupação um pouco à margem das anteriores, focada no tema dos conflitos ambientais decorrentes de usos com algum grau de incompatibilidade (neste caso, pesca artesanal e turismo). 


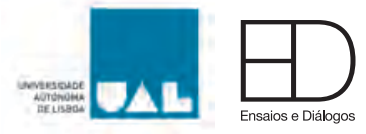

\subsubsection{Projetos com a comunidade local para a proteção do litoral}

O trabalho sistemático de sensibilização ambiental na Cova do Vapor iniciou-se em 2017, pela mão da Associação Ensaios e Diálogos (EDA). Desde a conceção do primeiro projeto, Casa do Vapor, que se identificou claramente a vulnerabilidade ambiental a que esta comunidade está exposta e a ecologia humana tornou-se numa das áreas de intervenção, sensibilização e capacitação. A par de ações de sensibilização ambiental, que introduziram noções de botânica endémica, informação básica sobre comportamentos geomorfológicos e sedimentação das areias da praia, a instalação da Casa do Vapor respeitou técnicas de construção antigas e adaptadas ao meio ambiente, criou uma fossa ecológica para tratamento de águas residuais, e desenvolveu um programa educativo, tendo por base o património cultural e ambiental, que inclui desde atividades sobre barcos da arte Xávega à criação de astrolábios e observação de estrelas.

Após a conclusão do projeto Casa do Vapor, a EDA instalou a Biblioteca do Vapor (BV), com o apoio da Associação de Moradores da Cova do Vapor. Esta é uma biblioteca comunitária permanente, que dá continuidade ao trabalho realizado, promovendo o desenvolvimento cultural e comunitário. A BV tornou-se num espaço de encontro e partilha entre moradores e visitantes e desenvolve atividades que extravasam a área do livro e leitura. Em 2015, a EDA transitou a gestão da BV para um Conselho Gestor Comunitário, e, em 2016, este conselho sentiu a necessidade de se tornar numa associação, criando a Associação Margem de Coragem. É na Biblioteca do Vapor que, desde 2017, se tem estruturado e implementado um programa de sensibilização ambiental e procurado financiamento para a concretização das necessidades identificadas.

Em 2014, as praias de São João da Caparica, contíguas à Cova do Vapor, foram fortemente atingidas pela tempestade Hércules, causando uma forte erosão e recuo de linha de costa. No ano seguinte, a CMA e o Departamento de Ambiente implementaram o projeto REDUNA, um projeto de proteção costeira de regeneração dunar. Os resultados visivelmente positivos foram muito discutidos entre os moradores da Cova do Vapor e, desde cedo, foi manifesto o interesse na replicação e aplicação deste projeto na Primeira Praia e Praia da Cova do Vapor.

Em 2017, em resultado de uma parceria entre a Associação Margem de Coragem, a Associação Ensaios e Diálogos e a Associação de Moradores da Cova do Vapor, foi criado o TransforMar, um projeto de desenvolvimento local, cuja conceção partiu da identificação das vontades e necessidades dos moradores. É um projeto que se pretende de continuidade e que visa a valorização do património cultural, natural, e paisagístico da Cova do Vapor.

A partir do mapeamento e auscultação pública de 2017 e 2018, identificou-se a necessidade de reagir face à situação degradada do ecossistema dunar localizado entre a fronteira urbana e as praias da Cova do Vapor. Graças a várias ações de sensibilização ambiental, promovidas nos programas culturais de 2017 e 2018, o tema da proteção dunar e do litoral foi abordado de várias formas: ações de apanha de lixo 


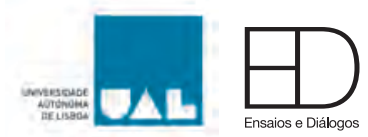

nas praias, plantio de Ammophila arenaria (estorno), iniciativas de angariação de fundos, visitas guiadas, entre outras. Graças ao estabelecimento de parcerias e à colaboração com entidades públicas e privadas, a Biblioteca do Vapor reforçou a sua rede de trabalho, no sentido de promover o desenvolvimento local e a sustentabilidade desta comunidade, cada vez mais consciente e sensível a questões do meio ambiente e ecologia (mais informação sobre iniciativas de sensibilização TransforMar em anexo).

Por acreditar na implementação de estratégias de mudança social de base comunitária, em 2018, a EDA decidiu apostar na sensibilização dos moradores e utentes da praia da Cova do Vapor para a importância de preservar dos seus recursos naturais, em particular o ecossistema dunar que se estende frente ao parque de estacionamento.

Embora atualmente desvinculada da gestão interna da Biblioteca do Vapor, a EDA mantém desde sempre, a participação no que diz respeito ao desenvolvimento e apoio às atividades desta e à Associação Margem de Coragem, gestora do projeto TransforMar. Foi no sentido de fortalecer as iniciativas pensadas para o TransforMar em 2017 e 2018 que a EDA idealizou o TransforMart, dando continuidade ao TransforMar, na sua missão de promover o desenvolvimento local sustentável através do estímulo às atividades culturais e de sensibilização ambiental. O projeto TransforMar+ consiste na elaboração do presente estudo e na realização de um filme de sensibilização ambiental sobre e para a Cova do Vapor.

O estudo (como já foi referido) visa a identificação de possibilidades de atuação para a boa preservação e promoção dos recursos culturais, naturais e paisagísticos da zona das dunas, junto ao aglomerado urbano na Cova do Vapor. O material resultante deste pretende servir como referência futura no desenho de um plano integrado de preservação do sistema dunar da Cova do Vapor.

O filme documental, feito a partir do depoimento de moradores e utentes da Cova do Vapor, visa a valorização do seu património cultural, humano, natural e paisagístico, estimulando assim o desenvolvimento local, o sentimento de pertença e a responsabilização ambiental de quem vive na Cova do Vapor. 


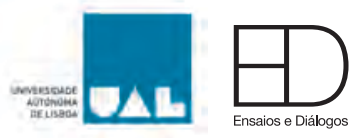

\section{Apresentação e análise de dados do trabalho de campo}

A recolha de informação para a realização deste estudo teve uma componente fundamental de trabalho de campo. Este teve início em 2018, para a preparação e realização do Laboratório de Intervenção em Arquitetura in situ/ e foi composta por pesquisa bibliográfica, observação e levantamento fotográfico e cartográfico. Para a presente análise, para além do aprofundamento da pesquisa bibliográfica, foram também realizadas outras ações no terreno: realização de inquéritos e dinamização de uma sessão de discussão com a população.

\subsection{Inquéritos aos utilizadores da praia}

Um dos principais fatores causadores da degradação das dunas é a pressão antrópica decorrente do pisoteio, para uso balnear ou recreativo da praia. Como todas as praias do Eixo Cova do Vapor - Cabo Espichel, as praias da Cova do Vapor têm uma procura considerável por "banhistas" durante a época balnear. Durante todo o ano, há também alguma procura por parte de praticantes de surf e de pescadores, estes dirigindo-se sobretudo aos pontões, para pesca à linha. Esta utilização, que pode chegar a ser muito intensiva nos dias de verão, acresce à daqueles que possuem casa na Cova do Vapor.

Na última década, após o ordenamento do estacionamento na praia vizinha de São João, este passou a ser pago, o que parece ter aumentado a pressão na Cova do Vapor e imediações, onde - de forma bastante desordenada - se estaciona gratuitamente.

Por esta razão, considerou-se fundamental realizar um inquérito aos utilizadores da praia (em anexo), não residentes (embora contemplando a hipótese de estarem temporariamente alojados na Cova do Vapor). Este inquérito teve dois objetivos: 1) conhecer o perfil de utilizadores da Cova do Vapor e o seu padrão de utilização da praia; 2) avaliar o seu grau de conhecimento sobre as dunas, o seu estado e disponibilidade para colaborar em possíveis medidas de recuperação.

Foram realizados 100 inquéritos, em três dias distintos (26 de junho, 9 de julho e 17 de julho de 2019), 70 na Praia da Cova do Vapor e 30 na Primeira Praia. Este número foi definido após contagem, procurando manter, aproximadamente, a proporção entre $o$ número de pessoas presentes em cada praia. Optou-se, sempre que os inquiridos estavam em grupo, por realizar apenas um inquérito por grupo.

Nos inquéritos realizados durante os dias de semana, durante a manhã, registou-se a presença de um número elevado de crianças (cerca de 250) na Praia da Cova do Vapor, que ali se deslocavam em programas de "ida à praia" organizados, acompanhados por educadoras e monitoras. Estas crianças deslocam-se até à Cova do Vapor em autocarros, que ficam estacionados no espaço de parqueamento à entrada da Cova do Vapor, fazendo depois o percurso até à praia a pé, atravessando a duna junto ao restaurante Albatroz para entrar na praia. Embora se tenham observado outros grupos escolares, este era o de maior dimensão. Por esta razão, foram feitos 3 inquéritos a este grupo, 2 a crianças (com o auxílio do inquiridor e da educadora) e 1 a uma das educadoras. 


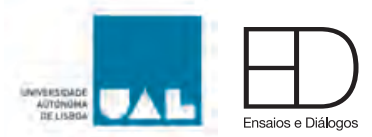

Dos inquiridos, 53 são mulheres e 47 homens. A média etária é de 39,4, com a seguinte distribuição: até 20 anos - 5 inquiridos; 21 a 35 anos -42 inquiridos; 36 a 50 anos - 35 inquiridos; 51 a 75 anos -16 inquiridos; mais de 75 anos -2 inquiridos.

Quanto ao concelho de residência, predominam os concelhos de Lisboa (34) e Almada (28). Os restantes inquiridos distribuem-se pela área metropolitana de Lisboa (Alcochete - 1; Amadora - 10; Cascais - 1; Loures - 2; Odivelas - 4; Oeiras - 1; Seixal 6; Setúbal - 1; Sintra - 3; Vila Franca de Xira - 3), havendo um número mais reduzido de outras proveniências em Portugal (Porto - 2, Arruda dos Vinhos, Chamusca e Leiria -1) e um inquirido residente em França.

Quanto às habilitações, a distribuição é a seguinte: 10 ciclo - 4 inquiridos (2 estudantes), 2ㅇc이 - 2 inquiridos; 3 ciclo - 15 inquiridos; secundário ou equivalente: 39 inquiridos; ensino superior -40 inquiridos.

A atividade profissional dos inquiridos centra-se, como é caraterístico das áreas metropolitanas, no terceiro setor, o dos serviços (75), registando-se 3 inquiridos do setor secundário e nenhum do primário. Os restantes inquiridos são estudantes (8), reformados (5), desempregados (4) ou sem atividade económica (3). Dois inquiridos não responderam a esta questão. No que diz respeito às profissões existentes no setor terciário, há uma predominância por profissões relacionadas com formação universitária (24), registando-se ainda, dentro do setor terciário, 13 inquiridos com profissões na área administrativa e 11 ligados ao comércio e atendimento.

$\mathrm{Na}$ tabela seguinte, observamos os dados relativos à caraterização dos inquiridos. Uma vez que foram realizados 100 inquéritos, o número absoluto corresponde também à percentagem de respostas: 


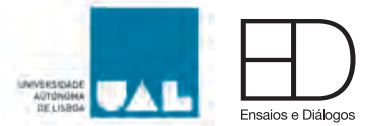

\begin{tabular}{|c|c|}
\hline Questão & Resposta (número respostas) \\
\hline $\begin{array}{l}\text { Quando veio pela primeira vez à praia à } \\
\text { Cova do Vapor? }\end{array}$ & $\begin{array}{l}\text { É a primeira vez (14) } \\
\text { Há um ano ou menos (19) } \\
\text { Entre dois a cinco anos (18) } \\
\text { Há mais de dez anos (19) } \\
\text { Desde sempre (30) }\end{array}$ \\
\hline $\begin{array}{l}\text { Tendo o último ano (incluindo verão de } \\
\text { 2018) como referência, quantas vezes veio } \\
\text { à praia à Cova do Vapor? }\end{array}$ & $\begin{array}{l}1(10) ; 2 \text { a } 5(19) ; \\
6 \text { a } 10(10) ;>10(43) \\
1 \text { a vez }(14)\end{array}$ \\
\hline Está alojado na Cova do Vapor? & $\begin{array}{l}\text { Não (88) } \\
\text { Sim, quarto ou casa alugado (8) } \\
\text { Sim, casa de familiares ou amigos (4) }\end{array}$ \\
\hline Como chegou à Cova do Vapor? & $\begin{array}{l}\text { Transporte próprio (carro) (85) } \\
\text { Transporte próprio (mota) (1) } \\
\text { Transporte próprio (bicicleta) (3) } \\
\text { Transporte coletivo (autocarro) (5) } \\
\text { A pé vindo do barco (0) } \\
\text { A pé vindo de outro local (1) } \\
\text { Outro (1) }\end{array}$ \\
\hline $\begin{array}{l}\text { Se veio em transporte próprio, onde } \\
\text { estacionou? }\end{array}$ & $\begin{array}{l}\text { No parque à entrada (33) } \\
\text { No parque junto à praia (27) } \\
\text { No interior do aglomerado (30) } \\
\text { Outro (1) }\end{array}$ \\
\hline Com quem veio? & $\begin{array}{l}\text { Sozinho (20); Com família (53) } \\
\text { Com amigos (22); Outro (5) }\end{array}$ \\
\hline Por onde acedeu à praia? & $\begin{array}{l}\text { Pela rua principal (64) } \\
\text { Pelo acesso junto ao Albatroz (13) } \\
\text { Atravessou a duna junto à biblioteca (11) } \\
\text { Pelo acesso de São João (10) }\end{array}$ \\
\hline Porque escolheu esta praia? & $\begin{array}{l}\text { Pela tranquilidade (73) } \\
\text { Pela paisagem (4) } \\
\text { Por ser diferente (1) } \\
\text { Estacionamento sem custos (6) } \\
\text { Por ter aqui família ou amigos (8) } \\
\text { Por tradição (8) } \\
\text { Por ser a mais acessível (3) } \\
\text { Para fazer surf (2) }\end{array}$ \\
\hline $\begin{array}{l}\text { Quanto tempo vai permanecer hoje na } \\
\text { praia? }\end{array}$ & $\begin{array}{l}<2 \mathrm{~h}(24) ; \text { Manhã ou tarde (54); } \\
\text { Todo o dia (22) }\end{array}$ \\
\hline Irá usufruir de outros espaços? & $\begin{array}{l}\text { Cafés / padaria (56); Outro comércio (29) } \\
\text { Biblioteca (1); Outros (3) }\end{array}$ \\
\hline Custo estimado do dia $(€)$ & $\begin{array}{l}<10(67) ; 11 \text { a } 20(14) ; 21 \text { a } 30(4) \\
>30(3)\end{array}$ \\
\hline
\end{tabular}

Tabela 4 - Perfil do utilizador da praia da cova do vapor (Fonte: inquéritos 2019). 


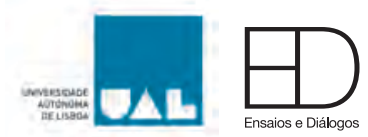

Em síntese, do total dos inquiridos, cerca de metade (49) é utente habitual desta praia há mais de dez anos, sendo que 30 pessoas declararam que "desde sempre" vão à Cova do Vapor. Compreende-se que há um padrão de fidelidade a este local, mas também uma capacidade de atração de novos utentes (14 declararam ser a primeira vez que ali iam). É também uma praia de uso habitual, dado que 43 pessoas declararam ter ido à Cova do Vapor mais do que dez vezes no último ano.

Os utentes da praia são maioritariamente não residentes. De facto, praticamente não foi possível encontrar residentes da Cova do Vapor, o que deixa algumas questões relativas aos padrões de utilização da praia pelos residentes (uma hipótese poderá ser a de que a proximidade da casa induza a períodos mais curtos de permanência). 12 dos inquiridos, não sendo residentes, estavam alojados na Cova do Vapor, em casas de amigos ou espaços alugados para férias, o que demonstra a existência de uma procura por estas soluções, assim como a vocação balnear sazonal desta área.

No que diz respeito aos meios de transporte utilizados para chegar à Cova do Vapor, a esmagadora maioria dos inquiridos utilizou o carro, tendo estacionado quer no interior quer no exterior do aglomerado urbano. $O$ acesso a pé à praia é feito maioritariamente pela rua principal utilizando a escada construída em 2018 durante o in situ/, havendo, contudo, 11 pessoas (e famílias, quando é o caso) que atravessaram a duna junto à biblioteca. 13 inquiridos utilizaram o acesso junto ao Albatroz. Talvez pelo facto de os inquiridos de deslocarem sobretudo de carro, este parece ser um destino de família (53), escolhido sobretudo pela tranquilidade (73) e para uma permanência de meio dia (54). O facto de se ter família ou amigos na Cova do Vapor, associado à tradição, ou hábito de frequentar esta praia, acaba por ter algum relevo na escolha desta praia como destino (18), mas não parece ser determinante.

Os inquiridos conheciam, na sua maior parte, o comércio existente e utilizam sobretudo os cafés e a padaria, mas mantendo os custos da ida à praia em valores relativamente baixos.

O seguinte grupo de questões diz respeito à perceção dos inquiridos sobre a situação de referência e ao seu potencial de mobilização para contribuir para mudanças de comportamento.

À questão "Tem conhecimento de que a Cova do Vapor se encontra numa zona de risco?", 47 pessoas responderam afirmativamente. Mas apenas 12 identificaram riscos, tendo sido estes: sísmico (2), erosão e avanço do mar (2), incêndio urbano, lixo, correntes marítimas, cheias/galgar das águas/tempestades, arriba fóssil, casas em risco e risco ambiental/dunas (1). No entanto, à pergunta "Considera que é importante proteger as dunas da Cova do Vapor?", foram 99 as respostas "sim" e 1 "talvez". Desta forma, registou-se um nível baixo de conhecimento concreto desta questão, mas uma perceção de consenso em relação à proteção dunar em abstrato.

Foi ainda perguntado "Na sua opinião, qual o estado de conservação das dunas da Cova do Vapor?". A resposta a esta questão distribuiu-se da seguinte forma: muito destruído (19); razoável (42); bom (24); não sabe / não responde (15). Vale a pena diferenciar aqui os inquéritos realizados na Primeira Praia e na Praia da Cova do Vapor. 


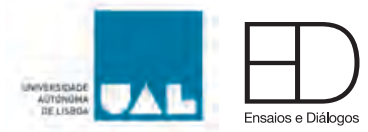

Assim, dos 30 inquéritos realizados na Primeira Praia, 12 inquiridos consideraram que o estado de conservação das dunas era muito destruído, 10 razoável e 4 bom. Dos 70 inquiridos na Praia da Cova do Vapor, 7 consideraram o estado de conservação muito destruído, 32 razoável e 20 bom. Esta análise indica uma diferença clara de perceção em relação à situação de cada uma das praias.

Aos inquiridos foi pedido que classificassem (de 1, mínimo, a 5, máximo) diversos aspetos da praia. A soma de todas as respostas encontra-se no gráfico seguinte, diferenciada por praia. Dado que foram feitos 30 inquéritos na Primeira Praia e 70 na Praia da Cova do Vapor, o valor máximo possível (ou seja, se todos os inquiridos tivessem atribuído o valor 5) para a Primeira Praia seria de 150 e para a Praia da Cova do Vapor de 350. Os resultados permitem observar que a qualidade da água é o aspeto melhor pontuado, em ambas as praias, sendo a limpeza considerada também maioritariamente muito boa na Praia da Cova do Vapor. Os aspetos pior pontuados foram, na Primeira Praia, a vigilância e apoio de praia (inexistentes) e o estacionamento, na Praia da Cova do Vapor. Para os utentes da Primeira Praia, quer o acesso à Cova do Vapor quer o acesso à praia foram bem classificados.

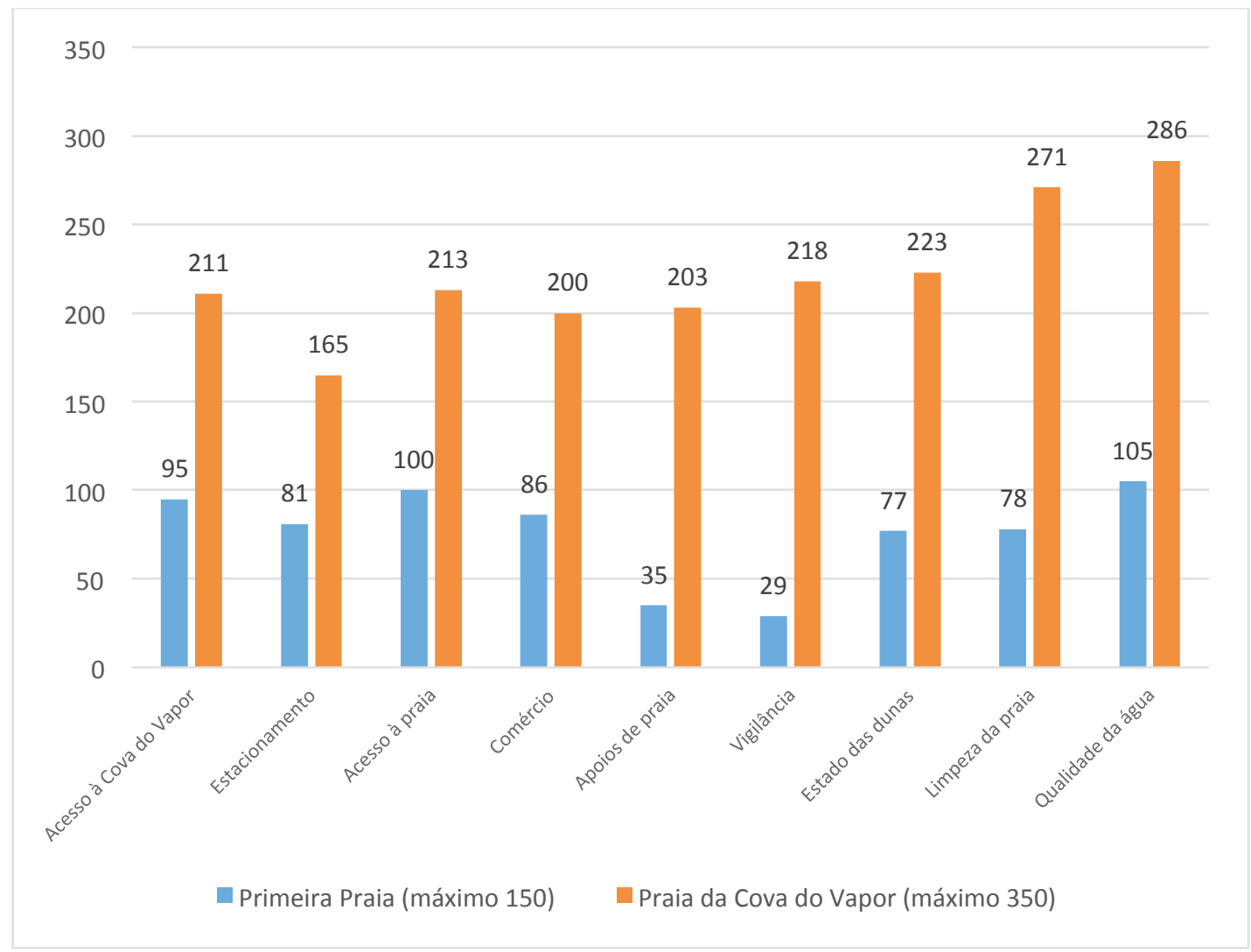

Figura 15 - Soma das avaliações (1 a 5) da Primeira Praia e Praia da Cova do Vapor, por categoria e por praia (Fonte: inquéritos 2019). 


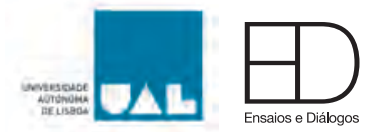

A frequência de respostas (moda) confirma estes dados, na medida em que na Praia da Cova do Vapor predomina o valor 3 em todas as opções, exceto para a vigilância e limpeza da praia (4) e qualidade da água (5). Já para a Primeira Praia há uma maior flutuação, sendo o valor predominante o 3 apenas no acesso à Cova do Vapor, acesso à praia, comércio e limpeza da água, distribuindo-se depois da seguinte forma: apoios de praia (predomina a ausência de resposta), vigilância (1), estado das dunas (2) e estacionamento e qualidade da água (4).

Procurando avaliar a predisposição dos inquiridos para mudar os seus hábitos e para participar ativamente em processos de mudança, foi perguntado se estariam dispostos (de 1, nada disposto, a 5, totalmente disposto) a realizar algumas ações. A soma das respostas, seguindo o mesmo critério do gráfico anterior, encontra-se sistematizada na figura seguinte.

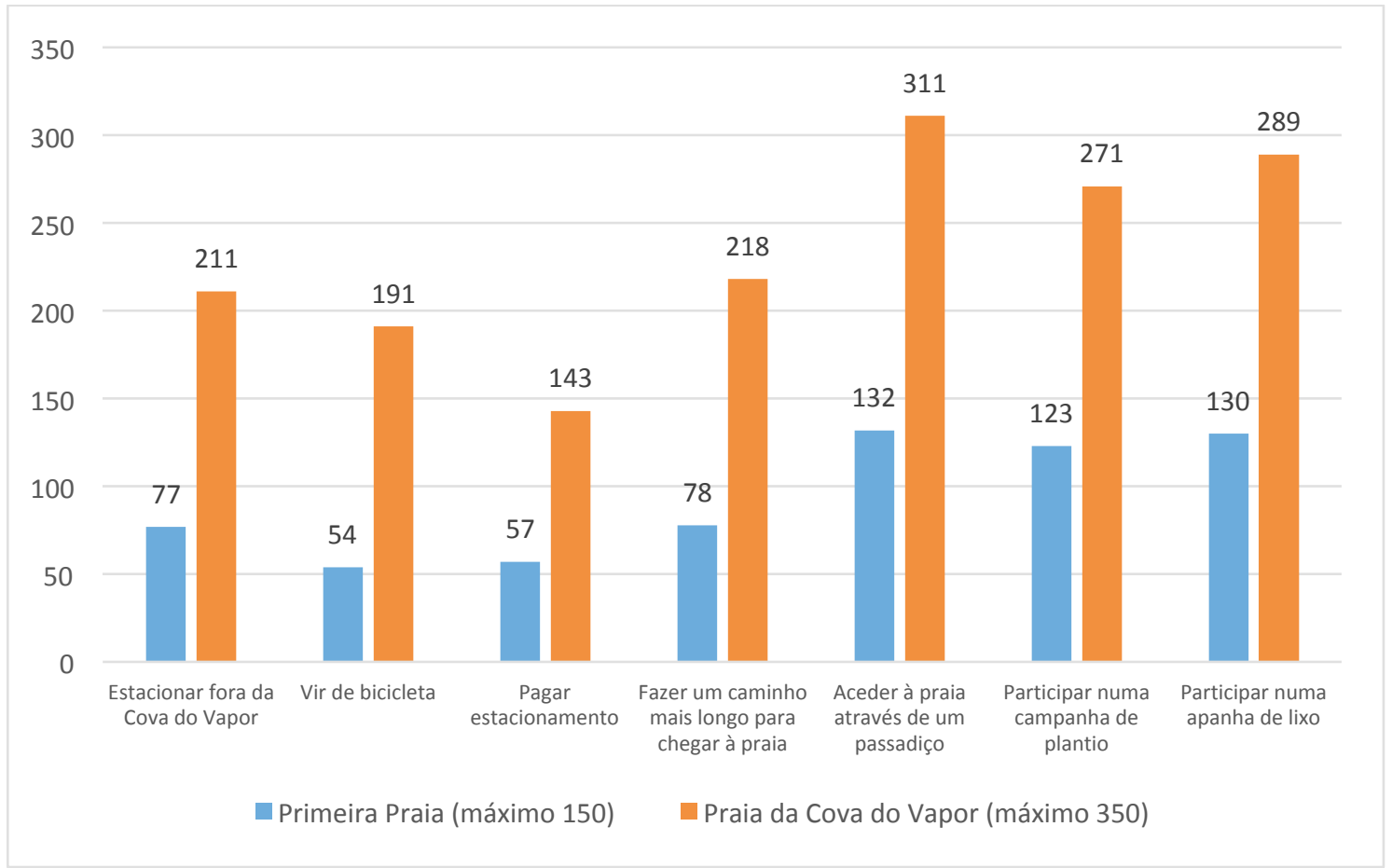

Figura 16 - Soma da predisposição para novos hábitos (1 a 5) na Primeira Praia e Praia da Cova do Vapor, por categoria e por praia (Fonte: inquéritos 2019).

A moda das respostas é, na Primeira Praia, de 1 para as primeiras quatro opções, e de 5 para as três últimas. Desenvolvendo um pouco, dos 30 inquiridos nesta praia, escolheram o valor 1 em relação a estacionar fora da Cova do Vapor, vir de bicicleta, pagar estacionamento e fazer um caminho mais longo, respetivamente, 13, 21, 17 e 12 inquiridos. E escolheram o valor 5 em relação ao uso de um passadiço, participar numa campanha de plantio ou numa apanha de lixo, respetivamente, 17, 15 e 20 inquiridos.

Já na Praia da Cova do Vapor, a segunda, a terceira e as três últimas opções obtiveram um resultado semelhante ao da Primeira Praia, mas, no caso da primeira opção (estacionar fora da Cova do Vapor), a resposta mais frequente (embora com apenas uma resposta de diferença em relação à opção 5) foi a oposta, já que a moda foi 5. 


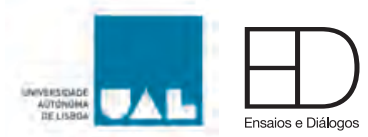

Na opção pela disposição de fazer um caminho mais longo a moda foi 3 para esta praia. Assim, dos 70 inquiridos na Praia da Cova do Vapor, escolheram o valor $1 \mathrm{em}$ relação a vir de bicicleta e a pagar estacionamento, respetivamente, 29 e 37 pessoas. Escolheram o valor 5 em relação ao uso de um passadiço, participar numa campanha de plantio ou numa apanha de lixo, respetivamente, 46, 27 e 41 inquiridos. Escolheram o valor 5 em relação a estacionar fora da Cova do Vapor 20 inquiridos. Por fim, na opção pela disposição de fazer um caminho mais longo, 21 pessoas escolheram o valor 3.

Estes resultados são particularmente interessantes, por confirmarem as pressões causadas pelo uso balnear, em temos de tráfego e estacionamento, assim como a fraca apetência para optar por estas praias caso o estacionamento fosse pago (embora alguns inquiridos tivessem mostrado disponibilidade para pagar, se o valor cobrado fosse simbólico e revertesse para associações locais), mas também por mostrarem diferenças de atuação nas duas praias. A fraca adesão à mobilidade ciclável parece justificar-se pelo facto de a maior parte dos inquiridos de deslocar com a família, alguns com crianças, trazendo equipamento para a praia (chapéu de sol, brinquedos, sacos de praia). É consensual a importância e o potencial de utilização de um futuro passadiço. Um aspeto curioso é que os inquiridos se mostraram mais disponíveis para participar em apanhas de lixo do que em ações de plantio para a proteção das dunas, o que reflete graus de sensibilização diferentes para cada uma das questões.

Foi ainda perguntado se os inquiridos conheciam o projeto REDUNA. Dos inquiridos, 17 responderam afirmativamente. Desses, apenas 2 souberam explicar em que consistiu o projeto.

Por fim, o inquérito incluía quatro perguntas de resposta aberta: 1) Que medidas podem ser tomadas para proteger as dunas? 2) O que tem de pior a Cova do Vapor? 3) E de melhor? 4) O que faz mais falta?

Embora fossem, essencialmente, perguntas destinadas a compreender melhor o contexto das respostas dadas, com um intuito geral de sensibilização, a análise qualitativa das repostas permite tecer, brevemente, algumas considerações. $\mathrm{Na}$ questão 1 (Que medidas podem ser tomadas para proteger as dunas?), 35 inquiridos declararam não saber que medidas se poderiam tomar. Os restantes referiram sobretudo medidas como plantio, passadiços, proteger com vedações, revelando estar familiarizados com soluções deste género. Na pergunta 2 ( $O$ que tem de pior a Cova do Vapor?), as respostas centram-se sobretudo nos acessos, estacionamento e limpeza da praia e nas condições da praia no momento (vento), tendo 18 inquiridos respondido "nada". Quanto à pergunta 3 (O que tem de melhor a Cova do Vapor?) destaca-se a tranquilidade (34 menções) e sossego, as caraterísticas da praia (areal, água). Na última questão (O que faz mais falta?), 17 pessoas responderam "nada", havendo sobretudo menção à falta de WC, de chuveiros, de estacionamento e de vigilância (neste último caso das 9 respostas, 7 delas diziam respeito à Primeira Praia). 


\subsection{Sessão de sensibilização e participação}

Para a recolha de informação para a realização do estudo, foi originalmente programada uma sessão de trabalho com a população. Após análise de material recolhido em momentos anteriores, nomeadamente para o "Estudo de Enquadramento Estratégico Costa da Trafaria" (2004) - que identificou problemas e conflitos territoriais - e na sessão "Mapeamento das Dunas da Cova do Vapor", realizada pelo projeto TransforMar (a 9 de junho de 2018) - onde foram apresentados e discutidos vários cenários de ação local para a proteção das dunas - considerou-se que o mais importante seria sensibilizar e informar os moradores sobre as propostas que estavam a ser estudadas pela equipa. A metodologia escolhida foi a de fazer uma breve apresentação sobre os dados históricos que se conhecem sobre a história da Cova do Vapor, seguida de uma dinâmica de jogo.

Desta forma, foi realizada, com o apoio da Associação Locals, que promoveu a dinâmica de jogo, uma sessão de uma tarde, no dia 29 de junho de 2019. A dinamização e divulgação da iniciativa foi feita, com o apoio da Biblioteca do Vapor, junto dos proprietários, residentes e da Associação de Moradores da Cova do Vapor. Estiveram presentes cerca de 20 pessoas na apresentação e 15 no jogo.

O jogo "Manual de Desenvolvimento Local Fórum Urbano" permite, através de uma dinâmica de jogo de cartas, em várias mesas, simular a construção de projetos para o desenvolvimento de estratégias de ação local. Foram organizadas 3 mesas, cada uma com um moderador, e propostos três problemas/áreas de intervenção, identificados pela equipa de investigação como fundamentais para a discussão do estudo: melhorar a mobilidade e acessibilidade na Cova do Vapor; criar condições para viver com o risco; proteção da duna.

Cada mesa identificou qual o projeto por onde desejava começar o jogo, dando uma ordem de prioridade aos problemas levantados e desenvolveu, com recurso às cartas do jogo, ou a cartas criadas no momento, potenciais soluções (primeiro individualmente e, depois, em grupo). A dinâmica decorreu dentro do previsto e todas as mesas participaram e cumpriram os objetivos do jogo (as fichas com a síntese podem ser consultadas em anexo). Sistematiza-se em seguida a forma como cada moderador documentou o processo:

Mesa 1: a ordem escolhida para debater os problemas foi mobilidade, risco, proteção da duna. Em todas as questões se insistiu na importância do envolvimento entre as entidades competentes. 0 grupo demonstrou muito desagradado com 0 congestionamento de carros que existe no verão devido aos veraneantes, e com a falta de respeito dos mesmos pelos moradores, sendo necessário controlar, e até proibir, esse tráfego. $\mathrm{O}$ grupo revelou-se muito participativo e empenhado em resolver as três questões, mostrando-se interessado em participar em iniciativas que possam vir a decorrer para resolver os problemas apresentados e deu importância à sua capacitação para resolver os problemas. Curiosamente, apesar de o grupo ter deixado o problema da duna para resolver no fim e ter dado prioridade ao problema da acessibilidade, no final, o grupo chegou à conclusão que devia ter começado pela questão da proteção da duna. 


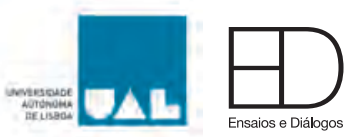

Mesa 2: o grupo entendeu que a questão da proteção da duna não estava bem formulada, por não se estar na presença de uma duna, e optou por não jogar a ronda relativa a essa questão, defendendo o avanço dos pontões e a permanência do estacionamento junto da duna para visitantes e utilizadores da praia. No cenário problema associado a viver com o risco, a possibilidade de incêndio e a impossibilidade de um camião tanque dos bombeiros entrar dentro da Cova do Vapor foi o cenário mais vezes referido.

Mesa 3: a escolha da ordem dos temas não foi consensual, tendo sido, por votação, escolhida a ordem proteger a duna, mobilidade e viver com o risco. $O$ grupo mostrou muito empenho na discussão e na dinâmica, levando o jogo até à forma final de elaboração de propostas individuais que resultam em projetos conjuntos, dando inclusive, nomes originais aos projetos criados. Dos três problemas colocados, o que despertou menos interesse foi o de criar condições para viver com o risco. Por oposição, houve grande interesse e empenho em propor soluções e pequenos projetos que contribuíssem para a solução dos problemas da mobilidade. A relação entre a proteção da duna e a melhoria da mobilidade e acessibilidades foi identificada prontamente. Em relação à relação com a gestão do risco, esse reconhecimento foi mais ténue.

O objetivo desta sessão foi fundamentalmente de consolidação das temáticas já trabalhadas e de observação da predisposição dos moradores para participar em soluções relacionadas com estes problemas.

Em relação à apresentação do esboço histórico, registou-se alguma resistência à aceitação de que muita da informação habitualmente veiculada é imprecisa e não está documentada, revelando a necessidade da promoção de mais investigação sobre esta área, enquadrando-a na história local.

No que diz respeito ao jogo, dois aspetos ficaram claros. Por um lado, a falta de consenso face à relação existente entre os três problemas. Por exemplo, não foi evidente para todos os participantes que a proteção da duna está ligada à solução dos problemas de mobilidade e acessibilidade à praia. Este aspeto é relevante, pois indica a necessidade de abordar melhor a complexidade de todo o ecossistema, aumentando a literacia ambiental, sobretudo porque, como alguns participantes frisaram, estas são temáticas de grande especificidade técnica. O outro aspeto foi a enorme disponibilidade e criatividade demonstrada por quase todos os presentes para poder ser parte ativa na solução (ou, pelo menos, em parte dela) dos problemas identificados.

A sessão confirmou o diagnóstico elaborado, dado que a maior parte das questões levantadas, não só no jogo, mas em paralelo, remetia para os três problemas definidos.

Por fim, dada a natureza informal do evento, ficou também registada a vontade de que algo mais formal fosse apresentado e de que algumas das ideias levantadas pudessem ser concretizadas no futuro. 


\section{Análise e discussão da situação de referência}

Pela sua localização privilegiada, no extremo noroeste do concelho de Almada, onde o Rio Tejo encontra o Oceano Atlântico, e pela ocupação de génese ilegal e de caráter sazonal, a Cova do Vapor está hoje sujeita a um conjunto de pressões naturais, económicas, sociais e administrativas que, num cenário temporal ainda incerto, vão contribuir para a transformação da sua composição urbana, natural e social. Esta condição, em constante mutação, resulta de fatores exógenos, como as intervenções feitas no rio Tejo ao longo de décadas (construção de barragens, dragagens) e os efeitos potenciais das alterações climáticas (aumento de fenómenos naturais extremos, subida do nível das águas do mar) mas também de fatores endógenos, como a pressão antrópica sobre o litoral (Mapa 8).

Em Portugal, o Regime Jurídico dos Instrumentos de Gestão do Território nem sempre tem sido capaz de oferecer soluções para as situações onde a proteção do território e do bem comum entram em conflito com a ocupação humana. Algumas tentativas recentes em áreas identificadas para realojamento mostraram que, embora algumas situações possam ser resolvidas, há conflitos de natureza persistente (Pereira, Ramalhete, 2017). Urge, portanto, criar mecanismos alternativos, ao nível regulamentar e ao nível da promoção da participação da população na resolução dos problemas do seu território. Este parece ser o caso da Cova do Vapor, dado que os Instrumentos de Gestão do Território em vigor perpetuam as disposições dos anteriores, que não conseguiram fornecer resposta adequada. Importa discernir duas questões que estando interligadas, são de natureza distinta. A primeira, a ocupação urbana atual, não é o objeto deste estudo. Contudo, com base na pesquisa efetuada, parece ser um tema que necessita de mais investigação e análise, nomeadamente o levantamento, discussão e procura de soluções.

A segunda, a que este estudo se dedica, é a proteção do litoral. Embora relacionada com a primeira, não depende completamente dela, dado que, dada a forte artificialização desta área de costa, esta terá sempre uma componente de intervenção humana. Ou seja, ainda que, um dia, o aglomerado deixe de existir naquela área, a proteção da zona costeira será sempre de elevada importância (tal como já acontece nas praias a sul da Cova do Vapor), até porque a pressão humana em época balnear irá, em princípio, manter-se. O facto de esta área ter uma população, parte dela permanente, deveria ser, para efeitos de proteção da zona, tido em conta não apenas como um problema, mas como um fator capaz de gerar soluções conjuntas - o que pode ser relevante para a preservação e regeneração das dunas, por exemplo, dado que a população já demonstrou no passado capacidade para resolver os seus problemas e conflitos territoriais. É, pois, imprescindível envolver a população local na definição de soluções para problemas cuja origem se perde já no tempo. Até porque aos conflitos territoriais com baixa capacidade de resolução, pela fragilidade da situação de referência, somam-se hoje problemas de escala global, como as alterações climáticas e a subida do nível médio das águas do mar. 
MAPA 8 - ÁREAS DE EXPOSIÇÃO AO GALGAMENTO E EROSÃO

ESC. $1 / 5000$

Duna

Rocha $\quad \boldsymbol{m a}$

\section{Galgamento}

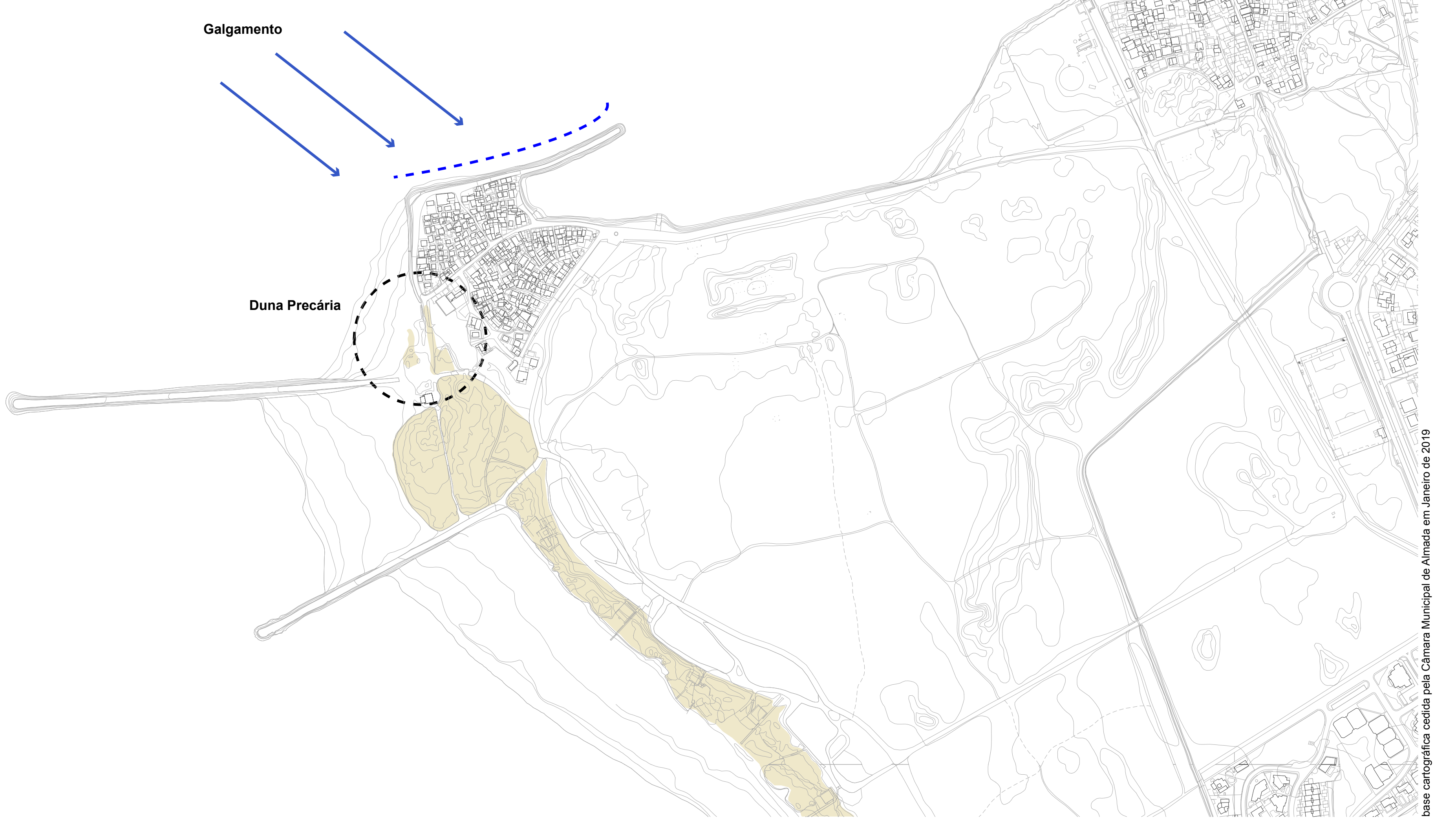




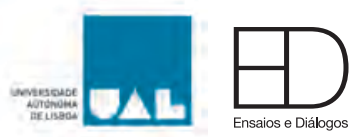

A análise da história desta área costeira revela fragilidade e constante mutação, mas também capacidade de adaptação às contingências de cada época. Um aspeto relevante é o facto de, apesar de alguma expansão urbana, haver alguma contenção que permite manter uma escala relativamente pequena e fácil de operar localmente. Este é um aspeto importante, pois a convivência com a situação de risco, sobretudo de tempestades durante o inverno, que afetam especialmente o lado norte da Cova do Vapor, é um tema ciclicamente presente, mas que tem sido alvo de pouco debate. Embora haja alguma perceção do risco, esta parece estar diluída num discurso de inevitabilidade.

A vocação balnear deste espaço como uma alternativa a áreas mais congestionadas, que esteve na origem da Cova do Vapor, é aquilo que, ainda hoje, atrai quem utiliza a praia. A situação de periferia face às praias mais procuradas, assim como a manutenção de caraterísticas como tranquilidade, ser familiar e segura, são aspetos valorizados por quem procura esta praia, muitas vezes já há várias décadas, oriundo sobretudo de Lisboa e Almada. Esta é também, tal como na sua génese, uma praia procurada por quem não pretende ter custos elevados com a sua deslocação, surgindo como uma alternativa a outras da Costa da Caparica. Como foi observado nos inquéritos realizados, a perceção de que esta é uma zona de risco e de que o cordão dunar é frágil e está degradado não é comum entre os utentes da praia (apesar de reconhecerem que as dunas devem ser protegidas). Estes são mais sensíveis à limpeza da praia do que à sua proteção, sendo claro que os esforços levados a cabo por iniciativas locais não foram ainda suficientes para aumentar o nível de consciência dos utilizadores da praia sobre este tema (embora os utilizadores da Primeira Praia sejam um pouco mais sensíveis à degradação da duna do que os da Praia da Cova do Vapor). A questão do estacionamento e da circulação na Cova do Vapor é, sem dúvida, um tema sensível, quer entre "banhistas" quer entre os moradores. Parece ser consensual a importância de garantir o acesso até à praia, mas há margem para debate, negociação, ensaio de soluções e até para iniciativas de sensibilização (durante a dinâmica de jogo, por exemplo, foi discutida a hipótese de "um dia sem carros").

É também importante referir que a Primeira Praia, pelo seu uso balnear reconhecido (apesar de não ser classificada como tal nem sujeita a plano de praia, nem tendo atualmente vigilância, possui caixotes do lixo diferenciados, embalagens e lixo comum, recolha regular de lixo e é alvo de limpeza regular da areia), e por pertencer ao mesmo sistema dunar tem de ser parte integrante de futuras análises e ações.

Em suma, se a localização geográfica em área de risco, os comportamentos face à deterioração da duna e a falta histórica de enquadramento ao nível dos Instrumentos de Gestão do Território podem ser considerados pontos fracos, por outro lado o enquadramento geográfico e paisagístico de grande valor e a existência de uma dinâmica social da população que pode ser parte das soluções encontradas são pontos fortes a considerar em ações futuras.

No que diz respeito à dinâmica dunar, é de realçar a importância ecológica desta área, assim como a capacidade de regeneração que ainda possui, mesmo na duna mais degradada. 


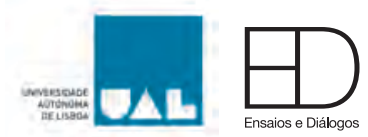

Mediante a caraterização anteriormente realizada dos valores ambientais e dos fatores ambientais e antrópicos, para este território, existem alguns fatores-âncora que constituem as ferramentas disponíveis para a programação do projeto de restauração ecológica, designadamente:

-as correntes marinhas semicirculares localizadas em frente a estas praias, auxiliadas pelos ventos dominantes de NNW, trazem uma quantidade relevante de sedimentos para a Praia da Cova do Vapor. O constante apport de sedimento é comprovado pelas espécies pioneiras ou primocolonizadoras que se instalam numa longa mas baixa frente dunar (mostra que está em construção);

- o sistema dunar a sul da Praia da Cova do Vapor tem um enorme potencial colonizador source para que, estando criadas as condições geomorfológicas básicas, a biodiversidade se instale nas dunas a norte do bar Albatroz;

- o sistema dunar da Primeira Praia tem uma duna alta a norte do pontão que separa a Primeira Praia da Cova do Vapor, que serve de âncora a todo o projeto de restauração ecológica desta frente de praias;

-existe uma área substantiva disponível entre a praia alta/base da duna e o parque de estacionamento/zona urbana que permite que a duna se possa formar e evoluir de forma seminatural e que possa acomodar alguma variação de perfil e localização em função dos fatores climáticos e oceanográficos incidentes; ou seja, a médio prazo a duna pode desenvolver-se com alguma flexibilidade e responder naturalmente aos fatores incidentes, ajustando-se. 


\section{Propostas}

No âmbito de estudo geral sobre a consolidação e proteção dunar na Cova do Vapor, procurou-se entender os efeitos da pressão exercida durante sobre o espaço natural e urbano, identificando as causas que explicam a situação atual.

A caraterização de aspetos como razões históricas, dinâmicas naturais, mobilidade, acessibilidade, espaço público, duna em consolidação e a capacidade de criar condições para viver com o risco permitiu que algumas das conclusões sejam apresentadas enquanto possíveis operações de melhoramento e qualificação do espaço natural e urbano da Cova do Vapor, definindo e protegendo os seus limites, enquanto se reduz a pressão existente sobre a duna em formação.

Nesse sentido, foi possível concluir que a necessária e urgente consolidação e proteção da frente dunar da Cova do Vapor deverá ser articulada com uma estratégia de mobilidade e acessibilidade que, trabalhando sobre o espaço urbano existente, direcione os moradores e visitantes para os acessos de praia existentes ou a criar, diminuindo o pisoteio sobre a estrutura dunar. Por outro lado, é também necessário começar a desenhar estratégias que acautelem danos causados por fenómenos naturais futuros. Em seguida, sistematiza-se um conjunto de propostas que, seguindo a linha de análise apresentada nos capítulos anteriores, poderão ancorar futuros projetos com o objetivo de promover os recursos culturais, naturais e paisagísticos na Cova do Vapor. A sua implantação territorial encontra-se sistematizada no Mapa 9.

\section{Restauro ecológico para proteção da linha de costa e reforço dos ecossistemas}

Em termos da dinâmica dunar, a área de intervenção carece de recuperação ambiental, na medida em que regista degradação da duna, agravada pelo seu uso intensivo, sobretudo durante a época balnear. É uma área com capacidade para que a duna se vá formando e crescendo, ajustando-se aos fatores climáticos, ambientais mas também à relação homem - natureza e ao uso do espaço. Para tal, é fundamental definir percursos e usos compatíveis, pois, a manter-se a tendência atual, a destruição da duna poderá ser definitiva.

No que diz respeito a ações futuras, é importante recordar os seguintes aspetos:

-existem sedimentos disponíveis;

-a duna frontal encontra-se degradada mas com uma área de duna alta que serve de âncora a todo o projeto;

-existe área a tardoz da duna primária disponível para que a duna se vá formando e crescendo ajustando-se aos fatores climáticos, ambientais mas também à relação homem - natureza e ao uso do espaço:

-existe curiosidade e interesse crescente da população e visitantes, com melhor perceção da importância dos sedimentos e dos sistemas dunares na proteção da linha de costa. No entanto, ainda não está consolidada, pelo que é fundamental continuar a desenvolver ações com este objetivo;

-é essencial serem definidos percursos de atravessamento do espaço dunar compatibilizados com a promoção da resiliência do ecossistema. 


\section{MAPA 9 - CENÁRIO FUTURO}

\section{ESC. 1/2000}

\section{Duna consolidada}

Acesso à praia

Área de recuo do apoio de praia*

Organização de bolsas de estacionamento e estacionamento informa

Área a estudar para a gestão do risco de galgamento/inundação

ש

*Programa da Orla Costeira Alcobaça - Cabo Espichel

Plano de Praia Cova do Vapor - São João da Caparica (adaptado)

Primeira Praia
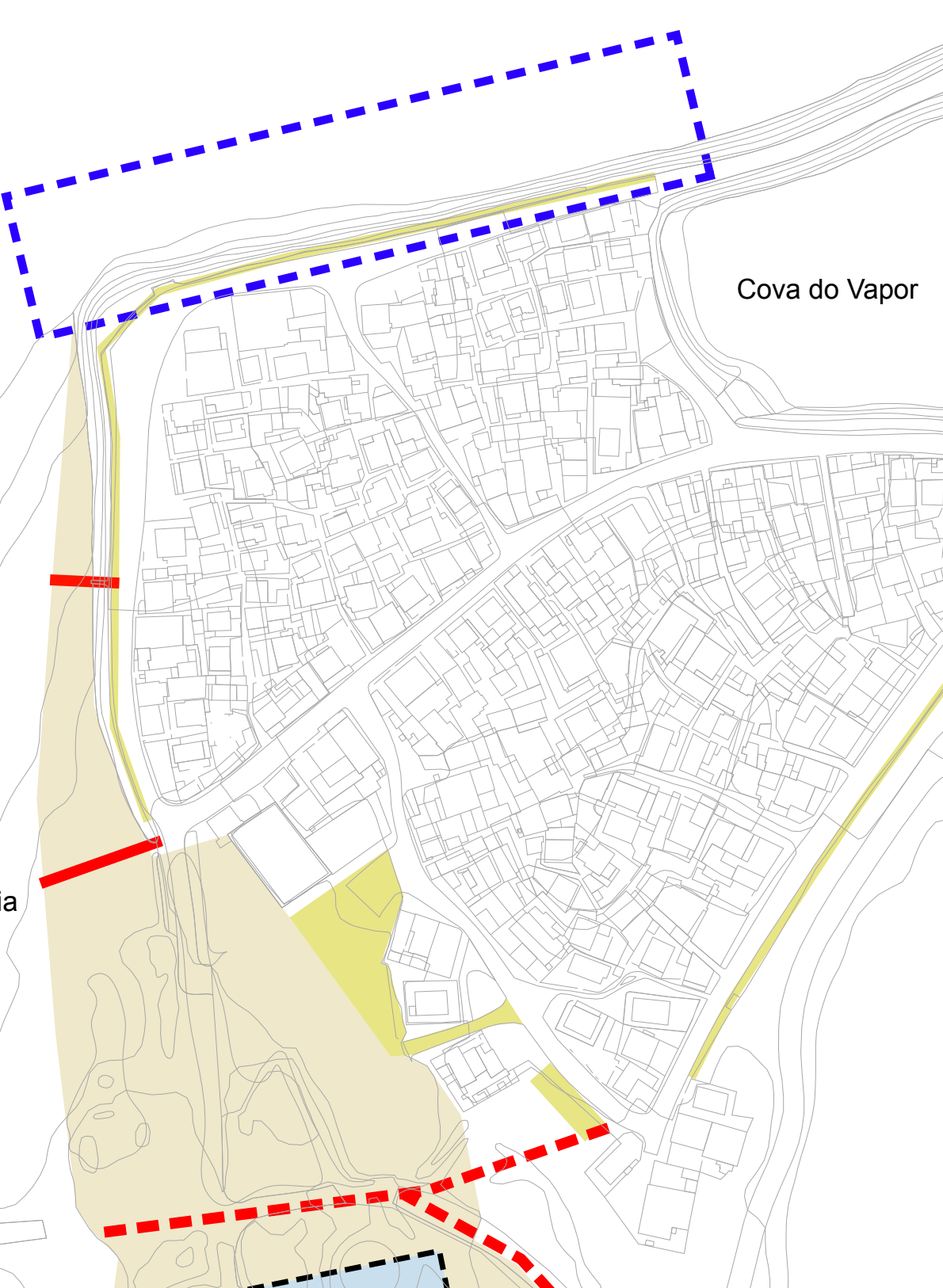


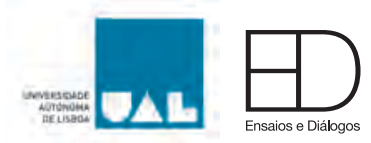

Acrescentam-se algumas recomendações, que poderão orientar as intervenções:

- o projeto de restauro ecológico da duna primária deve nascer a partir da duna âncora para norte, até à entrada da Primeira praia, pela Avenida António Martins Correia. 0 sistema dunar deve terminar, a norte, na base do enrocamento mais a norte da Primeira Praia. De preferência deve haver uma duna frontal vegetada a proteger o enrocamento (situação talvez só seja conseguida a médio prazo);

- o sistema dunar deve ter o menor número de interrupções;

- os caminhos pedonais secundários podem ter $1 \mathrm{~m}$ de largura, em passadiços sobre a duna;

- os passadiços de visitação (ex. percursos de acesso à praia, atravessamento do sistema dunar para as praias de São João, etc.) devem ter um mínimo de $2 \mathrm{~m}$ de largura para que duas pessoas possam caminhar lado a lado. Para garantir livre transgressão e crescimento da duna têm que ter cerca de $1 \mathrm{~m}$ de distância à cota atual da duna;

- as plantas de Ammophila arenaria são as ideais para construir e estruturar as dunas porque o seu sistema radicular cresce à medida que são soterradas. Espera-se podermos obter crescimento até $4 \mathrm{~m}$ de duna em três anos;

- as áreas de intervenção devem ser isoladas de qualquer atravessamento, para que haja a instalação e crescimento de novas plantas;

- as paliçadas de vime substituem as plantas na função de captura dos sedimentos, enquanto elas não estão suficientemente instaladas. São muito úteis também em termos paisagísticos, porque demonstram uma intervenção e uma intenção que garante geralmente o respeito pela intervenção.

\section{Criação de uma estratégia de mobilidade e acessibilidade que promova a proteção do litoral}

Apesar das incertezas em relação ao futuro do aglomerado urbano da Cova do Vapor e das dúvidas que possam existir relativamente ao direito e legitimidade daquela comunidade permanecer naquele território, a consolidação e proteção do litoral terá de ser assumida enquanto prioridade por todos os atores envolvidos (moradores, "banhistas", autarquias e poder central).

Para que a estratégia de Restauro ecológico para proteção da linha de costa e reforço dos ecossistemas tenha sucesso, é fundamental procurar solucionar a atual situação de circulação desregrada, provocada pelas condicionantes à mobilidade decorrentes da malha urbana, e pelo estacionamento em locais sem aptidão para o efeito e sem acesso orientado (por passadiço) à praia. Por outro lado, a resolução destes problemas poderá contribuir para o aumento da segurança, criando condições para o acesso de veículos de emergência, e para uma qualificação da mobilidade pedonal. Por fim, é importante combater a dicotomia morador/"banhista", de forma a envolver todos na resolução dos problemas. 


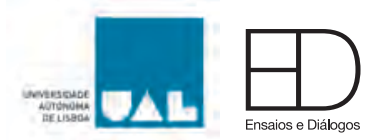

Acrescentam-se algumas recomendações, que poderão orientar as intervenções:

-assumindo os pressupostos do POC ACE, a praia da Cova do Vapor (sem considerar a Primeira Praia) tem uma capacidade de carga limitada (1200 utentes, 100 lugares de estacionamento);

-considera-se desejável, no futuro, o previsto recuo do apoio de praia existente. Nesta medida, parece razoável considerar a progressiva redução de área do estacionamento junto das praias, a definição e organização de áreas de estacionamento na entrada da Cova do Vapor e no interior do aglomerado urbano, assumindo um desenho e hierarquia que privilegie a mobilidade pedonal;

-a área de estacionamento reduzida junto das praias deverá ser reservada a veículos prioritários e a carga e descargas de pessoas e mercadorias.

A possibilidade de determinar hierarquias suaves nas vias que delimitam o aglomerado urbano deverá ser acompanhada por um estudo capaz de ponderar e gerir o risco de galgamento e inundação existente na zona norte da Cova do Vapor. A requalificação e beneficiação do molhe situado a norte e noroeste, muito fustigado pelas recentes tempestades, deve ser entendida como uma extensão do trabalho de consolidação e proteção do litoral. Este problema não está suficientemente presente nas preocupações dos moradores, no sentido é que é tido como uma inevitabilidade, para a qual não há margem de ação. Do ponto de vista da sua ocupação, esta área tem algum potencial de reorganização (em termos de ocupação do espaço público) e, de futuro, seria importante trabalhar com as entidades com responsabilidades na gestão da zona ribeirinha, no sentido de compreender melhor as dinâmicas existentes e, eventualmente, avaliar possíveis projetos de intervenção. Neste processo, a presença das associações locais é imprescindível. E embora seja uma temática em que estas têm uma capacidade de intervenção muito mais reduzida do que na proteção da duna ou na organização da circulação, poderão assumir o papel de catalisadores de futuros estudos (através de estágios, por exemplo), debates e, quem sabe, de soluções inovadoras.

\section{Nota final}

As propostas apresentadas neste resultam de uma análise e reflexão marcada no tempo e no espaço (2019), realizadas com a informação hoje disponível. Aquilo que, de futuro, venha a realizar-se terá - dada a dinâmica do litoral e deste território em particular - de ser adequado às circunstâncias que o tempo ditar. Neste contexto, importa referir a absoluta necessidade de continuar a envolver os moradores da Cova do Vapor nos projetos e nas tomadas de decisão, mas também de continuar a criar projetos em conjunto com as instituições locais (junta de freguesia, câmara municipal) e supralocais. 


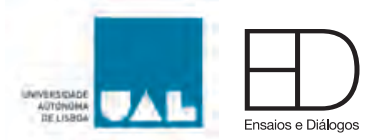

\section{Bibliografia}

AAVV - Estudo de Enquadramento Estratégico Costa da Trafaria. Parque Expo, Câmara Municipal de Almada, 2004.

ABREU, V. - O Porto de Lisboa e a Golada do Tejo. Síntese do Ciclo de Conferências "O Porto de Lisboa e a Golada do Tejo", conferência apresentada na Academia de Marinha. Lisboa: 2010.

Disponível em: https://www.idjc.pt/14pdf/O_PORTO_DE_LISBOA2.pdf

ANDRÉ, Isabel; VALE, Mário (coords) - A Criatividade Urbana na Região de Lisboa.

Relatório 4 - (versão preliminar) Case Studies. Lisboa: CCDR LVT, 2011. Disponível em https://issuu.com/ccdr-lvt/docs/relato_4_vp/49

Arquivo Histórico Municipal Câmara Municipal de Almada, Livro de Posturas, 1886, CMA/B/A/003/LV003.

BRAGA, Joana - Participatory Aesthetics and Makeshift Urbanism: cases of Guimarães, Cova do Vapor and Terras da Costa. In SHANKAR, Karin: LARSON, Kirsten (eds) Participatory Urbanisms: an anthology. São Francisco: University of Califórnia Press, 2015, p. 129-146.

CMA/DEGAS - Vulnerabilidade Costeira no Arco da Caparica: Avaliação do Troço Costeiro do Concelho de Almada, entre a Cova do Vapor e a Fonte da Telha. Análise das Campanhas de 2006 e 2010. Relatório Técnico. Almada, Portugal: 2010.

CEREJEIRA, José M. G. - Recuperar as praias da Caparica, Cruz Quebrada e Algés (parte 1). Revista da Marinha. 23 Julho, 2018. Disponível em: https://revistademarinha.com/tag/cova-do-vapor/

DIAS, Manuel Graça - Cova do Vapor. Qualquer coisa que suponho certa. Arquitectura Portuguesa. Revista Bimestral. Ano III, 5a série, n.o 11, 1987, p. 60-64.

FERREIRA, Ana Catarina de Sousa Louro - As Iniciativas de Intervenção Local dos Arquitetos: Oportunidades de Inovação Sócio-Territorial? Estudo de caso na Cova do Vapor. Dissertação submetida como requisito parcial para obtenção do grau de Mestre em Estudos Urbanos. Lisboa: ISCTE - Instituto Universitário de Lisboa, 2014.

FREIRE, M. E. - A planície litoral entre a Trafaria e a Lagoa de Albufeira. Dissertação de Mestrado em Geografia Física e Regional. Lisboa: Faculdade de Letras da Universidade de Lisboa, 1989.

Coastal Engineering 2004, pp. 3429-3441 (2005) REHABILITATION STUDY OF COASTAL DEFENSE WORKS AND ARTIFICIAL SAND NOURISHMENT AT COSTA DA CAPARICA, PORTUGAL. Coastal Engineering 2004

GOMES, Pedro Miguel; GUTIERRES, Francisco - Impact of Sea Level Rise on Coastal Regions and strategic Responses. In ENEANYA, Augustine Nduka - Handbook of Research on Environmental Management and Public Safety. USA: IGI Global, 2018, p. 239-255.

GTL - Relatório do Grupo de Trabalho Litoral. Gestão da Zona Costeira, o Desafio da Mudança. 4th December, 2014.

JUNIOR, Duarte Joaquim Vieira - Villa e Termo de Almada, apontamentos antigos e modernos para a história do Concelho. Vol. I. Lisboa: Imprensa Lucas, 1897. 


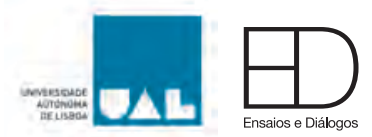

KULBERG, M. C.; KULBERG, J. C.; TERRINHA, P. - Tectónica da Cadeia da Arrábida. In: Tectónica das regiões de Sintra e Arrábida. Mem. Geociências, Museu Nacional de História Natural da Universidade de Lisboa. Lisboa: 2000, 2: 35-84.

LEAL, Carlos Barradas - Outrafaria. Trafaria: CAA, JUFCT, 2014.

LIRA, Cristina Ponte et al - Coastline evolution rates of Portugal. PANGAEA, 8 (1), 2016, p. 265-278.

LIRA, Cristina Ponte et al - Coastline evolution of Portuguese low-lying sandy coast in the last 50 years: an integrated approach. Earth System Science Data, 8(1), 265278.

MATEUS, Bruno Miguel Amaro - Como se organiza um bairro? Um estudo de caso sobre a Cova do Vapor (Trafaria). Dissertação submetida como requisito parcial para obtenção do grau de Mestre em Sociologia e Planeamento. Lisboa: ISCTEIUL, 2010.

OLIVEIRA, I. M. - Port of Lisbon improvement of the access conditions through the Tagus estuary entrance. Coastal Engineering Proceedings. 1992, 1(23).

OLIVEIRA, Marta Neves Simões Correia de - Evolução Natural e Antrópica. Trafaria Cova do Vapor - Costa de Caparica. Dissertação para a obtenção do Grau de Mestre em Arquitetura Paisagista. Lisboa: Instituto Superior de Agronomia, 2015.

PINTO, C.; TABORDA, R.; ANDRADE, C. - Evolução recente da linha costa no troço Cova do Vapor - S. João da Caparica. 5ạs Jornadas Portuguesas de Engenharia Costeira e Portuária. Lisboa, 2007.

RIBEIRO, Joana dos Santos Pires - Casas sem arquitecto. A cova do vapor, um caso de estudo sobre identidade e gosto popular. Porto: FAUP, 2015.

ROCHA, Jorge et al - A Hybrid CA-ANN-Fuzzy Model for Simulationg Coastal Changing Patters. In BOTERO, Camilo M; CERVANTES, Omar; FINKL, Charles W. (eds) Beach Management Toold - Concepts, Methodologies and Case Studies. USA: Springer, p. 197-218.

ROCHA, Miguel Afonso - Estruturação de áreas com valor ambiental e paisagístico na AML. Caso de estudo Polis Costa de Caparica. Dissertação para obtenção do grau de mestre em Arquitetura com especialização em Gestão Urbanística. Lisboa: Universidade Técnica de Lisboa - Faculdade de Arquitectura, 2011.

SANTOS, F. D.; Miranda, P. - Climate change in Portugal. Scenarios, impacts and adaptation measures - SIAM II Project. Lisboa: Gradiva, Técnico, 2006.

SAMPAIO, Ana et al - Environmental Conflicts in Portuguese Coastal Urban Areas: na Assessment. In KAHN, Ahmed Z. et al - Environmental Conflicts in Coastal Urban Areas, Towards a Strategic Assessment Framework for Sustainable Development. Itália: Sapienza Università Editrice, p. 173-201.

SEOANE, C. L. V.; FERNÁNDEZ, J. B. G; PASCUAL, C. V. - Manual de Restauración de Dunas Costeras. Santander, España: Ministerio de Medio Ambiente, Dirección General de Costas, 2007.

SILVA, A. N. et al - Entregável 1.2.2.2.b. Análise da evolução da linha de costa nos últimos 50 anos - caso especial da Costa da Caparica. Relatório Técnico, Projeto Criação e implementação de um sistema de monitorização no litoral abrangido pela área de jurisdição da Administração da Região Hidrográfica do Tejo. Lisboa: FFCUL/APA, I.P., Junho 2013. 


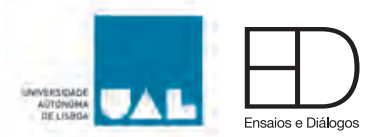

SILVA, P. Pinto da - Avaliação da vulnerabilidade Costeira no Concelho de Almada (Portugal). Tese de Mestrado em Gestão e Conservação da Natureza. Departamento de Ciências Agrárias. Universidade dos Açores, 2015.

SILVA, Raquel; GOMES, Fernando Veloso; BARBOSA, Joaquim Pais - Morphological Behaviour of Costa da Caparica Beaches Monitored during Nourishment Operations. Journal of Coastal Research: Special Issue 65 - International Coastal Symposium. Volume 2. 2013, p. $1862-1867$.

VASCONCELOS, L. M. T. D. (2015). Conflitos dos usos da água - Cova Do Vapor Almada - Portugal. XII Congresso Luso-Afro-Brasileiro (CONLAB) /10 Congresso Internacional de Ciências Sociais e Humanas em Língua Portuguesa (Abstract). Lisboa, Portugal: 2015.

VELOSO-GOMES, Fernando et al - As obras de defesa costeira na costa da Caparica. Na crista das ondas do mar e da comunicação social. 2.as Jornadas de Hidráulica, Recursos Hídricos e Ambiente. Porto: FEUP, 2007, p. 23-32.

VELOSO-GOMES, Fernando; TAVEIRA-PINTO, J. - Eurosion Case Study: Cova do Vapor, Costa da Caparica (Portugal). Porto: Instituto de Hidráulica e Recursos Hídricos IHRH. Universidade do Porto, 2002.

VELOSO-GOMES, Fernando et al - Estudo das intervenções na Costa Da Caparica. 1aas Jornadas de Hidráulica Recursos Hídricos e Ambiente. Porto: FEUP, 2006, p. 2735.

VELOSO-GOMES, Fernando; TAVEIRA-PINTO, F.; PAIS-BARBOSA, J. - Rehabilitation study of coastal defense works and artificial sand nourishment at Costa da Caparica, Portugal. Proceedings of the 29th International Conference Coastal Engineering 2004. Lisbon: National Civil Engineering Laboratory, 2005, p. 34293441.

\section{Instrumentos de Gestão do Território}

Programa da Orla Costeira Alcobaça - Cabo Espichel, Avaliação Ambiental Estratégica | Relatório Ambiental. Lisboa: Cedru, Biodesign, APA, abril 2017.

Programa da Orla Costeira Alcobaça - Cabo Espichel, Programa de execução e plano de financiamento. Lisboa: Cedru, Biodesign, APA, abril 2017.

Revisão do Plano Director Municipal, Estudos de Caracterização do Território Municipal. Caderno 1: Enquadramento Territorial. Almada: Câmara Municipal de Almada, outubro 2011.

Revisão do Plano Director Municipal, Estudos de Caracterização do Território Municipal. Caderno 2: Sistema Ambiental. Almada: Câmara Municipal de Almada, outubro 2011.

Revisão do Plano Director Municipal, Estudos de Caracterização do Território Municipal. Caderno 5: Sistema Urbano. Almada: Câmara Municipal de Almada, outubro 2011. 


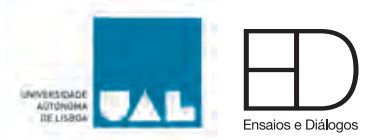

Revisão do Plano Director Municipal, Quadro prévio ao ordenamento. Almada: Câmara Municipal de Almada, novembro 2015.

\section{Artigos na imprensa periódica}

A construção de um quebra-mar na Cova do Vapor. Diário Popular. 30/01/1962.

A Cova do Vapor está ameaçada pelas águas... Diário da Manhã. 13/11/1950.

A cova do vapor não é um bairro da lata é um tesouro fantástico. Público. 24/07/2011.

As obras da praia da Costa de Caparica estão já devidamente planeadas. Diário Popular. 15/11/1968.

Avanço do mar. Diário de Notícias. 26/09/1968.

Caparica devagar se vai ao longe. Diário Popular. 13/10/1972.

Cova do Vapor com a casa às costas. Flama. 19/01/1962.

Cova do Vapor praia popular da margem sul deve á Parceria dos Vapores Lisbonenses o seu cómodo e fácil acesso. Século llustrado. 14/08/1948.

DIAS, Manuel Graça - Qualquer coisa que suponho certa, outra vez. Público. 15 de outubro de 2013. Disponível em:

https://www.publico.pt/2013/10/15/culturaipsilon/opiniao/qualquer-coisa-quesuponho-certa-outra-vez-1609102

Na reconstrução das barracas que o mar destruiu na Cova do Vapor trabalharam dezenas de estudantes universitários... O Século. 08/02/1962.

O mar avança sobre a terra. Século llustrado. 13/12/1958.

O mar enfurecido destruiu ou danificou 40 barracas da Costa da Caparica e Cova do Vapor. Diário Popular. 14/12/1958.

O mar invadiu as praias da Cova do Vapor e Caparica. Diário de Notícias. 15/12/1958.

O mar investiu furiosamente contra a Cova do Vapor e Caparica. O Século. 15/12/1958.

O poder popular em acção. Público. 28/04/2002.

Vai desaparecer a Cova do Vapor. Diário Popular. 17/01/1951. 


\section{Anexos}

- Tabela das ações da Biblioteca do Vapor para a sensibilização ambiental, desde 2017

. Inquéritos de utilização e perceção

. Fichas de projeto produzidas durante a sessão de sensibilização e participação 
Tabela das Ações da Biblioteca do Vapor para a sensibilização ambiental, desde 2017.

Siglas: AMC-Associaçăo Margem de Coragem; AMCV-Associação de Moradores da Cova do Vapor; BV- Biblioteca do Vapor (espaço fisico); CAA- Centro de Arqueologia de Almada; CEACT/UAL - Centro de Estudos de Arquitetura, Cidade e Território da Universidade Autónoma de Lisboa; CIIEECouncil on Internatita

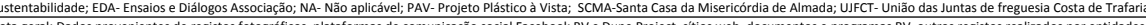
enlizados por entidades parceiras, candidaturas, entre outros.

\begin{tabular}{|c|c|c|c|c|c|c|c|}
\hline Mês/Ano & Ação & Local & Descrição & Objetivos/ Resultados & $\begin{array}{l}\text { Participantes/ } \\
\text { Público }\end{array}$ & $\begin{array}{c}\text { Colaboradores/ } \\
\text { Parceiros de } \\
\text { projeto }\end{array}$ & Observações \\
\hline Janeiro 2017 & 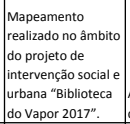 & $\begin{array}{l}\text { Açöes em todo o bairro } \\
\text { da Cova do Vapor }\end{array}$ & 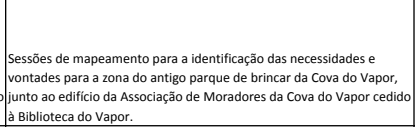 & $\begin{array}{l}\text { Recolla das ideias e opiniöes da populaçăo. Material recolhido de utilidade em } \\
\text { futuras intervenç̧ôs no bairro da Cova do Vapor, nomeadamente para o projeto } \\
\text { Transformar. }\end{array}$ & $\begin{array}{l}\text { Moradores da Cova do } \\
\text { Vapor de todas as idades }\end{array}$ & AMC; $A M C V ; B V ;$ & \\
\hline Fevereiro 2017 & \begin{tabular}{|l|} 
Candidatura do \\
projeto Transformar
\end{tabular} & NA & \begin{tabular}{|l|}
$\begin{array}{l}\text { Pedido de apoio pecuniário para projettos e eventos da Câmara } \\
\text { Municipal de Almada para o Desenvolvimento, gestão e produçăo de } \\
\text { projetos socioculturais, artisticos e desportivos }\end{array}$ \\
\end{tabular} & $\begin{array}{l}\text { Apoio monetárí para o desenvolvimento das açōes realizadas em } 2017 \text { pela } \\
\text { Biblioteca do Vapor, no âmbito do projeto TransforMar. }\end{array}$ & Beneficíário: AMC & NA & $\begin{array}{l}\text { Processo em curso } \\
\text { até à data. }\end{array}$ \\
\hline Abril 2017 & Transformar & Cova do Vapor & Inicio do projeto Transformar & Desenvolvimento da açöes da Biblioteca do Vapor & 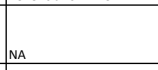 & Beneficiário: AMC & $\begin{array}{l}\text { Com o apoio } \\
\text { apalavado, inicia-se } \\
\text { oprojeto. }\end{array}$ \\
\hline Abril 2017 & Instalą̧ăo artistica & $\begin{array}{l}\text { Adjacente à Biblioteca } \\
\text { do Vapor }\end{array}$ & $\begin{array}{l}\text { Instalaçăo de estrutura artística para uso público e apoio das várias } \\
\text { açōes da Biblioteca do Vapor }\end{array}$ & $\begin{array}{l}\text { Promoçäo do espaço social da área adjacente à Associaçăo de Moradores e } \\
\text { Biblioteca do Vapor, respeitando as carateristicas ambientais do local, e } \\
\text { contribuindo para um melhor acesso e apoio cultural no bairro da Cova do Vapor. }\end{array}$ & $\begin{array}{l}\text { Voluntários do projeto } \\
\text { "Para Onde" e moradores } \\
\text { locais }\end{array}$ & $\begin{array}{l}\text { Projeto de voluntariado } \\
\text { internacional "Para } \\
\text { Onde"; Coletivo de } \\
\text { arquitetura Warehouse; } \\
\text { AMC; Casa de Hóspedes } \\
\text { Bugio à Vista }\end{array}$ & \begin{tabular}{|l} 
\\
Ação inserida no \\
aprograma \\
Transformar 2017 \\
\end{tabular} \\
\hline Abril 2017 & Sessão de filmes & \begin{tabular}{|l} 
Antigo Restaurante \\
Bugio àvista \\
\end{tabular} & Sessăo de filmes: Meio Ambiente e Pesca em Almada & $\begin{array}{l}\text { Aquisiçăo de conhecimentos sobre o meio ambiente marinho economia da pesca } \\
\text { em Almada. Sensibilizą̧ăo ambiental. Empoderamento através da aquisiç̧ăo de } \\
\text { conhecimento. }\end{array}$ & $\begin{array}{l}\text { Moradores da Cova do } \\
\text { vapor e participantes do } \\
\text { "Para Onde". }\end{array}$ & \begin{tabular}{|l|}
$\begin{array}{l}\text { AMC; CMA; Antigo } \\
\text { Restaurante Bugio à } \\
\text { Vista; Casa de Hóspedes } \\
\text { Bugio à Vista }\end{array}$ \\
\end{tabular} & $\begin{array}{l}\text { Açăo inserida no } \\
\text { programa } \\
\text { TransforMar } 2017\end{array}$ \\
\hline Abril 2017 & $\begin{array}{l}\text { Visita ao CMIA- } \\
\text { Aquário Virtual } \\
\end{array}$ & $\begin{array}{l}\text { CMIA Costa da } \\
\text { Caparica (Centro de } \\
\text { Monitorizaço e } \\
\text { Interpretaçăo de } \\
\text { Almada) }\end{array}$ & Visita guiada ao CMIA e ao Aquário Virtual & $\begin{array}{l}\text { Aquisiçăo de conhecimentos sobre o meio ambiente marinho em Almada. } \\
\text { Sensibilizaçao ambiental e usurruto de instalaç̧̄es públicas de valor cultural e para } \\
\text { a conservaçăo ambiental. }\end{array}$ & $\begin{array}{l}\text { Moradores da Cova do } \\
\text { vapor e da costa da } \\
\text { Caparica }\end{array}$ & AMC; DECAM-CMA & $\begin{array}{l}\text { Açăo inserida no } \\
\text { programa } \\
\text { TransforMar } 2017\end{array}$ \\
\hline Apr-17 & \begin{tabular}{|l|}
$\begin{array}{l}\text { Evolução da linha de } \\
\text { costa }\end{array}$ \\
\end{tabular} & Biblioteca do Vapor & $\begin{array}{l}\text { Apresentaçăo sobre o Tema das alteraçäes e evoluçăo da linha de } \\
\text { Costa entre a Trafaria e fonte da Telha, desde o último Máximo } \\
\text { Glaciário até à atualidade. }\end{array}$ & $\begin{array}{l}\text { Aquisiçăo de conhecimentos sobre geografia e geomorfologia locais, } \\
\text { empoderamento local e sensibilizaçăo ambiental através da aquisiç̧ăo de } \\
\text { conhecimento }\end{array}$ & $\begin{array}{l}\text { Moradores da Cova do } \\
\text { Vapor e visitantes }\end{array}$ & $\begin{array}{l}\text { AMCV; AMC; BV; } \\
\text { DECAM-CMA }\end{array}$ & $\begin{array}{l}\text { Açäoninseridata nos } \\
\text { objetivos do projeto } \\
\text { Transformar }\end{array}$ \\
\hline $\begin{array}{l}\text { Abril a } \\
\text { setembro } 2017\end{array}$ & $\begin{array}{l}\text { Instalaçăo do } \\
\text { Canteiro Dunarl/ } \\
\text { Canteiros ecológicos }\end{array}$ & $\begin{array}{l}\text { Espaço adjacente à } \\
\text { AMCV }\end{array}$ & 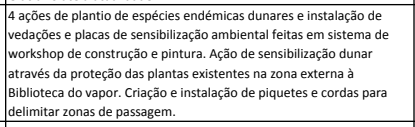 & 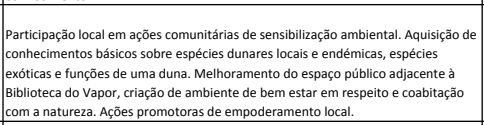 & $\begin{array}{l}\text { Moradores da Cova do } \\
\text { Vapor, participantes do } \\
\text { programa "Para Onde", } \\
\text { alunos da escola EB21 } \\
\text { Trafaria. }\end{array}$ & $\begin{array}{l}\text { AMCV; AMC; BV; } \\
\text { DECAM-CMA; Escola } \\
\text { EB21 Trafaria; "Para } \\
\text { Onde" }\end{array}$ & \begin{tabular}{|l} 
Açăo inserida no \\
programa \\
TransforMar 2017 e \\
nos objetivos do \\
projeto TransforMar
\end{tabular} \\
\hline $\begin{array}{l}\text { Abril e maio } \\
2017\end{array}$ & $\begin{array}{l}\text { Conhecer o Projeto } \\
\text { Reduna }\end{array}$ & BV e praia de Săo João & $\begin{array}{l}2 \text { sessōes: apresentaçăo do projeto Reduna. Sessão de } \\
\text { esclarecimentos sobre dinâmicas sedimentares e ecossistemas } \\
\text { dunares seguido de visita guiada ao Projeto Reduna na praia de São } \\
\text { Joăa. }\end{array}$ & $\begin{array}{l}\text { Sensibilizaçăo ambiental e empoderamento local através da aquisiçăo de } \\
\text { conhecimento cientifico. Divulgą̧ăo de projeto vizinho de cariz ambiental. }\end{array}$ & $\begin{array}{l}\begin{array}{l}\text { Moradores da Cova do } \\
\text { Vapor e visitantes }\end{array} \\
\end{array}$ & $\begin{array}{l}\text { AMC; AMCV; BV; } \\
\text { DECAM-CMA }\end{array}$ & \begin{tabular}{|l} 
BV programa \\
primavera 2017; \\
Ação inserida nos \\
objetivos \\
Transformar e no \\
Programa \\
TransforMar 2017 \\
\end{tabular} \\
\hline Juho 2017 & \begin{tabular}{|l|} 
Encontros da Terra \\
e do Mar
\end{tabular} & Cova do Vapor, BV & $\begin{array}{l}\text { Projeto NOVOS DEEISORES ClêNCIAS - ciência cidadă do Estuário do } \\
\text { Tejo entre geólogos costerios e habitantes do Segundo Torrăo, } \\
\text { Trafafria, Almada. }\end{array}$ & $\begin{array}{l}\text { Divulgação de projeto vizinhho sobre as alteraçōes geomorfológicas da Zona Trafaria } \\
\text { Costa da Caparica, aquisiçăo de novos conhecimentos sobre o tema. }\end{array}$ & $\begin{array}{l}\text { Moradores da Cova do } \\
\text { appor e do Segundo } \\
\text { Torräo }\end{array}$ & $\begin{array}{l}\text { AMC; AMCV; BV; NOVOS } \\
\text { DECISORES CIENECIAS; }\end{array}$ & \begin{tabular}{|l} 
BV programa verão \\
2017; Açắo inserida \\
nos objetivos \\
Transformar
\end{tabular} \\
\hline Setembro 2017 & $\begin{array}{l}\text { Candidatura para o } \\
\text { projeto } \\
\text { Transformart }\end{array}$ & o & $\begin{array}{l}\text { Realizaç̃o de candidatura no âmbito do programa MAR2020-GAL } \\
\text { ADREPES COSTELRO-Programa Operacional Mar 2020 - Execuçăo das } \\
\text { Estratégia DLBC. }\end{array}$ & 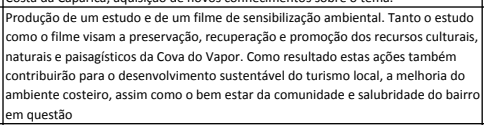 & $\int_{\text {NA }}$ & Beneficiário: EDA & $\begin{array}{l}\text { Cofinanciamento } \\
\text { acordado em Junho } \\
\text { de } 2018\end{array}$ \\
\hline $\begin{array}{l}\text { Fevereiro e } \\
\text { març de } 2018\end{array}$ & $\begin{array}{l}\text { Campanha de } \\
\text { Angariaçäo de } \\
\text { Fundos online }\end{array}$ & NA & 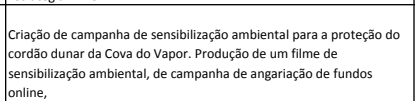 & 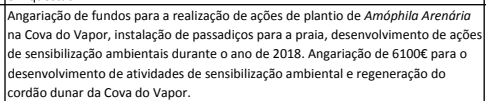 & $\begin{array}{l}\text { 104 doadores, } 6100 € \\
\text { arrecadados }\end{array}$ & $\begin{array}{l}\text { AMC; Artistas e } \\
\text { moradores locais; Casa } \\
\text { de hóspedes Bugio à } \\
\text { Vista; The Dune project; }\end{array}$ & \begin{tabular}{|l} 
Ação inserida nos \\
objetivos \\
Transformar
\end{tabular} \\
\hline Março 2018 & Limpeza de praia & $\begin{array}{l}\text { Torrão a Cova do } \\
\text { vapor }\end{array}$ & 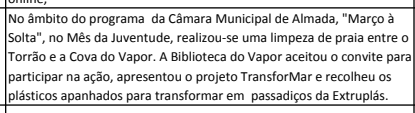 & $\begin{array}{l}\text { Participaçăa em inincicativas de sensibilização ambiental vizinhas. Apresentação do } \\
\text { TransforMar a um publico alargado, recolha de material para aquisiçăo de } \\
\text { passadiços da Extruplás para o acesso à praia, recolha de lixo em zona dunar } \\
\text { realizado da forma menos invasiva possivel, minimimizando os estragos produzidos } \\
\text { por recolha de lixo mecânica. }\end{array}$ & $\begin{array}{l}120 \text { participantes da } \\
\text { limpeza }\end{array}$ & $\begin{array}{l}\text { AMC; AMCV; Brigada do } \\
\text { Mar; Novo Mundo; } \\
\text { CMA; Dune Project; EDA }\end{array}$ & $\begin{array}{l}\text { Açăo inserida no } \\
\text { projeto Transformar }\end{array}$ \\
\hline Abril 2018 & \begin{tabular}{|l|}
$\begin{array}{l}\text { Ação de limpeza de } \\
\text { praia + Aula de } \\
\text { Stand-Up Paddle }\end{array}$ \\
\end{tabular} & $\begin{array}{l}\text { Baía do Porto de Abrigo } \\
\text { da Cova do Vapor }\end{array}$ & $\begin{array}{l}\text { Atividade de limpeza de praia juntamente com experiência de Stand- } \\
\text { Up Paddle. Atividade gratuita na qual se apresentou o projeto } \\
\text { TransforMar e falou de questöes ambientais, tais como a poluição nos } \\
\text { mares e a subida dos niveis do mar }\end{array}$ & $\begin{array}{l}\text { Sensibilizaç̃ã e responsabilização de moradores e utilizadores da baía da Cova do } \\
\text { vapor para o problema do lixo produzido. }\end{array}$ & $\begin{array}{l}30 \text { participantes - } 25 \\
\text { adultos } \mathrm{e} 5 \text { jovens entre } \\
\text { os } 10 \text { e } 17 \text { anos. } 2 \text { jovens } \\
\text { moradores da Cova do } \\
\text { Vapor } 28 \text { utentes } \\
\text { regulares da praia da Cova } \\
\text { do Vapor e São Joăo }\end{array}$ & $\begin{array}{l}\text { AMC; AMCV; Dune } \\
\text { Project; EDA; Escola de } \\
\text { Ia Stand-Up Paddle "Stand } \\
\text { Up Friend Padle"; UJFCT; }\end{array}$ & $\begin{array}{l}\text { Ação inserida no } \\
\text { Programa } \\
\text { TransforMar 2018; }\end{array}$ \\
\hline Abril 2018 & $\begin{array}{l}\text { Sessão de } \\
\text { mapeamento das } \\
\text { dunaa da Cova do } \\
\text { Vapor }\end{array}$ & $\begin{array}{l}\text { Aç̄es em todo o bairro } \\
\text { da Cova do Vapor }\end{array}$ & 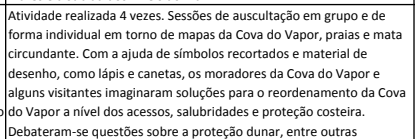 & 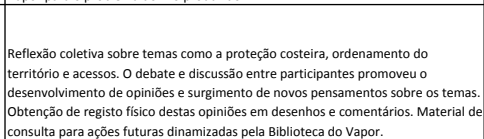 & $\begin{array}{l}\text { Aproximadamente } 50 \\
\text { pessoas, } \\
\text { maiortariamente adultos } \\
\text { moradores da Cova do } \\
\text { Vapor. Das } 50 \text { pessoas, } \\
\text { eparticiparam } 5 \text { crianças } \mathrm{e} \\
15 \text { visitantes. }\end{array}$ & $\begin{array}{l}\text { AMC; AMCV; BV; } \\
\text { DEAM-CMA Dune } \\
\text { Project; EDA; UJFCT }\end{array}$ & $\begin{array}{l}\text { Aç̆o inserida no } \\
\text { Programa } \\
\text { TransforMar } 2018\end{array}$ \\
\hline Maio 2018 & Mesa de votos & $\begin{array}{l}\text { Espaço recreativo de } \\
\text { convivio da AMCV }\end{array}$ & 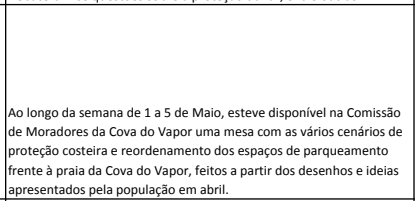 & 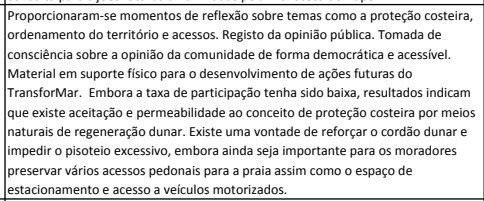 & $\begin{array}{l}25 \text { votos, apenas } \\
\text { moradores da Cova do } \\
\text { Vapor. }\end{array}$ & $\begin{array}{l}\text { AMC; AMCV; DECAM- } \\
\text { CMA; Dune Project }\end{array}$ & $\begin{array}{l}\text { Açăo inserida nos } \\
\text { objetivivs } \\
\text { Transformar; Apoio } \\
\text { Crowdfunder }\end{array}$ \\
\hline Maio 2018 & $\begin{array}{l}\begin{array}{l}\text { Workshop de placas } \\
\text { de sensibilizaçăo } \\
\text { ambiental }\end{array} \\
\end{array}$ & \begin{tabular}{|l} 
Antigo restaurante \\
Bugio à Vista
\end{tabular} & \begin{tabular}{|l|} 
Desenho e construçãoo da sinalizaçẵo de sensibilizzaçăo para as dunas \\
da Cova do Vapor
\end{tabular} & 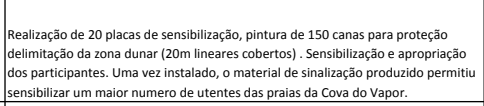 & $\begin{array}{l}13 \text { pessoas. } 3 \text { crianças da } \\
\text { Cova do Vapor } 10 \\
\text { adultos utentes da praia } \\
\text { da Cova do Vapor }\end{array}$ & $\begin{array}{l}\text { AMC; AMCV; artista } \\
\text { plástica Silvie da Costa; } \\
\text { Casa de Hóspedes Bugio } \\
\text { à Vista; DECAM-CMA } \\
\text { Dune Project; UJFCT; }\end{array}$ & $\begin{array}{l}\text { Açă i inserida no } \\
\text { Programa } \\
\text { Transformar 2018; } \\
\text { apoio Crowdfunder }\end{array}$ \\
\hline Maio 2018 & $\begin{array}{l}\text { Workshop } \\
\text { "caminhos } \\
\text { ecológicos para a } \\
\text { praia" }\end{array}$ & \begin{tabular}{|l} 
Dunas da Cova do \\
Vapor
\end{tabular} & $\begin{array}{l}\text { Construçăo e delimitaçăo dos caminhos entre as dunas da Cova do } \\
\text { vapor, através da instalą̧ăo das placas e canas realizadas no workshop } \\
\text { anterior }\end{array}$ & 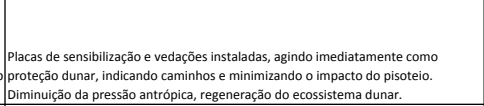 & $\begin{array}{l}15 \text { pessoas - } 5 \text { Crianças e } \\
10 \text { adultos, utentes da } \\
\text { Cova do Vapor }\end{array}$ & $\begin{array}{l}\text { AMC; AMCV; artista } \\
\text { plástica Silvie da Costa; } \\
\text { Casa de Hóspedes Bugio } \\
\text { à Vista; DECAM- CMA; } \\
\text { Dune Project; UJFCT } \\
\end{array}$ & $\begin{array}{l}\text { Ação inserida no } \\
\text { Programa } \\
\text { Transformar 2018; } \\
\text { apoio Crowdfunder }\end{array}$ \\
\hline Maio 2018 & Aula de surf & \begin{tabular}{|l} 
Espaço 20 Costa da \\
Caparica
\end{tabular} & 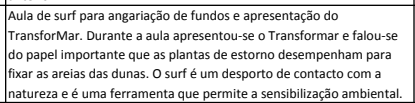 & 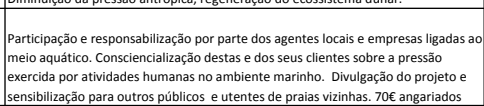 & $\begin{array}{l}10 \text { pessoas dos } 14 \text { aos } 46 \\
\text { anos. }\end{array}$ & $\begin{array}{l}\text { AMC; AMCV; DECAM- } \\
\text { CM; Dune Projec; EDA; } \\
\text { Escola Espaço 20 Costa } \\
\text { da Caparica; UJFCT }\end{array}$ & $\begin{array}{l}\text { Aç̄o inserida no } \\
\text { Programa } \\
\text { Transformar } 2018\end{array}$ \\
\hline io 2018 & \begin{tabular}{|l} 
Apresentação \\
publica do \\
Transformar
\end{tabular} & & $\begin{array}{l}\text { Apresentaçăa Pública do Transformar no âmbito da divulgaçăo do } \\
\text { workshop in situ/ } 8 \text { Cova do Vapor }\end{array}$ & $\begin{array}{l}\text { Angariaçăo de alunos para o workshop in situ/n na Cova do Vapor no âmbito do } \\
\text { projeto Transformar, em julho } 2018 \text {. }\end{array}$ & $\begin{array}{l}3 \text { alunos do } \\
\text { Departamento de } \\
\text { Arquitetura da } \\
\text { Universidade Autónoma } \\
\text { de Lisboa }\end{array}$ & $\begin{array}{l}\text { AMC; AMCV; DECAM- } \\
\text { CMA; ; DUne Project EDA. } \\
\text { CEACT/UAL UJFCT }\end{array}$ & $\begin{array}{l}\text { Açăo inserida no } \\
\text { Programa } \\
\text { Transformar } 2018\end{array}$ \\
\hline lunho 2018 & Limpeza de praia & $\begin{array}{l}\text { Primeira Praia e Praia } \\
\text { do Albatroz }\end{array}$ & $\begin{array}{l}\text { Limpeza de praia do Dia dos Oceanos. Os plásticos recolhidos serão } \\
\text { Transformados em passadiços de praia pela empresa de } \\
\text { transformaçăo de residuos plásticos, EXTRUPLÁs }\end{array}$ & $\begin{array}{l}\text { Sensibilizacāão por parte dos utentes presentes na açăo, para o problema do lixo } \\
\text { nas praias, em particular para o problema do plástico, Recolha de matéria prima } \\
\text { para fabrico de passadicos EXTRUPLÁS para a praia. }\end{array}$ & 16 adultos estrangeiros & $\begin{array}{l}\text { AMC; AMCV; Casa de } \\
\text { Hóspedes Bugio à Vista; } \\
\text { DECAM-CMA; Dune } \\
\text { Project; EDA; UJFCT; } \\
\text { Surfrider's Foundation }\end{array}$ & \begin{tabular}{|l} 
A A̧ăo inserida no \\
Programa \\
Transformar 2018; \\
apoio Crowdfunder
\end{tabular} \\
\hline
\end{tabular}




\begin{tabular}{|c|c|c|c|c|c|c|c|}
\hline Junho 2018 & \begin{tabular}{|l|} 
Apresentaçăo \\
Pública do \\
TransforMar + \\
limpeza das dunas \\
da Cova do Vapor
\end{tabular} & \begin{tabular}{|l} 
Dunas da Cova do \\
Vapor
\end{tabular} & 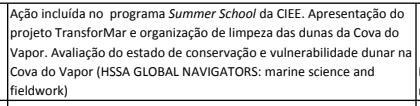 & $\begin{array}{l}\text { Envolver alunos estrangeiros numa açăo local de preservaçãa ecológica através da } \\
\text { realização prática de açōes de proteçăo costeira }\end{array}$ & $\begin{array}{l}38 \text { participantes - alunos } \\
\text { adolescentes do } \\
\text { programa de verão da } \\
\text { ClEE }\end{array}$ & $\begin{array}{l}\text { AMC; CIEE; DECAM- } \\
\text { CMA; Dune Project; } \\
\text { EDA; UJFCT }\end{array}$ & \begin{tabular}{|l} 
Aç̧ăo inserida no \\
Programa \\
Transformar 2018
\end{tabular} \\
\hline Junho 2018 & $\begin{array}{l}\text { Workshop de placas } \\
\text { de sensibilizaçă } \\
\text { ambiental }\end{array}$ & $\begin{array}{l}\text { Primeira Praia e Antigo } \\
\text { restaurante Bugio à } \\
\text { Vista }\end{array}$ & 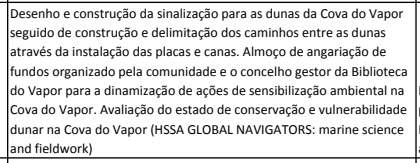 & 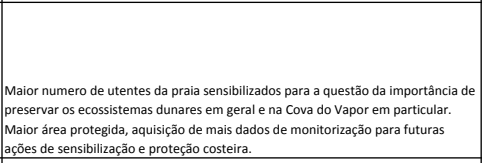 & $\begin{array}{l}38 \text { participantes. Alunos } \\
\text { adolescentes do } \\
\text { programa de verão da } \\
\text { CIEE }\end{array}$ & $\begin{array}{l}\text { AMC; Casa de Hóspedes } \\
\text { Bugio à Vista; CIEE; } \\
\text { DECAM-CMA; Dune } \\
\text { Project; EDA; UJFCT; }\end{array}$ & \begin{tabular}{|l} 
Ação inserida no \\
Programa \\
TransforMar 2018
\end{tabular} \\
\hline Junho 2018 & \begin{tabular}{|l} 
Festa de Angariaçăo \\
de fundos do \\
projeto Transformar
\end{tabular} & $\begin{array}{l}\text { Praia do Golfinho costa } \\
\text { da Caparica }\end{array}$ & Festa de Angariaçăo de fundos do projeto Transformar. & 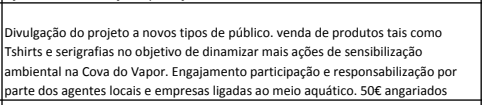 & \begin{tabular}{|l|} 
mais de 50 participantes, \\
clientes do \\
estabelecimento Choco \\
Frrito e Praia do Golfinho \\
na Costa da Caparica \\
\end{tabular} & \begin{tabular}{l|} 
AMC; Choco Frrito; Dune \\
Project; EDA; UJFCT;
\end{tabular} & $\begin{array}{l}\text { Ação inserida no } \\
\text { Programa } \\
\text { TransforMar } 2018 \\
\end{array}$ \\
\hline Julho 2018 & $\begin{array}{l}\text { Aç̧̧̃o de limpeza de } \\
\text { praia + Aula de } \\
\text { Standup Padle }\end{array}$ & $\begin{array}{l}\text { Praia Baía do Porto da } \\
\text { Cova do Vapor }\end{array}$ & $\begin{array}{l}\text { Atividade de limpeza de praia com experiencia de Stand-Up Paddle } \\
\text { Board. Atividade dividida em } 2 \text { grupos, que se revezaram. Ambos os } \\
\text { grupos limparam a praia e experimentaram andar nas pranchas. } \\
\text { Atividade gratuita }\end{array}$ & $\begin{array}{l}\text { Sensibilização e responsabilizaç̃ã de moradores e utilizadores da Baía da Cova do } \\
\text { vapoor para o problema do lixo como poluente tóxico e visual. }\end{array}$ & $\begin{array}{l}30 \text { participantes - } 25 \\
\text { adultos } 5 \text { jovens entre } \\
\text { os } 10 \text { e } 17 \text { anos. } 2 \text { jovens } \\
\text { moradores da Cova do } \\
\text { Vapor e } 28 \text { utentes } \\
\text { regulares da praia da Cova } \\
\text { do Vapor e São João }\end{array}$ & \begin{tabular}{|l|} 
\\
AMC; Dune Project; \\
EDA; Escola local de \\
Stand-Up Paddle "Stand \\
Up friend Padle"; UJFCT
\end{tabular} & $\begin{array}{l}\text { Ação inserida no } \\
\text { Programa } \\
\text { TransforMar } 2018\end{array}$ \\
\hline Julho 2018 & $\begin{array}{l}\begin{array}{l}\text { Participaçăo Blue } \\
\text { Dot Generation }\end{array} \\
\end{array}$ & $\begin{array}{l}\begin{array}{l}\text { Praia da Cova do Vapor } \\
\text { e BV }\end{array} \\
\end{array}$ & 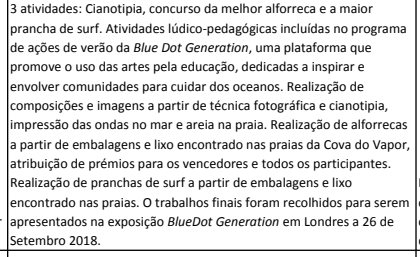 & $\begin{array}{l}\text { Espera-se que, através de açōes nas quais se trabalha a capacitaçăo e a } \\
\text { criatividade, os participantes desenvolvam a sensibilizaçăo ambiental e se tornem } \\
\text { conscientes da sua responsabilidade na preservaçăo do ambiente, particularmente } \\
\text { do ambiente marinho e costeiro onde vivem. }\end{array}$ & \begin{tabular}{|l} 
Cianotipia: 10 jovens do \\
$22^{\circ}$ Torrăo entre os 7 e os \\
14 anos; Concurso da \\
melhor alforreca: 12 \\
jovens do 2 -Torräo entre \\
os 7 e os 14 anos. \\
Atividade "Pranchas de \\
surf de plástico": 15 \\
jovens do 20 Torrão entre \\
os 7 e os 14 anos \\
\end{tabular} & $\begin{array}{l}\text { AMCV; AMC; Blue dot } \\
\text { generation; BV; Dune } \\
\text { Project; projeto Sai e } \\
\text { Age SCMA } \\
\end{array}$ & \begin{tabular}{|l} 
Açăo inserida no \\
programa Dune \\
Project/ objetivos \\
TransforMar; apoio \\
Crowdfunder
\end{tabular} \\
\hline Julho 2018 & $\begin{array}{l}\text { Arranque de chorão } \\
\text { e controlo de } \\
\text { acácias }\end{array}$ & $\begin{array}{l}\text { Primeira praia e Praia } \\
\text { da Cova do Vapor }\end{array}$ & $\begin{array}{l}\text { Ação de restauraçăo ecológica } \\
\text { einterveņ̧ăo Ambiental }\end{array}$ & $\begin{array}{l}\text { Remoçăo de um volume considerável de chorăo, aproximadamente } 4 \mathrm{~m} 3 \\
\text { equivalentes a uma área de } 30 \mathrm{~m} 2 \text {, uma área de duna e mata com aproximada } \\
\text { mente } 800 \mathrm{~m} 2 \text {. Sensibilizaçăo a um maior número de utentes da praia, minimizaçăo } \\
\text { da pressão exercida nos ecossistemas dunares pela vegetaçăo invasora. }\end{array}$ & $\begin{array}{l}55 \text { participantes - alunos } \\
\text { adolescentes do } \\
\text { programa de verão da } \\
\text { CIEE }\end{array}$ & $\begin{array}{l}\text { AMC; CIIE; DECAM, } \\
\text { DESA, DIACS-CMA; DUne } \\
\text { Project; EDA; UJFCT }\end{array}$ & \begin{tabular}{|l} 
Açăo inserida no \\
Programa \\
TransforMar 2018
\end{tabular} \\
\hline Julho 2018 & $\begin{array}{l}\text { in situ/ } 8 \text { Cova do } \\
\text { Vapor }\end{array}$ & \begin{tabular}{|l|} 
Primeira praia, Praia da \\
Cova do Vapor e espaço \\
adjacente à Associação \\
de Moradores da Cova \\
do Vapor
\end{tabular} & 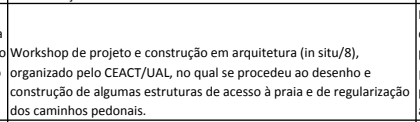 & 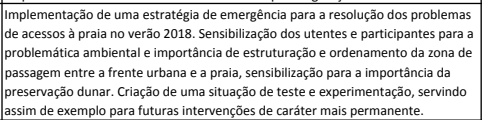 & $\begin{array}{l}15 \text { alunos do curso de } \\
\text { arquitetura da UAL }\end{array}$ & $\begin{array}{l}\text { AMC; AMCV; BV; } \\
\text { CEACT/UAL; Dune } \\
\text { Project; EXTRUPLAS; }\end{array}$ & $\begin{array}{l}\text { Açăo inserida no } \\
\text { Projeto TransforMar } \\
\text { 2018; Crowdfunder }\end{array}$ \\
\hline Janeiro 2019 & $\begin{array}{l}\begin{array}{l}\text { Ação Cuidar da } \\
\text { praia da Cova do } \\
\text { vapor }\end{array} \\
\end{array}$ & $\begin{array}{l}\text { Primeira praia e Praia } \\
\text { da Cova do Vapor }\end{array}$ & 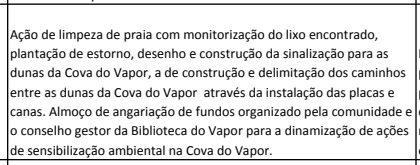 & 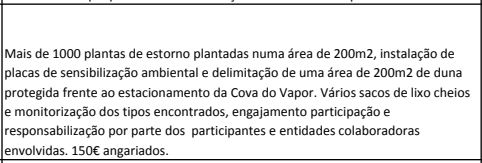 & $\begin{array}{l}53 \text { participantes, com } \\
\text { idades entre o } 8 \text { e os } 65 \\
\text { anos, grupos de familias } \mathrm{e} \\
\text { amigos, moradores da } \\
\text { Cova do Vapor e } \\
\text { visitantes utentes da } \\
\text { praia. }\end{array}$ & \begin{tabular}{|l|} 
AMC; ;MCV; Alma \\
Naturista; Associaçăo \\
Novo Mundo; B; \\
Brigada do Mar; DECAM, \\
DESA, DIACS-CMA; \\
Dune Project; EDA; \\
Museu da Paisagem; \\
UJfCT \\
\end{tabular} & \begin{tabular}{|l} 
Ação inserida nos \\
objetivos \\
TransforMar; \\
donativo de 1000 \\
plantas de estorno \\
DESA, DIACS-CMA
\end{tabular} \\
\hline $\begin{array}{l}\text { Janeiro a } \\
\text { setembro } 2019\end{array}$ & Produção de filme & NA & \begin{tabular}{|l|} 
Filme de sensibilização ambiental "casa Cova" produzido no âmbito do \\
projeto Transformart
\end{tabular} & 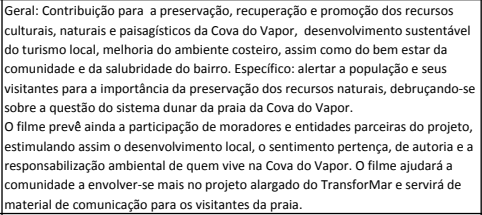 & $\begin{array}{l}8 \text { figurantes, vozes do } \\
\text { filme. } 6 \text { moradores locais, } \\
2 \text { moradores da Costa da } \\
\text { Caparica }\end{array}$ & \begin{tabular}{|l|} 
AMC; Casa de Hospedes \\
Bugio à Vista; DESA, \\
DiACS- CMA; Duna \\
Films; EDA
\end{tabular} & \begin{tabular}{|l} 
Cofinanciado pelo \\
Mar 2020 - GAL \\
ADREPES COSTEIRO- \\
PRIORIDADE \\
EXECUCĀAO DAS \\
ESTRATÉGIAS DE \\
DESENVOLVIMENTO \\
LOCAL DE BAE \\
COMUNITÁRIA; \\
Beneficíario EDA \\
\end{tabular} \\
\hline $\begin{array}{l}\text { Janeiro a } \\
\text { setembro } 2019\end{array}$ & $\begin{array}{l}\text { Realização de } \\
\text { estudo }\end{array}$ & NA & Estudo realizado no âmbito do projeto TransforMart & 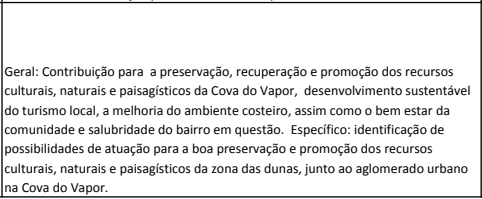 & NA & $\begin{array}{l}\text { AMC; AMCV; CAA; } \\
\text { CEACT/UAL; DACS-CMA } \\
\text { EDA }\end{array}$ & \begin{tabular}{|l} 
Cofinanciado pelo: \\
Mar 2020 - GAL \\
ADREESS COSTEIRO- \\
PRIORIDADE 4 \\
EXECUCĀÄO DAS \\
ESTRATÉGIAS DE \\
DESENVOLVIMENTO \\
LLCALDE BAE \\
COMUNITARIA; \\
Beneficíario EDA \\
\end{tabular} \\
\hline
\end{tabular}




\section{Estudo de atuação e promoção dos recursos culturais, naturais e paisagísticos na Cova do Vapor Inquérito de utilização e perceção (não residentes) \\ (v2.0 --2019)}

\section{P
VAPOR}

1.1. Quando veio pela primeira vez à praia à Cova do Vapor?

O É a primeira vez

O há um ano ou menos

O entre dois a cinco anos

O há mais de dez anos

O desde sempre

1.2. Tendo o último ano (incluindo verão de 2018) como referência, quantas vezes veio à praia à Cova do Vapor?

O 1

O 2-5

O 6-10

$\mathbf{O}>10$

O n/a (se é primeira vez)

1.3. Está alojado na Cova do Vapor?

O Não

O Sim, em casa ou quarto alugado

- Sim, em casa de amigos ou familiares

1.4. Como chegou à Cova do Vapor?

O Transporte próprio - carro

O Transporte próprio - mota

O Transporte próprio - bicicleta

O Transporte coletivo - autocarro

O A pé - vindo do barco

O A pé - vindo de outro local

O Outro:

1.5. Se veio em transporte próprio, onde estacionou?

O No parque à entrada

O No parque junto à praia

O No interior do aglomerado

O Outro:

\subsection{Com quem veio?}

\author{
O Sozinho \\ O Com a família \\ O Com amigos \\ O Outro:
}

\subsection{Por onde acedeu à praia?}
O Pelo acesso da rua principal
O Pelo acesso junto ao restaurante Albatroz
O Atravessou a duna junto à biblioteca
O Pelo acesso de São João
O Outro:

1.8. Porque escolheu esta praia?
O Pela tranquilidade
O Pela paisagem
O Por tradição
O Por ser diferente
O Porque não conhecia
- Estacionamento sem custos $\mathbf{0}$ Para fazer surf
O Por ter amigos ou família aqui
O Outra:

1.9. Quanto tempo vai hoje permanecer na praia?
$\mathbf{O}<2 \mathrm{~h}$
O 1 manhã ou tarde
O Todo o dia

1.10. Além da praia, irá usufruir de outros espaços (assinalar sim)?

O Cafés / padaria

O Outro comércio

O Biblioteca

O Outro

1.11. Quanto estima que gastou/vai gastar $(€)$ nesta visita (transporte e alimentação)?
$0<10$
O $11-20$
O $21-30$
$0>30$ 
2. PERCEÇÃo E POTENCIAL DE MOBILIZAÇÃo INDIVIDUAL

2.1. Classifique de 1 (muito mau) a 5 (muito bom) as seguintes condições da praia da Cova do Vapor:

\begin{tabular}{|l|l|l|l|l|l|}
\hline & 1 & 2 & 3 & 4 & 5 \\
\hline Acesso à CV & & & & & \\
\hline Estacionamento & & & & & \\
\hline Acesso à praia & & & & & \\
\hline Comércio CV & & & & & \\
\hline Apoios de praia & & & & & \\
\hline Vigilância & & & & & \\
\hline Estado das dunas & & & & & \\
\hline Limpeza da praia & & & & & \\
\hline Qualidade da água & & & & & \\
\hline
\end{tabular}

2.2. Tem conhecimento de que a praia Cova do Vapor se localiza numa zona de risco (tempestades)?

O Sim. Qual?

O Não

2.3. Na sua opinião, qual o estado de conservação das dunas da Cova do Vapor?
O Muito destruído
O Razoável
O Bom
O NS/NR

2.4. Considera que é importante proteger as dunas da praia Cova do Vapor?
O Sim
O Não
O Talvez
O NS/NR

2.5. Classifique de 1 (nada disposto) a 5 (totalmente disposto) se estaria disposto a:

\begin{tabular}{|l|l|l|l|l|l|}
\hline & 1 & 2 & 3 & 4 & 5 \\
\hline Estacionar fora da CV & & & & & \\
\hline Vir de bicicleta & & & & & \\
\hline Pagar o estacionamento & & & & & \\
\hline $\begin{array}{l}\text { Fazer um caminho mais longo } \\
\text { pela CV para chegar à praia }\end{array}$ & & & & & \\
\hline $\begin{array}{l}\text { Aceder à praia através de um } \\
\text { passadiço }\end{array}$ & & & & & \\
\hline $\begin{array}{l}\text { Participar numa campanha de } \\
\text { plantio }\end{array}$ & & & & & \\
\hline $\begin{array}{l}\text { Participar numa apanha de } \\
\text { lixo }\end{array}$ & & & & & \\
\hline
\end{tabular}

2.6. Na sua opinião, que medidas podiam ser tomadas para proteger as dunas?

\subsection{O que tem pior a praia da Cova do Vapor?}

\subsection{E de melhor?}

\subsection{0 que faz mais falta?}

2.9. Conhece o projeto REDUNA (Praia de São João)?

O Sim.

O que conhece?

O Não

O NS/NR

\section{DADOS PESSOAIS}

PARA NOS AJUDAR A COMPREENDER OS VISITANTES DA PRAIA TEMOS ALGUMAS PERGUNTAS PESSOAIS QUE NÃO DEIXAM DE GARANTIR O ANONIMATO DO INQUIRIDO.

Idade: Género: O M O F

Concelho de Residência:

Código Postal:

Habilitações Académicas
O 10 ciclo
O 20 ciclo
O 3 ciclo
O Ensino secundário ou equivalente
O Ensino superior

Profissão:

\section{FICHA INQUIRIDOR (nome)}

Inquérito $\mathrm{n}$. 으

Local

O Praia norte

O Praia sul

Data Hora

Contagem pessoas na hora certa anterior

Comentários 
pujeco Tronzfortyser

\section{Ficha de Proieto}

1. Nome Protecroa do dewa.

\section{Metas:}

\section{Recursey actosturias}

a) Recursos limanos-Camunidode, APL, copitanic, Veronecontes, Pescodores

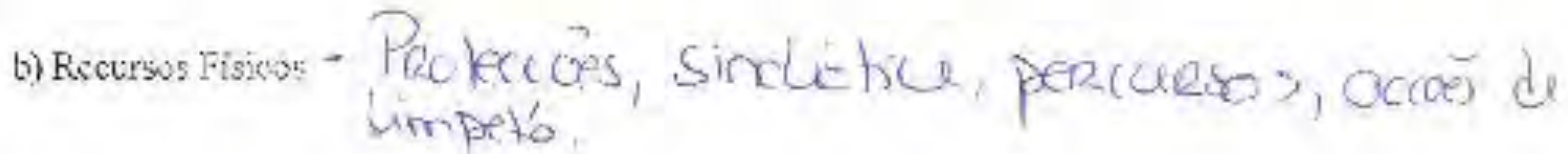

\section{Tempo is: Faccucath}

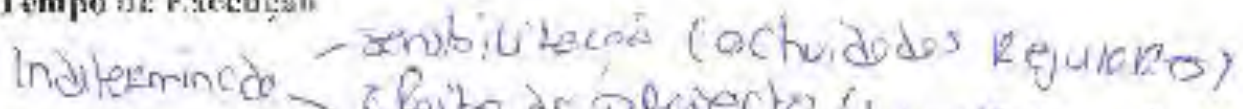

5. Benefie thritia
a) Muadries (1: residonciai
b) Moradoces 2 resoldecia)
civisiturtes
(1) Tuklos:

\section{Parceinas:}

\section{Projete}

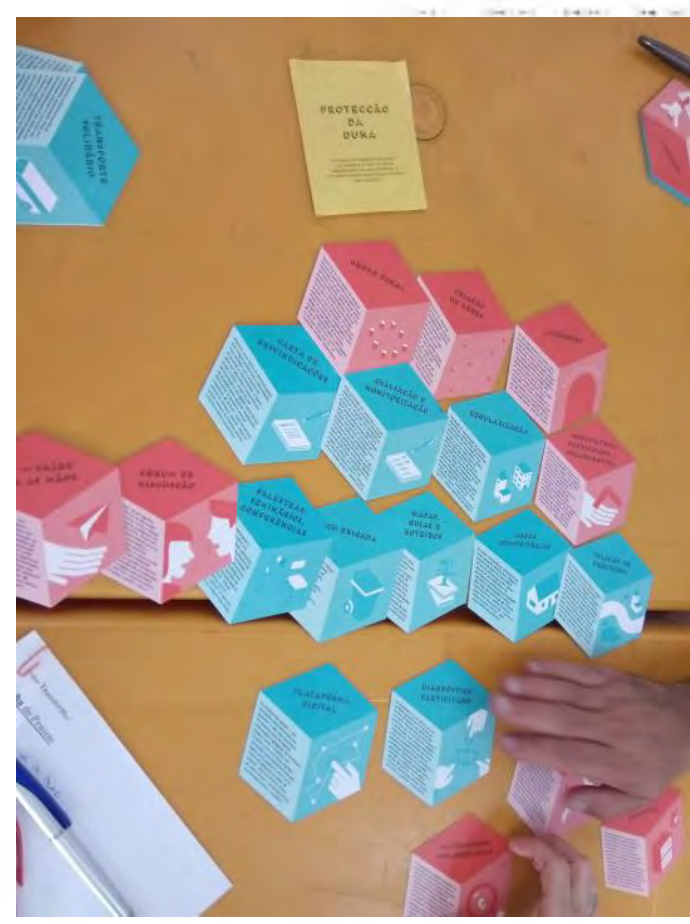


prujec Tramaformin

\section{Ficha de Prolicto}

\section{Nome: cruore cende coes porb wiven com obisco \\ 2. Hetas:}

3. Recursw nectssarites

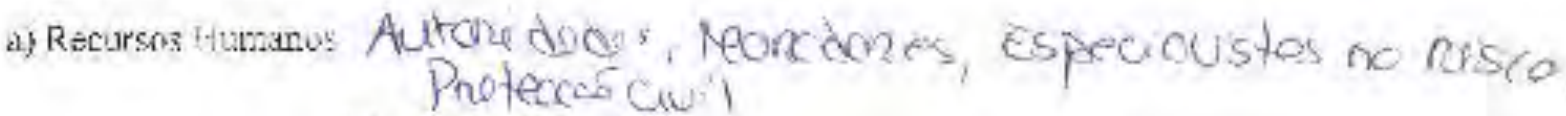

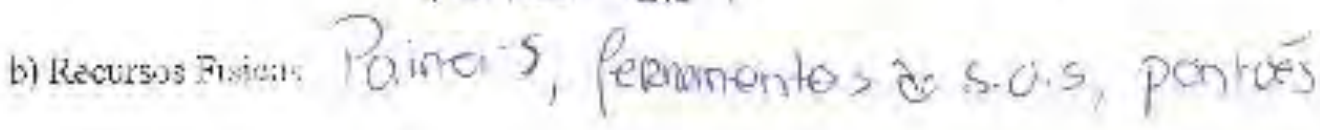

4. Tempo is Frerugse

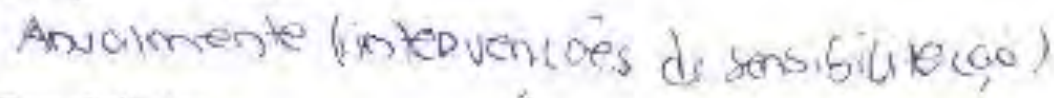

5. Benefietartin

a) Hiradores 1 1" rosidtong'?

h) Morado es $\left(2^{2}\right.$ nusicential?

c) Visilunite:

d) Todíst:

$\alpha$

\section{Parcetiras:}

\section{Projicto}

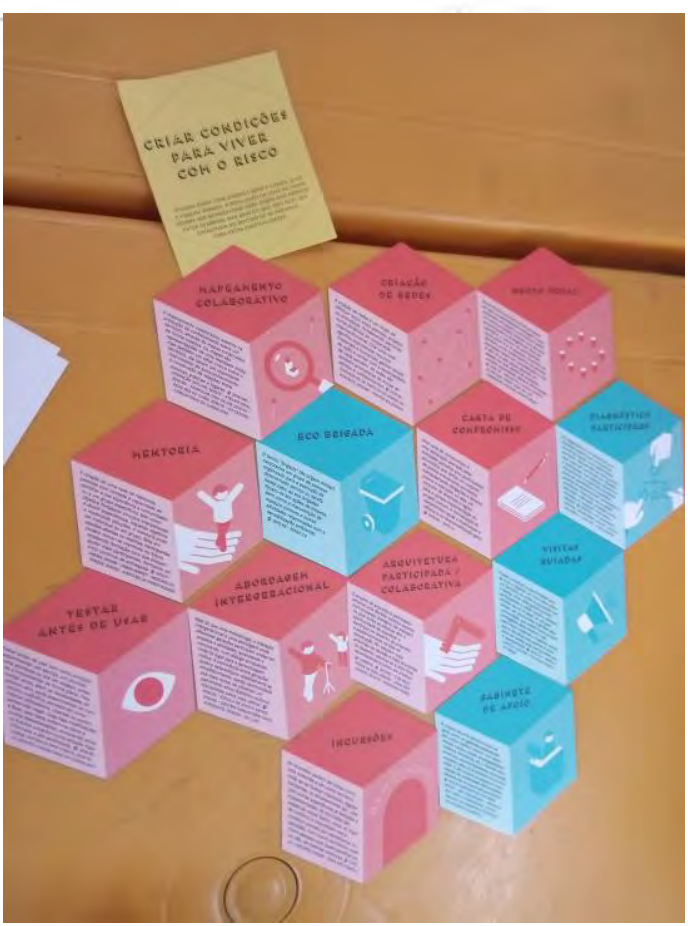


project Transiforivlar

\section{Ficha de Proieto}

1. Nume: Methuro do moridade. Aass sili des de

2. Meras: de cous de vapoz

\section{Recursos aecessáticis}

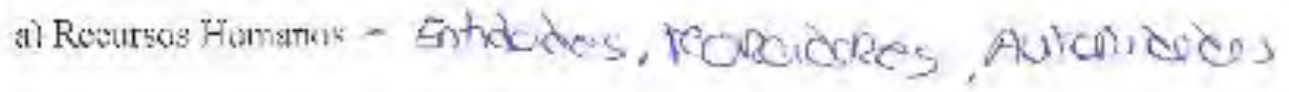

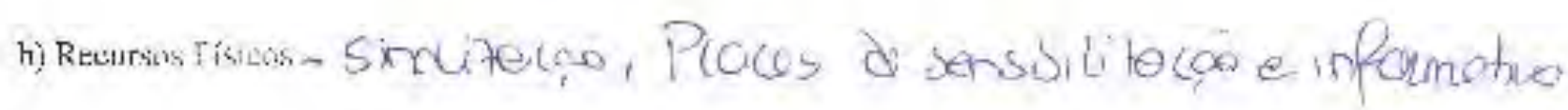

4. Tempo de Txeco tut

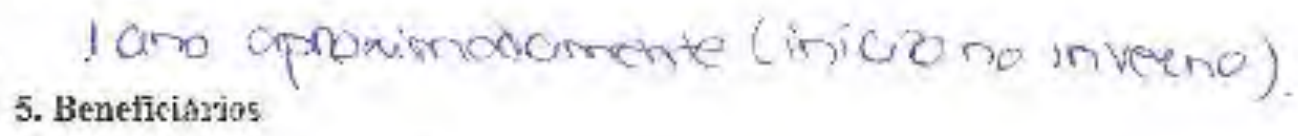

a) M(oradors (" restutencia)

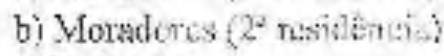

c) Visitanses

d) Todas

$\alpha$

6. Partecin: Autoridodos e Entidudos

7. Prajeto

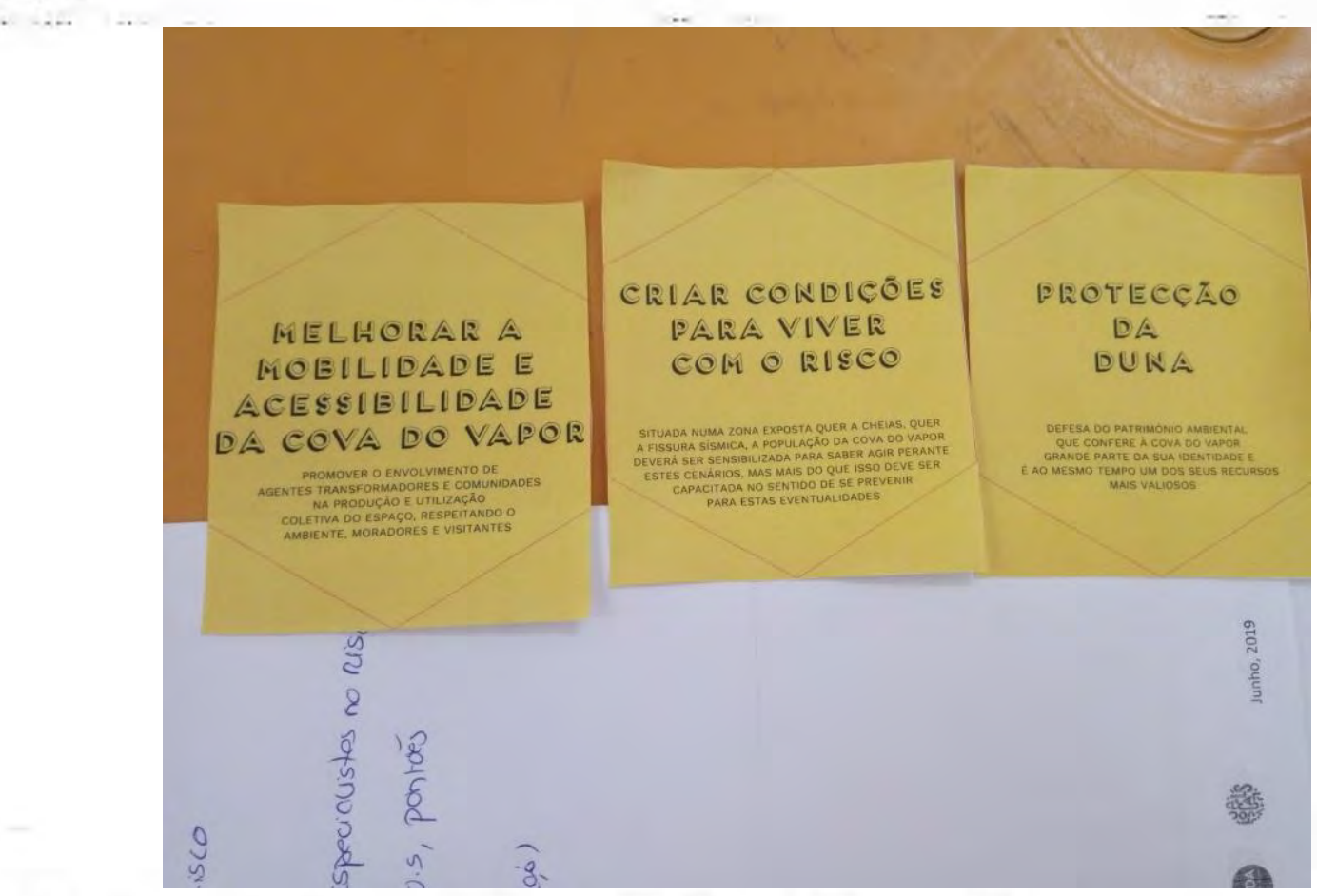

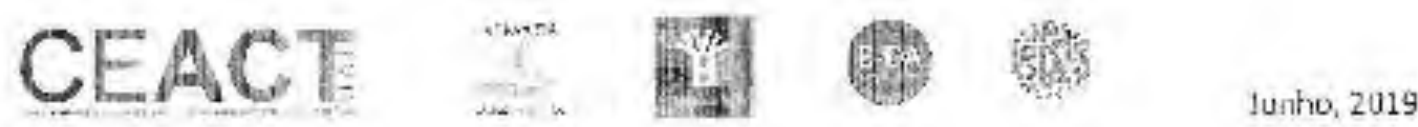




\section{Ficha de Projeto}

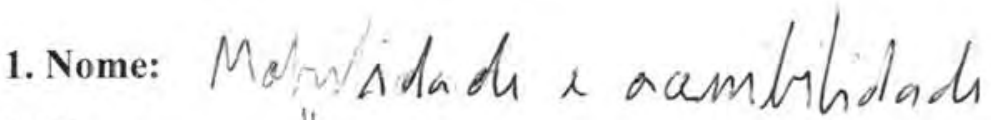

2. Metas: santhorar as a anos a a ciamiacino

\section{Recursos necessários}

a) Recursos Humanos

b) Recursos Físicos

4. Tempo de Execução

$$
\text { a } n \operatorname{tin} \pi
$$

\section{Beneficiários}

a) Moradores ( $1^{\mathrm{a}}$ residência)

b) Moradores ( $2^{\mathrm{a}}$ residência)

c) Visitantes

d) Tod@s

\section{$X$}

6. Parceiros: L'M. Almada, youtt, APL, Assoviagüa de Morndores, Bamburos,

7. Projeto GNR

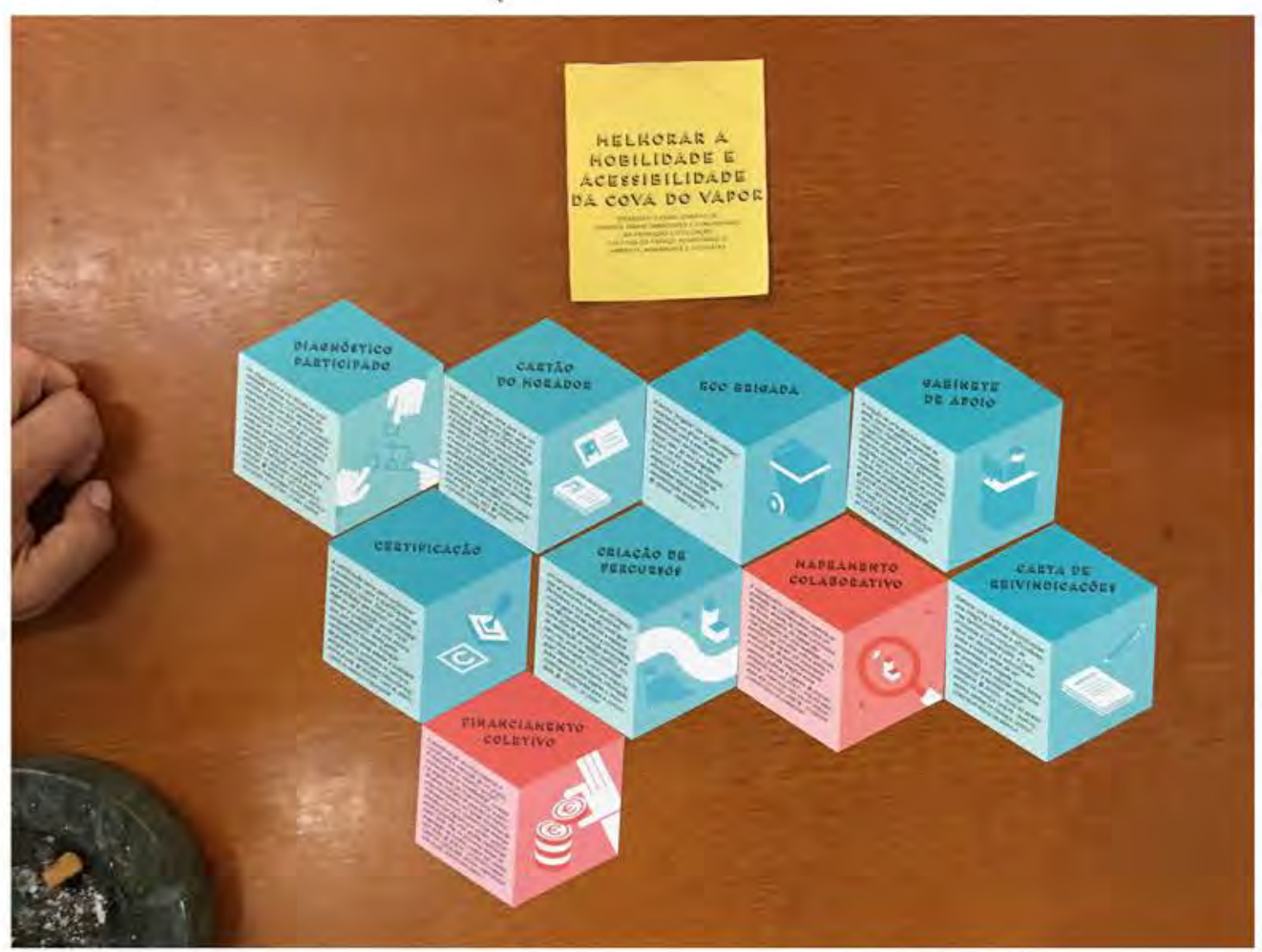


projeto TransforMar

\section{Ficha de Projeto}

1. Nome: Viver can o risco

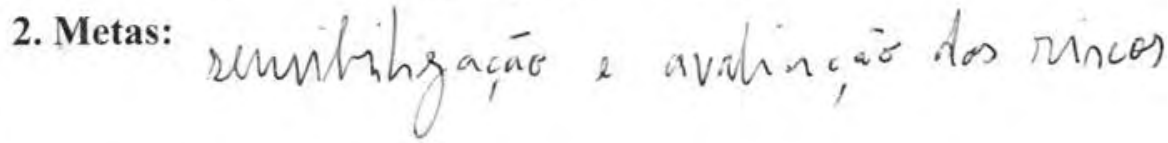

3. Recursos necessários

a) Recursos Humanos

b) Recursos Físicos

4. Tempo de Execução

$$
\text { a definis }
$$

\section{Beneficiários}

a) Moradores ( $1^{\mathrm{a}}$ residência)

b) Moradores ( $2^{\mathrm{a}}$ residência)

c) Visitantes

d) Tod@s

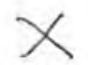

6. Parceiros: Anosincar al Moradares, Briblioteca

7. Projeto
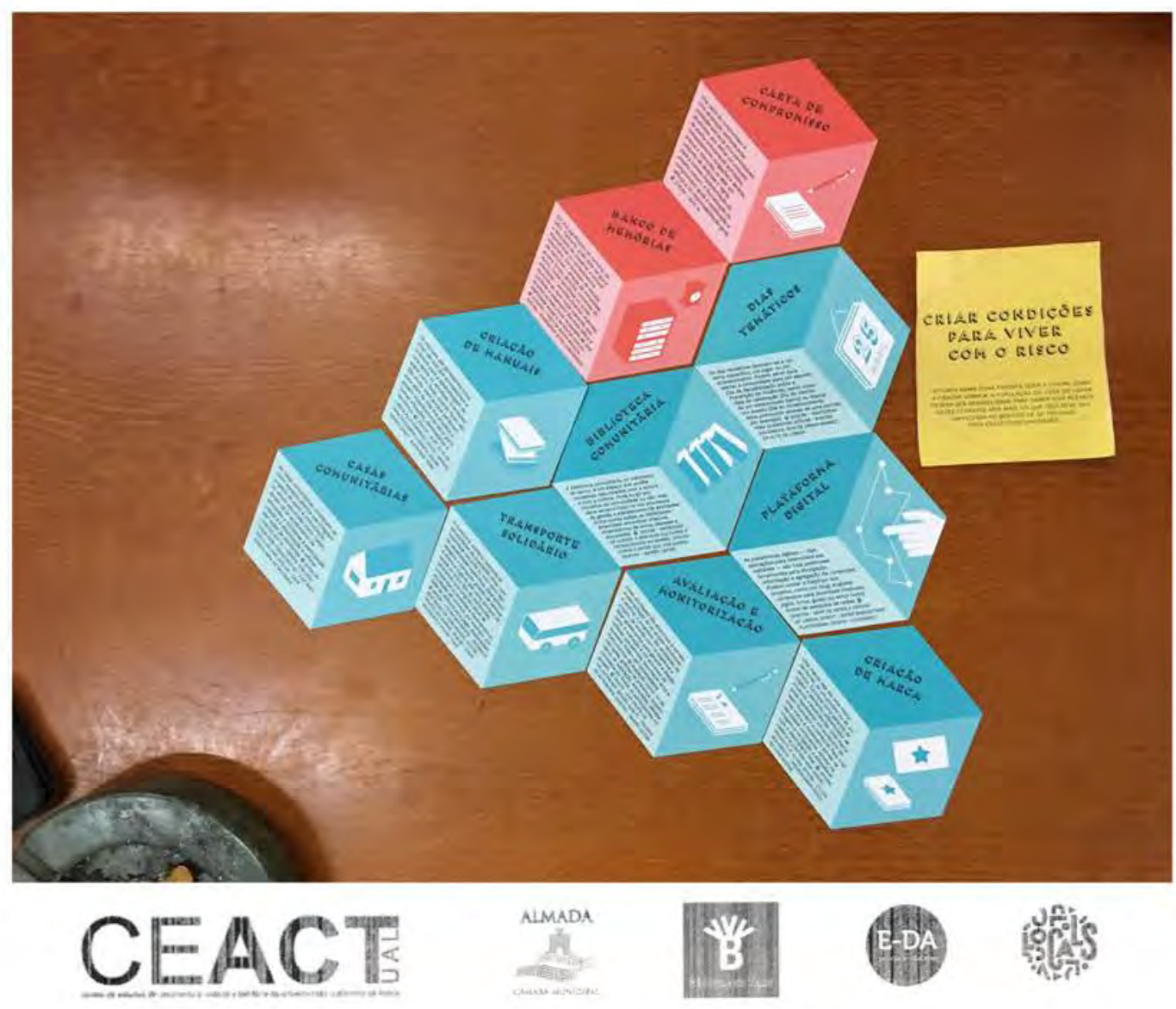
projeco'lleasulorfiar

Ficha de Proieto

1. Nome: $3 R$ - Ade in, os auntomivess, Ricupenar

2. Metas: as ruas, Recuss pane 5

3. Rccursọ necessátios

vecolle de Lixs

a) Rexutheis Himsmen:

Somk affyens, himprz, dowalas, Jovers

o) Rccursen zisicos

pue podian colasion

4. T'empo de Lrecusto

5. Benefirtitriog

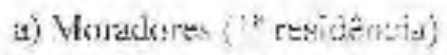

bj Morado ed (2' resicencity

c) Visitanx:s:

d) Tuclias:s

6. Parceiron: Jerute, tedes

7. Projeto

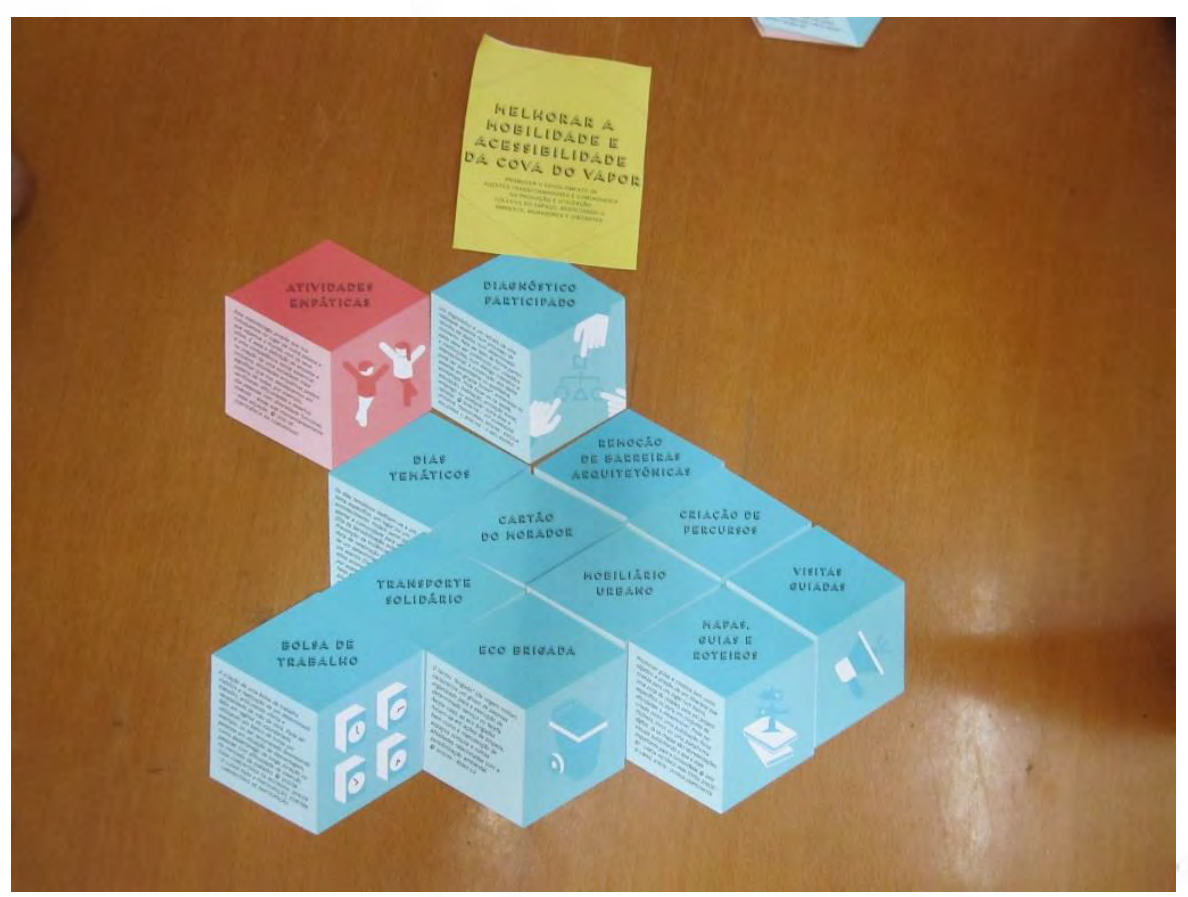

CEACT

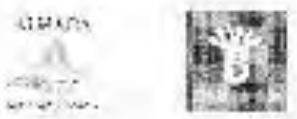

Junh, 2012 
proich Trantorylap:

\section{Ficha de Proieto}

1. Name: VIURR NULHHEF

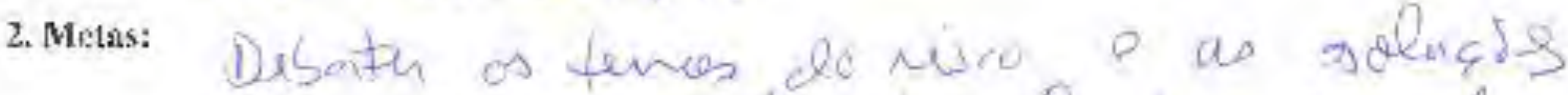

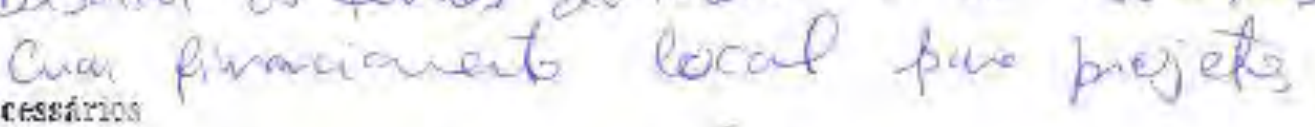

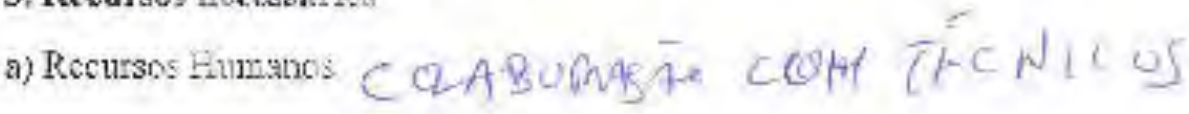

b) Reutswis Tiguns

4. Tempe des Trascuction

\section{Benefietrios:}

a) Moradores (1' rosichent)

b) Moradores (2: resiticuein)

c) Visitante:

di Fondias

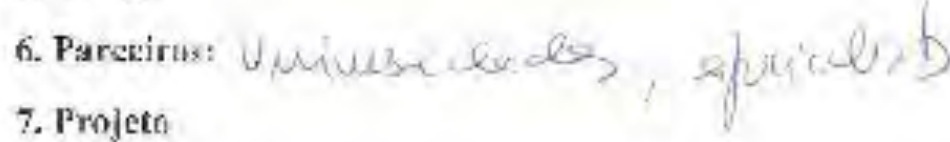

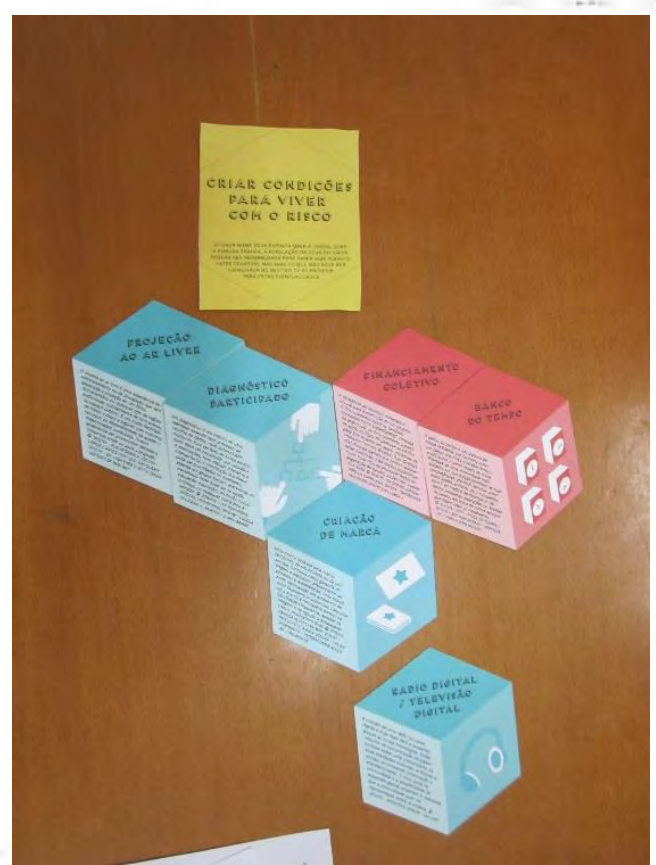


prujeco 'Trazsformin

\section{Ficha de Proiets}

1. Nome: AMtR D AMPIET?

2. Metas: PRTEGER A DUNA

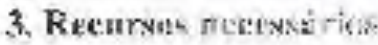

a) Recars: Thamans.

\section{TODA A COMUNIDADE / VAAAAS GeDASDES}

bj Recuesos $\perp \cdot$ latzos DPFISAS DE FORA

4. Tempo de linesuças

5. Beneficing

$$
1 \text { wis / ane }
$$

a) Mondente "residestizi

b) Morature: (2 lositesecis?

e) Visitante.

d) Tod: 25

desto, savit

\section{Parceiros:}

\section{Projete}

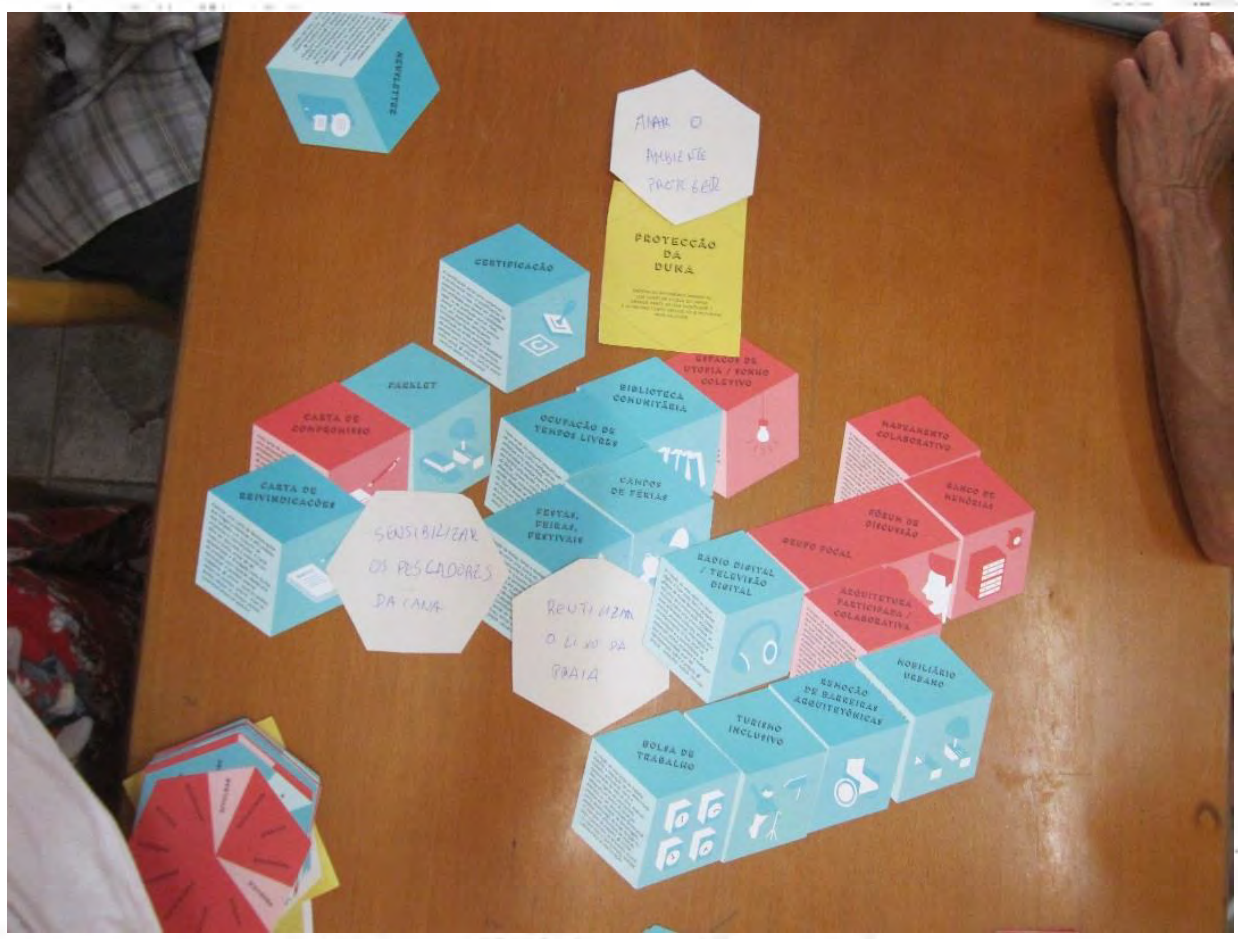

